\title{
Post-obduction evolution of New Caledonia
}

\author{
Sevin B. ${ }^{1}$, Maurizot P. ${ }^{1,{ }^{*}}$, Cluzel D. ${ }^{2}$, Tournadour Elsa ${ }^{1,3}{ }^{3}$, Etienne S. ${ }^{1}$, Folcher N. ${ }^{2}$, Jeanpert J. ${ }^{1}$,
} Collot Julien ${ }^{1}$, Iseppi M. ${ }^{1,4}$, Meffre S. ${ }^{5}$, Patriat Martin ${ }^{1,6}$

${ }^{1}$ Service Géologique de Nouvelle-Calédonie (New Caledonia Geological Survey), BP M2, 98849

Nouméa, New Caledonia

2 University of New Caledonia, ISEA-EA 7484, BP R4, 98851 Nouméa, New Caledonia

${ }^{3}$ ADECAL Technopole, ZoNéCo Research Program, 98845 Nouméa, New Caledonia

${ }^{4}$ BRGM, Antenne Nouvelle-Calédonie 1 ter rue E. Unger, Vallée du Tir - BP 56, 98845 Nouméa

Cedex, New Caledonia

5 University of Tasmania, Private Bag 79, Hobart 7001, Australia

${ }^{6}$ Ifremer, UR Géosciences Marines, 29280 Plouzané, France

* Corresponding author : P. Maurizot, email address : pierre.maurizot@gouv.nc

\begin{abstract}
:
The post-obduction formations of Grande Terre, New Caledonia, comprise igneous intrusions, regolith cover, and marine and terrestrial sedimentary rocks. Two restricted Late Oligocene granitoid bodies are intruded into the Peridotite Nappe and its substrate in the south of the island. Thick regolith cover developed over the Peridotite Nappe from the Late Oligocene or earlier. The Népoui Group comprises Late Oligocene-Early Miocene mixed marine carbonate and siliciclastic deposits. It mainly reworks the Peridotite Nappe and its regolith cover. Its development pattern is mainly controlled by tectonic uplift and subsidence. The Gwa N'Doro Formation on the eastern coast and the Fluvio-lacustrine Formation in the south are remnants of the Miocene-Present river network. Offshore, thick Oligocene to Neogene sedimentary successions are imaged by seismic surveys on the margins of Grande Terre, although these successions have not been drilled and remain undated. Several dredges have recovered shallow Miocene sedimentary rocks, indicating substantial Neogene subsidence. Quaternary formations are represented inland by aeolianite, vertisols and calcrete and offshore by the large barrier reef-lagoon complex, the onset of which is dated at c. $400 \mathrm{ka}$. This chapter discusses the different models proposed for the postobduction evolution of Grand Terre.
\end{abstract}


Chapter 7 Post obduction evolution 1

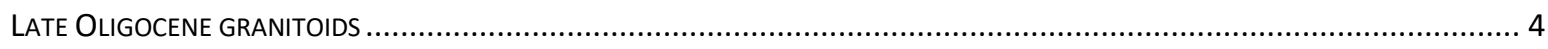

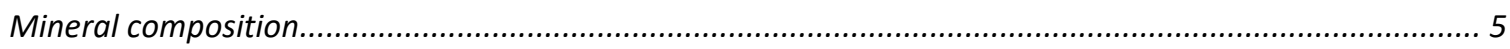

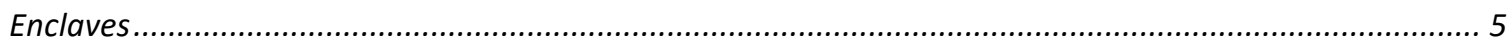

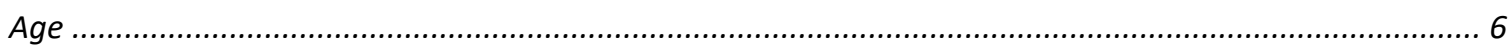

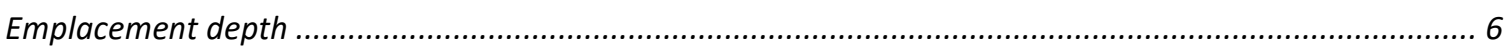

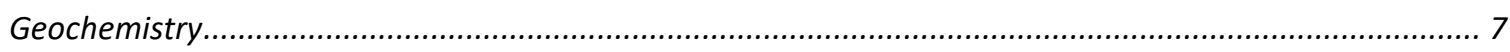

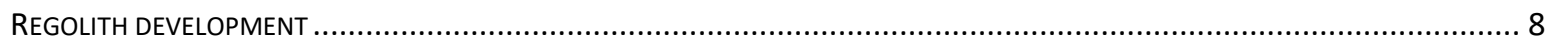

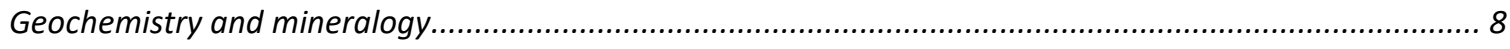

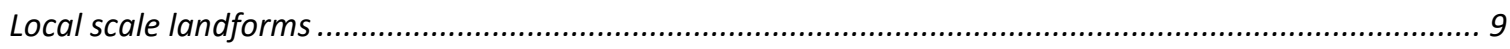

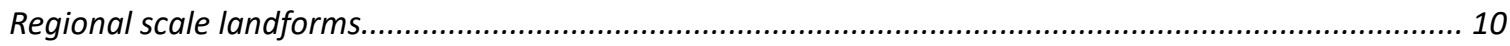

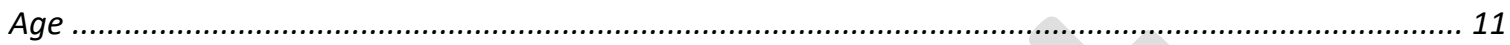

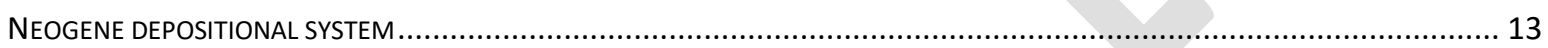

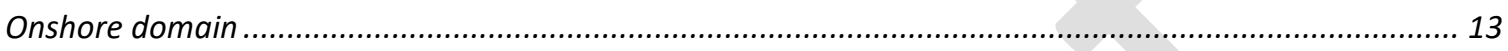

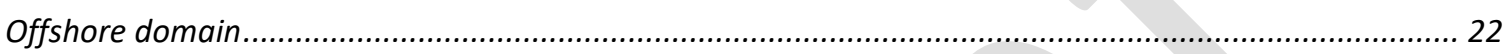

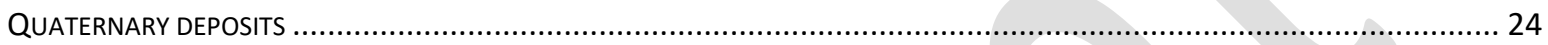

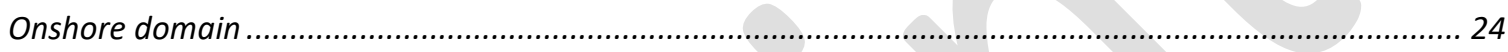

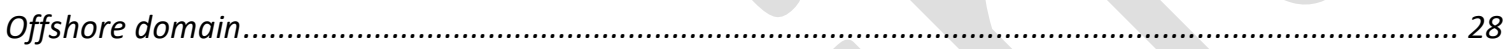

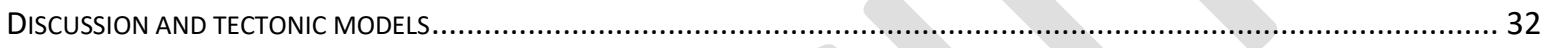

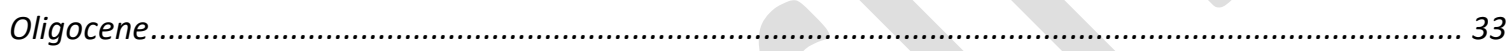

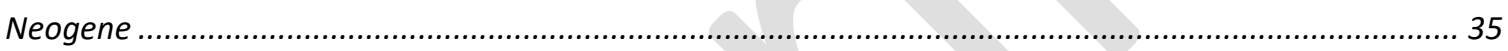

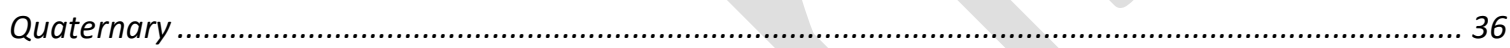

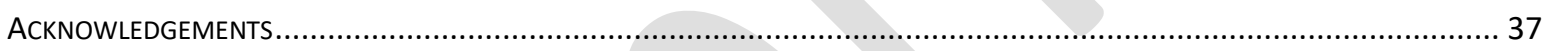

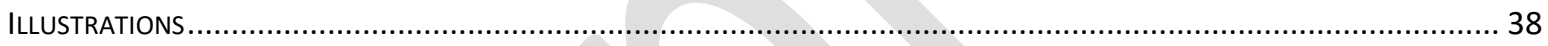

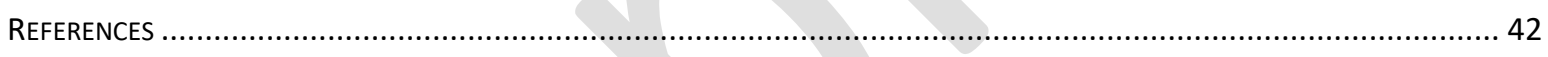


During Eocene convergence, several allochthonous thrust nappe sheets were emplaced over the Norfolk Ridge autochthonous continental basement (cf. chapter 3, this memoir) and its cover (cf. chapter 4, this memoir). Following the cessation of Eocene subduction and obduction tectonics, New Caledonia, the Norfolk Ridge and Loyalty Ridge (cf. chapter 6, this memoir) all became located in an intra-Australian plate setting along and near the northeast edge of Zealandia. On the main island (Grande Terre), the Peridotite Nappe (cf. chapter 5, this memoir) which represents $1 / 3$ of the surface of New Caledonia is located at top of this allochthonous pile, and occupies a dominant topographic situation. Consequently it has been, and is still, exposed to weathering, and erosion.

Except for the extensive regolith which covers almost all formations $\left(2200 \mathrm{~km}^{2}\right.$ out of Grand Terre's $18000 \mathrm{~km}^{2}$ ), the post-obduction (Oligocene to Present) geological record is represented by a variety of disparate and scattered units including small plutons, and terrestrial or marine sedimentary deposits $\left(<50 \mathrm{~km}^{2}\right.$, Fig.1). The exposed peridotites contain more reactive and soluble minerals than other lithologies (Thomas 1994) and are consequently covered by thick laterites. Peridotite-derived materials, both weathered and unweathered, are widespread in the post-obduction deposits (Sevin 2014). Offshore, sedimentary deposits are mainly imaged by seismic survey, and only rarely drilled or dredged.

There are many challenging issues when trying to unravel past tectonic- and climatic- events in New Caledonia with such fragmentary preservation. Onland, characterizing and dating regolith, and terrestrial sediments, all saturated with iron oxy-hydroxides, depleted in radiogenic elements, and lacking of fossils of stratigraphic value, are major problems. Offshore, rocks are partly concealed beneath the lagoon and/or lie in the deep oceanic domain.

This chapter consists of a critical review of published data dealing with post-obduction geological units and events around Grande Terre. These units will be addressed in approximate age order. Whenever unpublished information is newly presented it is referred to as "this work". New geochronological data on Late Oligocene granitoids are presented separately in a supplementary document. The emphasis is on the onland and nearshore record. Post-obduction formations of the offshore Loyalty Ridge are addressed in chapter 6 , this memoir. The regolith section is mainly focused on ultramafic rocks and their exceptional regolith development (cf. chapter 9, this memoir).

\section{Late Oligocene granitoids}

In the south of Grande Terre, two km-size plutons (Saint Louis and Koum-Borindi) intrude both the Peridotite Nappe and its autochthonous substrate (Fig. 2), thus post-dating obduction-related thrusting of the Peridotite Nappe. Saint Louis and Koum plutons display roughly elliptical shapes and are surrounded by a number of metre to decametre-thick dykes. In the vicinity of the Saint Louis pluton, a number of granodiorite and rhyodacite dykes also crosscut peridotites and Late Cretaceous to Eocene autochthonous rocks, at distances of up to $6 \mathrm{~km}$ from the main igneous body (e.g. Saint Louis, Fig. 2c).

The two main intrusive bodies are located near the base of the Peridotite Nappe, which probably formed a screen that hindered further magma ascent. Within the Peridotite Nappe, granitoids are associated with extensive zones of silicification and carbonatisation, which have resulted in the occurrence of carbonated peridotites (listwanites, cf. chapter 9, this memoir, and references therein). Listwanites also form important vein arrays away from plutons, commonly in the serpentinised sole of the Peridotite Nappe (Fig. 2b, c). Both granitoids and listwanites host disseminated sulphides and small 
orebodies characterized by an $\mathrm{As}, \mathrm{Au}, \mathrm{Sb}, \mathrm{Hg}, \mathrm{W}$, Mo epithermal type association (chapter 9, this memoir). Saint Louis $\mathrm{Au}, \mathrm{As}, \mathrm{Mo}, \mathrm{W}$ mineralization and associated alteration can be referred to typical plutonic porphyry gold deposit model.s Granitoids and listwanites are present only in the Massif du Sud and its east coast continuation, and have never been found in other ultramafic units located farther northwest. The occurrence of listwanite (e.g., near Nakety or Koum, on the east coast) separate from known granitoid outcrops suggests that other concealed intrusive bodies may exist at depth.

\section{Mineral composition}

The main Saint Louis intrusive rocks are homogeneous medium-grained, equigranular granodiorite comprising plagioclase, $\mathrm{K}$-feldspar, quartz, biotite and amphibole as major minerals, and accessory zircon, apatite, opaque oxides, and titanite. Actinolite, chlorite, chloritoid, calcite, muscovite, and epidote appear as alteration products. Plagioclase is the dominant phase (40-50\% in volume), and occurs as sub-euhedral to anhedral zoned crystals of oligoclase (corroded cores) and albite (rims) along with late albite crystals. Plagioclase has crystallized early, synchronously with biotite, which appears as euhedral prisms and smaller flakes. Amphibole has crystallized later, usually as sub-euhedral to anhedral poikilitic crystals with biotite, plagioclase, quartz and opaque inclusions, probably replacing augite, occasionally present as relicts. Amphibole grains are in part pseudomorphs of secondary actinolite-hornblende after magmatic magnesio-hornblende. K-feldspar is anhedral and has crystallized very late, in association with interstitial quartz. Intimate association of chloritoid and chlorite results from biotite or amphibole alteration. Secondary muscovite derives from plagioclase. Calcite develops in fractured amphibole and plagioclase grains possibly resulting from late hydrothermal alteration with high $\mathrm{fCO}_{2}$. Some titanite is probably of primary origin but mostly seems to be a product of biotite alteration (Cluzel et al. 2005).

Microgranodiorite dykes and enclaves have the same composition as the main facies with plagioclase, biotite, and amphibole phenocrysts. Dykes are generally fine-grained, and locally porphyritic. The dykes contain some biotite schlieren and numerous clinopyroxene relicts are preserved in amphibole cores.

Koum-Borindi granitoids (Fig. 3) are more leucocratic (quartz-monzonite to granite) than St Louis and contain minor biotite and rare amphibole. Euhedral sodic plagioclase $\left(\mathrm{An}_{23}-\mathrm{An}_{03}\right)$ is the major mineral in coarse grained rocks and also appears as phenocrysts in finer-grained facies. K-feldspar ( $\left.\mathrm{Or}_{87}-\mathrm{Or}_{97}\right)$ is generally anhedral and perthitic and forms oikocrysts enclosing plagioclase, quartz and biotite grains. Quartz is interstitial except in porphyritic subvolcanic dykes where it appears as corroded phenocrysts. Biotite is not very abundant. Magnetite, titanite, apatite and allanite are accessory minerals. Chlorite and muscovite may be locally abundant as alteration products.

\section{Enclaves}

Both plutons contain a number of enclaves. Sedimentary xenoliths dragged up from the basement are rare and only represented in Saint Louis granodiorite by Palaeocene limestone locally transformed to garnet- and scheelite-bearing skarn (cf. chapter 9, this memoir, and references therein). Scarce inherited zircons (see U-Pb dating below) indicate that some fragments of basement rocks have been assimilated. Most magmatic enclaves are finer-grained and display the same mineral and geochemical composition as the main body; they probably represent early co-magmatic dykes cannibalized by the main intrusion. The occurrence of xenoliths with a clearly distinct composition merits consideration because they may provide some evidence about magma forming processes. Syeno-diorite xenolith SL3 
from Saint Louis has been considered as more primitive than the average granodiorite host and as such, has been taken as an end-member of the differentiation trend; however, this view does not account for the trace element composition as discussed in the geochemistry section below.

A granulite-facies xenolith (hercynite, garnet, Ba-rich plagioclase, Ti-rich biotite) has been found in the Koum-Borindi pluton. It shares some geochemical, isotopic features, and U-Pb zircon age with the enclosing rock, and indicates that magma underplating occurred at depth of c. $30 \mathrm{~km}$, (Paquette \& Cluzel 2006).

Age

Due to the absence of unconformable sediments, there is no direct stratigraphic constraint on the age of intrusion, which therefore only relies on geochronology. Early dating of Saint Louis Granodiorite reported Miocene-Oligocene apparent/cooling ages, ranging from c. $20 \mathrm{Ma}$ (Black et al. 1994), $24.7 \pm$ $0.7 \mathrm{Ma}$ (K/Ar on biotite; Guillon, 1975) to $32 \pm 3 \mathrm{Ma}$ (Rb/Sr on biotite; Guillon, 1975). These time constraints have been refined by U-Pb method on zircon, which has given Late Oligocene ages for Saint Louis granodiorite (27.4 $\pm 0.2 \mathrm{Ma}$ ) and Koum granite (24.3 $\pm 0.1 \mathrm{Ma}$, Paquette and Cluzel, 2006). Both plutons yielded scarce inherited Palaeozoic zircon cores possibly coming from assimilation of basement xenoliths (Paquette \& Cluzel 2006). New laser-ablation inductively-coupled plasma to mass spectrometry (LA-ICP-MS) U-Pb zircon ages have been obtained (this work) on two micro-granodiorite dykes located near Tina, a few $\mathrm{km}$ to the southwest of Saint Louis pluton; both are slightly younger than the main granodiorite body ( $24.3 \pm 0.4$ and $24.5 \pm 0.2 \mathrm{Ma}$; Fig. 4 , and supplementary document).

\section{Emplacement depth}

The occurrence of subvolcanic dykes inside and outside the plutons, and fine-grained enclaves, suggest emplacement at shallow level. However, precise thermo-barometric estimation is hindered by hydrothermal alteration which, as noted above, has resulted in secondary mineral phases. However, a P-T estimate has been attempted on selected microprobe mineral analyses of Saint Louis granodiorite (Montjoie 1999) by using hornblende-plagioclase geothermobarometry (Anderson \& Smith 1995; Blundy \& Holland 1990; Holland \& Blundy 1994; Schmidt 1992) and Ti-in-hornblende geothermometry (Otten 1984). The unpublished results indicate a crystallization pressure of $0.2-0.3 \mathrm{kbar}$ at $600-630^{\circ} \mathrm{C}$; thus a maximum emplacement depth of c. $1 \mathrm{~km}$. This estimate is consistent with the occurrence of porphyry-type Mo-Au mineralization, which generally occurs at depths of $<1.5 \mathrm{~km}$ (Seedorff et al. 2005, and chapter 9 , this memoir). Thermochronology by fission track and (U-Th)/He methods on apatite and zircon on five samples from both granitoids yielded scattered results between 13 to $36 \mathrm{Ma}$, with a cluster at about 20-28 Ma (Bailly et al. 2014). The latter ages are close to the U-Pb magmatic ages (see below) of the rocks. They are also close to the weathering age determined by K/Ar or Ar/Ar methods (see Regolith dating, below). The isotopic composition of oxygen (relative to Standard Mean Ocean Water or SMOW) in primary quartz veins $\left(\delta^{18} \mathrm{O}=13-16\right)$ from Grosses Gouttes stock (Saint Louis) is typical of hydrothermal origin; however, quartz overgrowths in the same veins yield supergene signatures $\left(\delta^{18} \mathrm{O}=\right.$ c. 21$)$; similarly, $\mathrm{Ge} \mathrm{Al}$ and $\mathrm{Mg}$ contents in quartz and fluid inclusions suggest twostage quartz crystallization and mixing of meteoric and magmatic waters at shallow depth (Martin 2011). Altogether, these data suggest shallow emplacement and fast cooling and exhumation to the surface. 


\section{Geochemistry}

The Saint Louis massif is a homogeneous medium-K calc-alkaline granodiorite; in contrast, KoumBorindi granitoids display more evolved and diverse high-K calc-alkaline diorite to granite compositions (Fig. 5a).

Expanded trace elements and REE patterns are very similar for the main Saint Louis granodiorite body as well as its dykes and enclaves (with the exception of the diorite xenolith SL3), a feature that contrasts with the diversity of Koum-Borindi rocks, especially in terms of HREE contents, which show normal and low-HREE types (Fig. 5b).

Saint Louis rocks display a moderate negative $\mathrm{Nb}$ anomaly with respect to $\operatorname{LREE}\left(0.36<(\mathrm{Nb} / \mathrm{La})_{\mathrm{n}}<0.55\right)$; in contrast, Koum-Borindi rocks display a lesser anomaly $\left(0.86<(\mathrm{Nb} / \mathrm{La})_{\mathrm{n}}<3.2\right)$. Nb depletion is usual in magmas generated by melting of a metasomatized mantle wedge (Pearce 1982; Sun \& McDonough 1989); on the Nb vs. $\mathrm{Y}$ and Rb vs. Nb+Y discriminant diagrams of Pearce et al. (1984), Saint Louis and Koum-Borindi granitoids plot in the field of volcanic-arc granites (Fig. $5 \mathrm{c}$ and d); therefore, Saint Louis granitoids are likely due to the melting of a "normal" supra-subduction source. Similarly, almost all the samples plot in the field of volcanic-arc magmas on the Hf/3-Th-Ta diagram (Fig. $5 \mathrm{~h}$ ) of Vermeesch (2006). Saint Louis granitoids plot in a very restricted domain, confirming the homogeneity of this set; in contrast, Koum-Borindi granitoids delineate a trend between continent-based volcanic-arc and intraplate end-members. Relatively moderate contents in highly incompatible elements $\mathrm{K}, \mathrm{Rb}$ and Th suggest only minor contribution of subducted sediments or continental crust, which is confirmed by isotopic data (see below).

Relatively higher $\mathrm{Nb}$ contents $(\mathrm{Nb}>18 \mathrm{ppm})$ and a lesser $\mathrm{Nb}$ anomaly $((\mathrm{La} / \mathrm{Nb}) \mathrm{n}>0.9)$ are not correlated with silica content except for the higher values $\left(\mathrm{SiO}_{2}>72 \mathrm{wt} \%\right.$; Fig. $\left.5 \mathrm{e}\right)$ and suggest that a lesser negative $\mathrm{Nb}$ anomaly in Koum-Borindi granitoids does not depend on differentiation only, and is at least partly a source feature.

$\mathrm{Sr}$ and $\mathrm{Nd}$ isotopic compositions of both plutons are somewhat similar; however, some small differences may be significant. $\mathrm{Nd}$ isotopic ratios of the Saint Louis granodiorite $\left(3.4<\varepsilon \mathrm{Nd}_{27 \mathrm{Ma}}<4.8\right)$, and of the Koum-Borindi massif $\left(4.8<\varepsilon \operatorname{Nd}_{24 \mathrm{Ma}}<5.2\right)$ plot in the moderately enriched domain of the mantle array. With respect to $\varepsilon N d$ Koum-Borindi samples are less "enriched" and less variable than Saint Louis samples, independently of differentiation. Sr isotopic ratios do not show evidence for contamination by radiogenic strontium (Fig. 5f). Therefore, in spite of the occurrence of rare inherited Precambrian zircon cores (Paquette and Cluzel, 2006), Oligocene granitoids do not seem to have been significantly contaminated by crustal material, at least of any antiquity.

The limited but significant range of $\varepsilon N d$ ratios of Saint Louis rocks at relatively constant $(\mathrm{Nb} / \mathrm{La})_{n}$ may be related to an isotopically heterogeneous mantle source, or to magma mixing, as suggested by disequilibrium textures. The lead isotopic ratios are also in a very narrow range $\left(38.621<{ }^{208} \mathrm{~Pb} /{ }^{204} \mathrm{~Pb}<\right.$ 38.670; $15.587<{ }^{207} \mathrm{~Pb} /{ }^{204} \mathrm{~Pb}<15.601 ; 18.819<{ }^{206} \mathrm{~Pb} /{ }^{204} \mathrm{~Pb}<18.896$; Cluzel et al, 2005; not presented here), and fully consistent with Sr-Nd isotopic data. All isotope data indicate moderately depleted sources for Saint Louis and Koum-Borindi plutons, which very much resemble that of "intra-oceanic" volcanic-arc magmas (i.e. Tonga-Kermadec, Othman et al. 1989) with minor or no influence of cratonic continental crust or subducted sediments. 
These weak but significant differences in ages and trace element contents between Saint Louis and Koum granitoids and inferences on geodynamic evolution are discussed in the final section of this chapter.

\section{Regolith development}

During the Late Oligocene to Present, the northward drift of the Australian plate (Müller et al. 2000, chapter 2, this memoir, and see below), brought New Caledonia to low latitudes, with warm and wet climate conditions. Consequently, thick regolith developed on all emergent surfaces, particularly on chemically reactive peridotites.

In New Caledonia, there has been much study of regolith development on the Peridotite Nappe due to the economic importance of associated nickel deposits (cf. chapter 10, this memoir). In contrast, hardly any attention has been paid to regoliths developed on other lithologies, where weathering profiles are nevertheless present, although much thinner (typically c. $20 \%$ of that on peridotites). Due to the lack of studies, these latter profiles will not be addressed here.

Olivine is a silicate mineral that is one of the most vulnerable to weathering (cf. chapter 10 , this memoir, and references therein). Peridotites are consequently covered by a thick lateritic cover, commonly reaching $50 \mathrm{~m}$. A typical complete profile is shown in Fig. 6. From top to base it typically comprises:

- Ferricrete (0 to c. $10 \mathrm{~m}$ thick) which corresponds to the zone of seasonal oscillation of the subsurface water table, where alternating saturated and unsaturated conditions precipitate iron oxy-hydroxides.

- Laterite s.s. (or plasmic zone) with a transition zone, c. $10 \mathrm{~m}$ thick in which all primary rock textures have been erased;

- Saprolite, up to c. $50 \mathrm{~m}$ thick, where inherited bedrock structure is retained but transformation to a soft secondary material is complete, indicating major mass loss;

- Saprock (composed of at least $20 \%$ of weathered rock), 0 to c. 80 m thick, in which concentric spheroidal weathering preserves blocks or boulders of fresh rock (corestones);

Root casts made of Fe or $\mathrm{Mn}(+\mathrm{Co})$ oxy-hydroxides are common and are mainly seen at the base of the saprolite (transition zone) or in the ferricrete.

\section{Geochemistry and mineralogy}

There is a considerable geochemical contrast between the fresh rock and its weathered equivalent, which is best expressed by changes at the so-called Mg discontinuity (Freyssinet et al. 2005) or transition zone (Fig. 6). Weathering of peridotite leaches soluble elements, such as $\mathrm{Mg}, \mathrm{Ca}$, $\mathrm{Si}$, and in contrast, accumulates $\mathrm{Fe}, \mathrm{Al}$, and to a lesser extent $\mathrm{Mn}, \mathrm{Ni}, \mathrm{Co}$, and $\mathrm{Cr}$ (Fig. $6 \mathrm{c}$ ). The subtractive process leaves a strong residue creating the laterite profile, which mainly consists of Fe oxy-hydroxides. Due to low content and mobility of Al in peridotite ( $\mathrm{Al}$ is essentially contained in chromium spinel, a mineral very resistant to weathering), very few clay minerals form. Silica precipitates in a variety of poorly crystalline hydrous phases such as opal and garnierite that host nickel (cf. chapter 10, this memoir).

At the grain scale (Fig. 6d), weathering preferentially dissolves olivine then pyroxene, and finally the various serpentines which are the most resistant. Through this progressive process, the serpentine network contributes to the cohesion of the saprock in which the volume is preserved but loss of mass 
is significant (Trescases 1975). In the saprolite overlying the fresh rock, minerals, textures, fractures, and dykes are still identifiable as ghosts in an oxidised matrix. Hydroplastic deformation and compaction features are typical. The progressive dissolution of serpentine leads to a general compaction. Unlike typical saprolite on Si- and Al-rich parent rocks (Scott \& Pain 2009; Taylor \& Eggleton 2001), volume is therefore not preserved in the saprolite on ultramafic parent rocks. As a consequence, ghost structures are considerably distorted. Ptygmatic folds resulting from the gravitational packing down of formerly-vertical structures are observed, as is general flattening and shallowing of layering. In some cases, steeply-dipping structures of the bedrock are plastically warped over fresh rock cores (Fig. 7).

\section{Local scale landforms}

In New Caledonia, peridotites present extensive evidence of karstic development from the outcrop scale to that of regional landscapes. Lapies (karren), sinkholes, blind valleys, and disappearing streams are common features, and Grand Terre is a reference for peridotite karstic features (Baltzer et al. 1967; Genna et al. 2005a; Genna et al. 2005a b; Jeanpert et al. 2014; Jeanpert et al. 2016; Latham 1977, 1986; Sevin 2014; Trescases 1975; Wirthmann 1965). New Caledonia can be compared with other countries with similar geology and tropical climate e.g. Cuba (Acevedo-Gonzales 1967; Acevedo \& Gutierrez 1976; Nunez et al. 1967; Pacheco et al. 2002; Pacheco et al. 2003), Indonesia (Hope 2001, 2015), Papua New Guinea (Loffler 1978), Philippines (Marker et al. 1991), Greece (Riedl \& Papadopoulos-Vrynioti 2001).

Whereas limestones worldwide can be subject to almost $100 \%$ dissolution leading to extensive cave systems, weathering of peridotite leaves an important insoluble in situ residue of laterite that generally clogs voids and gives way to a few endo-karst conduits. In New Caledonia, such dissolution features on ultrabasic rocks are termed pseudo-karstic (Jeanpert et al. 2014, 2016; Trescases 1975).

Aquifers can set up in the peridotite protolith because the fracture network is dense and ubiquitous and provides fracture permeability. Through this network, groundwater circulation is favoured at the expense of organized surface drainage. Instead of generating a surficial hydrographic network, this process tends to form isolated, often endorheic, cells that enlarge into basins. These areas are covered by thick laterite, capped by resistant ferricrete, and surrounded by residual ridges of unweathered peridotite. Weathering of peridotite to laterite results in a volume loss of 85 to $90 \%$. Thus, a $1 \mathrm{~m}$-thick laterite results from the resorption of 6 to $9 \mathrm{~m}$ of peridotite (Fritsch 2012; Fritsch et al. 2014). Reported rates of weathering are in the range of 10 to $50 \mathrm{~m} / \mathrm{My}$ (Freyssinet et al. 2005; Trescases 1973) so that a $50 \mathrm{~m}$ thick lateritic profile may form in 1 to $5 \mathrm{Ma}$ and may represent up to $300 \mathrm{~m}$ of transformed bedrock, in steady state conditions without erosion. The weathering process progresses downward, smoothing and softening the underlying protolith whose surface becomes increasingly flat and covered by thick laterite.

Ferricrete surfaces are studded with closed depressions, sinkholes, ponds, lakes, and swamps, where the water table surface is often exposed. Sinkholes (Fig. 8) result from downward entrainment of laterite into the underlying karstic network, leading to collapse of the ferricrete roof. A survey of c. 10 000 sinkholes or closed depressions has been identified by both field data collection and morphometric analysis on a digital terrane model in the large ferricrete surfaces of the south of Massif du Sud (Jeanpert et al. 2014; Jeanpert et al. 2016). Sinkholes are commonly elongated and aligned, revealing the fracture-controlled underground drainage. The weathering front may locally drop very deeply 
(more than $100 \mathrm{~m}$ ) due to preferential water circulation in narrow fault gouges. Sinkholes of various sizes may overlap or be nested. Active sinkholes are deep and funnel shaped, whereas inactive ones are shallow and flat, filled and clogged with sediments. They are transient features that fluctuate between an active, free draining state to an inactive, clogged state. Although their density is higher in basins, sinkholes are also present on plateaux and more elevated areas.

Weathering profiles harbour multi-layered aquifers (Jeanpert et al. 2016; Join et al. 2005, Fig. 6e) with contrasting properties. The topmost ferricrete is a surficial aquifer which favours infiltration. The semipermeable saprolite and laterite are aquitards. The saprock is the main aquifer. The fractured fresh peridotite has a very low hydraulic conductivity. This general scheme prevails except where karstic conduits in the bed rock connect underground and surface levels through active sinkholes. The weathering profile is therefore a perched aquifer that retains water and allows weathering to be maintained. Weathering is therefore a self-sustaining process that lasts as long as there is a substantial and coherent regolith surface able to preserve water table activity. In order to maintain weathering, there must be active water circulation which subtracts elements by chemical solution or particle transport. This cannot be achieved without an intra-aquifer gradient which, in turn, is partly controlled by raising or lowering of sea level.

Therefore, there is a tradeoff between the rate of chemical weathering (deepening of the weathering front) and the rate of uplift (or relative sea level fall), in order to maintain efficient drainage. Where the rate of uplift is much higher than the rate of weathering, mechanical erosion will easily destroy the soft regolith material. Where subsidence prevails, internal drainage will be impeded, and the profiles will no longer evolve. Between these two extreme situations, a range of weathering system paths is possible.

\section{Regional scale landforms}

Stepped tracts of planar surfaces, mantled by lateritic profiles, are commonly observed throughout the island on both peridotite and non-peridotite parent rock (Fig. 9). These planation surface remnants are interpreted as resulting from an alternating succession of periods during which stability and weathering were dominant and periods during which epeirogenic movements prevailed (Avias 1969; Chardon \& Chevillotte 2006a; Chevillotte 2005; Chevillotte et al. 2006; Chevillotte et al. 2004, 2005; Lagabrielle \& Chauvet 2008; Lagabrielle et al. 2005; Latham 1977, 1986; Sevin 2014; Sevin et al. 2014; Trescases 1975, 1973; Wirthmann 1965).

The improvement of topographic data over the decades has enabled an increasing number of stepped planation surfaces to be distinguished. A single initial surface was proposed by Davis (1925), on the basis of observations from a boat with the help of the first and rough small-scale maps. Later, three stepped surfaces were recognised (Trescases 1975, 1973; Wirthmann 1965, 1970), and then six using conventional 1:50 000 scale topographic maps (Latham 1986). At present, eight surfaces have been identified with the help of modern $10 \mathrm{~m}$ cell size Digital Elevation Models (DEMs, http://www.georep.nc/article imagerie.php, and Chevillotte et al. 2006).

At a regional scale, the Bélep islands, Grande Terre, and Ile des Pins, display a conspicuous doublyplunging (in longitudinal and transverse senses) upwarp (Fig. 10). This was first interpreted as the result of the deformation of a primitive and single peneplain (Davis 1899; Davis 1925). The large upwarp surface, although locally uneven and disrupted by some faults, affects major regolith surfaces shaped 
on both the basement and the Peridotite Nappe, suggesting a general post-obduction phenomenon of regional importance.

The longitudinal (along-island) upwarp shape is marked at both ends (Iles Béleps, and lle des Pins) by the plunging below sea level (BSL) of the Peridotite Nappe capped by thick ferricrete surfaces. The shorter-wavelength transverse (across-island) upwarp is asymmetric. In the area of the Koniambo and Kopéto-Boulinda massifs, the highest (oldest?) regolith surfaces plunge gradually from c. $900 \mathrm{~m}$ on top of the peridotite massifs down to sea level on the southwest coast, extending into the tabular Miocene Népoui Group deposits (see next section "Neogene depositional system"). Although there are obvious disruptions and slope changes, this composite surface dips gently at 2 to $5^{\circ}$ to the southwest. This suggests a former association between highest regolith surfaces and Miocene deposits. On the northeast side of Grand Terre, the transverse upwarp slopes are much steeper than on the southwest coast.

Regolith surfaces are present in a wide variety of elevations and landforms. On the basement they are commonly represented by multi-convex smoothed surfaces of large lateral extent. Such surfaces are exposed on the axis of the Central Chain in the area of plateaux from Houaillou and Tango. The latter plateau dips gently to the northeast.

On the peridotite massifs, planation surfaces are covered by continuous thick laterite, in turn capped by ferricrete. Different stages of landscape formation are observed from basins, to inverted plateaux, to dissected steep mountains, interpreted as resulting from progressive uplift and erosion (Sevin 2014, Trescases 1975,1973$)$. This process gradually uncovers the underlying peridotite bedrock and, with increasing altitude and subsequent deepening of the drainage network, reveals its fracture fields. Some stages of this progressive evolution in the south of Massif du Sud are presented in Fig. 11, in which the NW-SE and NE-SW fracture fields of this area are progressively revealed. In the Goro nickel deposit area (Fig. 11-1, cf. chapter 10, this memoir) the ferricrete surface is enclosed in a basin surrounded by crests of fresh peridotite. The ferricrete surface is studded by depressions, swamps, and sinkholes, some of them filled with lakes. At the edge of the ferricrete plateau, sinkholes become deeper, funnel shaped, and are gradually captured then connected to the upstream part of the rivers by headward backstepping and regressive erosion. In the Unia area (Fig. 11-2), a consistent ferricrete plateau is preserved, surrounded by deep valleys. This is a typical case of a basin inverted to a plateau by uplift and erosion. In the Yaté coastal uplifted area (Fig. 11-3), sinkholes are deep-seated in peridotite bedrock and are surrounded by characteristic circular valley heads. Many rivers disappear into sinkholes and the underlying karst; there is general down-cutting of the relief into rectilinear valley and crest segments revealing the underlying bedrock structure. The end stages are seen in the Pirogues River area (Fig. 11-4), where ferricrete remains in a few places as (non-mappable) accumulations of dismantled blocks. Only laterite cover remains on slopes, and many rectilinear valley and crest segments are the result of the adaptation of the drainage pattern to the underlying bedrock structure.

\section{Age}

Regolith formation is a long process that started soon after obduction. In the basal serpentinite sole of the Peridotite Nappe, magnesite concretions and veins are observed, e.g. at the base of the Koniambo Massif (Quesnel et al. 2016; Quesnel et al. 2013a). Magnesite mainly occurs in kinematically static, cauliflower-shaped concretions. A minority of magnesite occurrences are in sigmoidal tension cracks indicating top-to-the-southwest shearing. Oxygen and carbon isotope compositions point to a 
meteoric origin and suggest that weathering on top of the Peridotite Nappe was already active and provided, through dissolution and per descensum process (migration from top to the bottom), the Mgbearing fluids that were trapped at the basal contact. The occurrence of partially syn-kinematic magnesite veins does not imply that all concretions were formed during obduction ( $34 \mathrm{Ma}$, cf. chapter 5 , this memoir) because in such a case all magnesite occurrences in the basal sole would share the pervasive shear fabrics of the serpentinite host rock. They were more probably formed after obduction during subsequent movements of the West Coast klippes. However, these later events are not well dated.

That weathering of peridotite continues to the present day is shown by several observations: in the Goro area, newly-formed sinkholes have formed across prospecting tracks that are only a few decades old (Jeanpert et al. 2016). On road cuts and in quarries, c. 50 years old, fresh peridotite is commonly covered by a 1 to $10 \mathrm{~mm}$ brown oxidation crust, a feature observed globally (Bucher et al. 2015). More questionable, but noteworthy, is the occurrence of a small fossilised coleopter (Adelium externecostatum, now Cymbeba externecostata (Bates 1873)), within a veinlet of garnierite (Lacroix 1905) of undetermined origin. This insect is endemic to New Caledonia, and the species is still extant, suggesting a recent fossilisation. However, its past age range is not known.

Different direct and indirect dating methods have been tried in order to establish episodes and rates of regolith development (mainly on ultramafic-derived weathering products; Bailly et al. 2014; Quesnel et al. 2012). Sampling for palaeomagnetism has focussed on ferricretes capping the main weathering profiles of the Peridotite Nappe, and also various concretions intercalated in the Miocene and Fluviolacustrine formations. Ferricrete on top of the weathering profiles has been sampled not only because it is a material more suitable for coring and lab processing than the underlying soft laterite, but because, as described above, the underlying part of the weathering profile, is prone to hydro-plastic deformation and compaction that could have disturbed the magnetic signal. The iron-rich and indurated ferricrete forms in the vadose zone, where fluctuations of the water table induce a massive crystallisation of the mineral phases that bear a strong magnetic signal (haematite and goethite). Therefore, the age of magnetic vectors recorded in ferricrete is supposed to represent the age of formation of a planation surface, prior to its demise and abandonment.

Paleomagnetic results can be compared to $5 \mathrm{My}$ intervals along the APWP (Apparent Polar Wander Path) curve of the Australian plate, as New Caledonia has been part of the Australian Plate during Neogene time. Despite an extensive sampling (3800 cores on 23 sites, Fig. 12), the method only produced seven valid results (Prognon et al. 2014a; Prognon et al. 2014b; Quesnel et al. 2012; Quesnel et al. 2008; Quesnel et al. 2015; Quesnel et al. 2013; Quesnel et al. 2011; Ricordel-Prognon et al. 2011; Ricordel-Prognon et al. 2010; Ricordel-Prognon et al. 2013; Sevin 2014; Sevin et al. 2010; Sevin et al. $2012 \mathrm{~b}$ ). On the whole, the inferred ages are in the range 0-25 Ma. In the south of Massif du Sud and at lle des Pins, the full range between 0 and $25 \mathrm{Ma}$ is represented, sometimes at the same site and sub-sites, although there is only one single ferricrete horizon. For example, at Goro, only an age from 25-0 Ma can be proposed because all the poles obtained from the individual sub-sites plot within the 0-25 Ma segment of the reference curve with overlapping confidence circles (Mcfadden \& McElhinny 1988). Notably at Tiébaghi, the mean pole obtained for the 5 sub-sites, plots near the 25 Ma pole of the reference curve; this result is consistent with that of Falvey (1979). The uniform 25 Ma age obtained at Tiébaghi suggests that the ferricrete on this massif represents one single episode and a fossil surface, a feature consistent with its high elevation (500 m). At Goro, the different ages obtained 
from the same and single ferricrete surface, suggest a more complex history, and continuous weathering up to today, an interpretation consistent with its location in a low-elevation area, where weathering is still active. The $25 \mathrm{Ma}$ age (latest Oligocene) shared by the Goro and Tiébaghi sites, represents an episode of extensive weathering and landforming that may correlate with the Late Oligocene Warm Event (Zachos et al. 2001) thermal optimum (Sevin et al. 2012a).

At the unsuccessful sites, e.g. most of the higher surfaces of the West and East coasts, the magnetic signal is dispersed. This may result from incomplete crystallisation of the material, chemical dissolution/recrystallization, mechanical degradation, or any combination of these processes.

In summary, sites datable by palaeomagnetic methods only occur around the edge of Grande Terre where large continuous ferricrete surfaces are exposed (Thiébaghi, Goro, lle des Pins). The absence of magnetically datable ferricrete surfaces towards the middle of the island, (West Coast klippes, and East Coast) may suggest that an early (much-uplifted) ferricrete cover, older than $25 \mathrm{Ma}$, was present in a few places, but became degraded and destroyed, its remnants being incorporated in neo-formed conglomeratic ferricrete (Koniambo, Kopéto-Boulinda, Latham 1977, 1986; Sevin 2014; Sevin et al. 2012b).

The (U-Th)/He dating method has been applied to goethite rhizocretions on 4 samples from Nakety, Boulinda, and Goro areas. The ages (10 measurements) are in the range 0.6 to $5.6 \mathrm{Ma}$, with a majority in the interval 0.6-1.8 Ma. Age differences between core and rind may be as high as $1 \mathrm{Ma}$ but lack a consistent polarity (Bailly et al. 2014). These preliminary results are difficult to interpret and, as such, are not shown in Fig. 12.

$\mathrm{K} / \mathrm{Ar}$ and ${ }^{40} \mathrm{Ar} /{ }^{39} \mathrm{Ar}$ dating of potassium-bearing manganese oxides (cryptomelane) has been attempted (Bailly et al. 2014). None of the 44 samples collected above peridotites contained the appropriate mineralogical phases. Two drillcore samples from the weathered part of the Late Oligocene Saint Louis granite (see above, and chapter 9, this memoir) yielded appropriate mineralogy and seemingly satisfactory K/Ar results. Ages of 18.7+/- $0.6 \mathrm{Ma}$ (at $13 \mathrm{~m}$ depth) and 17.8+/- $0.6 \mathrm{Ma}$ (at $20 \mathrm{~m}$ depth) were obtained on cryptomelane (Bailly et al. 2014). Although the ages overlap within error, the deeper sample has a slightly younger central age than the shallower one, consistent with 'per descensum' weathering. A rate of weathering of c. $7 \mathrm{~m} / \mathrm{My}$ may be compared with the rate derived above for peridotite of 10 to $50 \mathrm{~m} / \mathrm{My}$. The same samples have given composite ${ }^{40} \mathrm{Ar} /{ }^{39} \mathrm{Ar}$ ages respectively centered on $20.0-21.8$ and $13.0-13.7 \mathrm{Ma}$ intervals, corresponding likely to two distinct mineral phases (Bailly et al. 2014). Taken together, K/Ar and Ar/Ar dating broadly indicate a Miocene age of the granite weathering. However, there is no typical regolith surface associated with these granitoids that could be related to a major ferricrete surface of the peridotites.

These results highlight the difficulty in using both direct and indirect dating methods in this environment, due to high mobility of iron for the palaeomagnetism, and depletion in radiogenic isotopes for radiometric methods.

\section{Neogene depositional system}

\section{Onshore domain}

The post-obduction onshore sedimentary deposits of Grande Terre consist of the terrestrial to shallow marine, mixed siliciclastic and carbonate sedimentary rocks of the Népoui Group on the Southwest 
Coast, the siliciclastic deposits of the Gwa N'Doro Formation on the Northeast Coast and the Fluviolacustrine Formation in the south of Massif du Sud. The partly marine Népoui deposits are well dated. In contrast, most of the other terrestrial and dominantly siliciclastic deposits are poorly dated, and their correlation is thus a matter of debate. Although these formations are poorly represented, they are very important for the understanding of the geology of the post-obduction period.

\section{Miocene Népoui Group}

Dated Miocene deposits on Grande Terre are restricted to the area of Népoui on the southwestern coast (Fig. 13). A seemingly "basal" (see below) siliciclastic conglomeratic formation and an overlying shallow-water carbonate formation have been identified by several studies (e.g. Coudray 1976, 1977a; Gubler \& Pomeyrol 1948; Paris 1981). More recently, detailed geological mapping, followed by boreholes, and offshore dredges, have led to a greatly-improved knowledge of this depositional system, notably through the new discovery of a Miocene carbonate unit underlying the previously identified basal conglomerate (Maurizot et al. 2016; Maurizot \& Rouillard 2015; Maurizot et al. 2015; Sevin 2014; Tournadour et al. submitted). Drill core from the Miocene series was obtained on Pindaï Peninsula and Grimault Island for the assessment of carbonate resources in the 1990s (Le Berre \& Maurizot 1992; Tessarolo 1997) and for scientific purposes (S2, $170 \mathrm{~m}$ and S4, $103 \mathrm{~m}$ ) in the 2010s (Maurizot et al. 2016; Maurizot et al. 2015).

The lowest Miocene beds of the Népoui Group (Népoui Group is not to be confused with Lower/Upper Népoui formations) unconformably overlie the Late Eocene turbidites of the Népoui-Koumac Group (cf. chapter 4, this memoir) and the Poya Terrane (cf. chapter 5, this memoir) as well as associated serpentinite slices. They do not overlie unconformably the Peridotite Nappe and its regolith cover which, however, does seem to have supplied most of the clastic fraction of the sedimentary rocks. Miocene strata dip gently $\left(<5^{\circ}\right)$ to the southwest and form various flat-topped peninsulas and islands around Népoui village. The group has been subdivided into two formations, and six members, the stratigraphic nomenclature of which is presented in Fig. 14 and 17.

\section{Lower Népoui Formation}

The Lower Népoui Formation outcrops are restricted to the western coast of the Pindaï Peninsula in the so-called Chapeau Chinois area where only the upper part of the formation crops out on a c. $20 \mathrm{~m}$ high coastal cliff. The basal part is not exposed but has been intersected by the S4 core drill at c. 104 $\mathrm{m}$ BSL. The base of the formation unconformably overlies the Late Eocene turbidites of the NépouiKoumac Group. The members in bottom to top order are described below.

The basal part of the Chapeau Chinois Limestone Member, consists of a $10 \mathrm{~cm}$ thick layer of reworked pebbles and fragments of Eocene turbidites intermixed with red algae bioclasts. The rest of the member is a c. $90 \mathrm{~m}$ thick succession of massive, coral-rich limestones, separated by irregular erosional surfaces. The carbonate components are large broken pieces of non-wave-resistant scleractinian, encrusting non-articulated coralline red algae, and large benthic foraminifers, mainly Miogypsina, Heterostegina, Neorotalia, and Amphistegina. Fine to medium-grained lithoclasts, dominantly peridotite, serpentinite, and chromite grains, their weathered equivalents, and related regolith components (thinly bedded lateritic mud, ferricrete grains, and supergene silica fragments) are common. The palaeoenvironment can be interpreted as a sea-grass meadow with scattered scleractininan bioconstructions, of high to moderate energy, at the transition between the meso- to 
euphotic zone, with brief influxes of laterite-derived material, deposited in proximal ramp environments (Maurizot et al. 2016).

The c. $24 \mathrm{~m}$ thick Operculina Green Sand Member comprises unconsolidated sandstone with green-tobrownish oxidized serpentinite grains, large flat benthic foraminifers such as Heterostegina and Operculina, and some planktonic foraminifera. The palaeoenvironment is deeper than the underlying member and oligotrophic.

The uppermost Xuudhen Limestone Member, c. $10 \mathrm{~m}$ thick, consists of rhodalgal-foraminiferal floatstones with common platy corals, rhodoliths, and characteristic large lepidocyclinids (dominantly Eulepidina ephippioides, up to $3 \mathrm{~cm}$ in diameter, Nephrolepidina and Cycloclypeus). The palaeoenvironment is of mesophotic zone, below fair-weather wave base.

In terms of overall depositional settings, the Lower Népoui Formation is interpreted as recording a proximal carbonate ramp rather than a rimmed platform (Maurizot et al. 2016).

\section{Upper Népoui Formation}

The $c .70 \mathrm{~m}$ thick Pindaï Conglomerate Member overlies unconformably the Lower Népoui Formation and the Eocene turbidites of the Népoui-Koumac Group. The unconformity between the conglomerates and the folded flysch is well exposed in the road cut of the mining track along the west coast of the Muéo peninsula (Fig. 15). The conglomerates are commonly channelized and dominantly made of clast- to sandy matrix-supported polylithologic conglomerates. Clasts comprise rounded gravel-, pebble- and cobble-sized fragments of dominant serpentinized peridotite, subordinate basalt of Poya Terrane, amphibolite, and leucogabbro derived from the Peridotite Nappe. Clasts of material from the weathering profile of the Peridotite Nappe (saprolite, laterite, ferricrete, supergene silica, and magnesite) are common; the finest grained deposits are nontronitic clays (Fe-Mg smectite), and alluvial laterite. Both the sandy/clayey matrix and the conglomerate clasts are pervasively weathered and impregnated with supergene ferruginous silica (opal, chalcedony, amorphous silica, and small submillimetric quartz), and in situ (untransported) magnesite concretions. To the south of Muéo Peninsula, the conglomerate is composed of highly weathered peridotite pebbles, with silicified rims and saprolitic cores, in a silcrete matrix. The pebble cores are commonly removed by erosion, leaving only the hard silcrete matrix. In contrast, basalt clasts from the Poya Terrane are fresh. The average orientation of cross bedding and imbricated pebbles indicates a general north to south transport direction across the whole member (Coudray 1976). Overall, Pindaï Conglomerate represents a fluviodeltaic wedge deposit. To the south of Muéo peninsula, a 1-2 m-thick ferricrete is intercalated in the conglomerate, displaying rhizocretions and ferruginous tree stumps in life position, diagnostic of subaerial exposure. Large silicified wood fragments are common in the conglomerate and include trunks up to $1 \mathrm{~m}$ in length, branches, twigs, fragments of bark, seeds, and leaves. Casuarinaceae seeds are well preserved and Arecaceae stems are common (Coudray 1976).

The Wharf Member, 10 to $20 \mathrm{~m}$ thick, is a transitional unit between the dominantly terrestrial siliciclastic deposits of the Pindaï Conglomerate and the overlying marine carbonate deposits (Fig. 16). It consists of siliciclastic conglomerate, sandstone, siltstone, and claystone interbedded with marine lithoclastic and foraminiferal limestones. The unit is characterized by the occurrence of various pedogenic surface features (rhizocretions, root traces, circum-granular cracks), surficial burrowing, silica and iron rich concretions, moldic porosity development, and local karstification. Fluvial conglomerate and sands, with similar clast compositions to the Pindaï Conglomerate, are channelized 
with trough cross bedding. Pebbles and grains are always coated with thin, $\mathrm{mm}$-thick rinds of radiating carbonate fibers, typical of cementation in a vadose environment. Limestones contain a marine macrofauna of gastropods, bivalves, regular and irregular sea urchins, sparse colonies of corals, and coralline red algae. The environment is supra to subtidal, in a generally low energy setting, with some higher energy facies. Plant remains are common. To the top of the member, a $10 \mathrm{~cm}$ thick clayey limestone horizon, likely a coastal storm deposit, contains well preserved leaves, some of them with drip tip imprints. The flora includes nearly 50 unique plant morphotypes: dicotyledonous angiosperm, ferns, a leafy conifer branch, and infructescences of Casuarinaceae (Fisher et al. 2015).

The Népü Limestone Member is up to $20 \mathrm{~m}$ thick and consists of metre-thick bioclastic packstone/grainstone to floatstone beds, interbedded with thin terrigenous layers (reworked lateritic mud, green to brown sandstones with serpentinite grains, and microconglomerates, Fig. 16). The bioclastic limestone beds are mainly composed of large non-wave-resistant scleractinian, nonarticulated coralline algae pieces, porcelaineous foraminifera (miliolids, alveolinids, thick rotaliids, and amphisteginids). The rich macrofauna includes bivalves (oysters, Spondylus, Lithophaga), gastropods (including Haliothidae), sea urchins, and arthropods fragments (crustacean claws). The environment is shallow marine, colonized by sparse scleractinian bioconstructions, within or at the vicinity of seagrass meadows, in the euphotic zone, on the inner part of a gently-dipping ramp or on top of an open platform.

\section{Age}

The age of the Népoui Group is based on both benthic and planktic foram biostratigraphy and strontium isotope dating of urchin spines (Fig. 17). The Lower Népoui Formation is Late ChattianAquitanian (oldest Sr age of c. $24 \mathrm{Ma}$ ), and the Upper Népoui Formation is Burdigalian (Maurizot et al. 2016). Strontium isotope ages allow precise bracketing of the Pindaï Conglomerate between 21 and $19 \mathrm{Ma}$. Several sites in the Népoui Group have been cored for palaeomagnetic work to obtain derived ages. Only one site, in a silicified horizon of the Pindaï Conglomerate, has so far given a valid result, the mean pole encompassing the 25-10 Ma poles of the APWP reference curve for Australia (Sevin 2014).

\section{Summary}

The transgression of the exposed base of the Népoui Group (24 Ma), and the development of the oldest regolith on the Peridotite Nappe (25 Ma) are of comparable age. Both Lower and Upper Népoui formations include carbonate ramps with extensive sea-grass meadows and scarce scleractinian colonies, developing in the euphotic zone.

Episodic reworking of regolith elements from the Peridotite Nappe in the lowermost deposit of the Chapeau Chinois Limestone Member, and abundant grains of serpentinite in the Green Sand Member suggests that both the top of the Peridotite Nappe and its basal sole were already exposed to weathering and erosion at this stage. An upsurge of erosion, with the same components, is recorded during the Aquitanian-Burdigalian transition, by the deposit of the thick and coarse Pindai Conglomerate. Dominant elements of the basal sole of the Peridotite Nappe, and subordinate elements of the underlying Poya Terrane, suggest that both nappes were well emergent and deeply dissected during the Burdigalian; a fact that is confirmed by the (1) absence of Miocene deposits directly overlying the Peridotite Nappe, and (2) presence of silcrete blocks, remnants of the silicified matrix of the Pindaï Conglomerate, scattered on the Poya Terrane, at the foot of the Peridotite Nappe, 
in the area between Voh and Poya (see below). In the Miocene, what are now isolated peridotite klippes of the West Coast were likely well delineated as larger individual massifs.

None of the global eustatic variations recorded during the Late Oligocene and Early Miocene has an amplitude greater than the sediment thickness of either the Lower Népoui Formation or the Upper Népoui Formation. Considering only eustasy, the $80 \mathrm{~m}$-thick Pindaï Conglomerate deposited in the 19$21 \mathrm{Ma}$ interval would suggest an equivalent sea-level fall, however, that period corresponds to a global sea level rise (De Boer et al. 2012). Consequently, only a vigorous uplift can explain the deposit of the conglomerate and, in a general manner, the development pattern of the Népoui Group appears to be largely driven by local tectonic uplift and subsidence.

\section{Other occurrences}

Between Voh and Poya, there are occurrences of large blocks of the very resistant silicified matrix of the characteristic Pindaï Conglomerate, studded with empty ghost pebbles. These attest to the former extent of that member (Chardon \& Chevillotte 2006a).

To the southwest of the Koniambo Massif, a small conglomerate outlier rests on the Poya Terrane at Tambounan Peak. Beneath the conglomerate base, the underlying basalts are weathered to kaoliniterich clay over a distance of $1 \mathrm{~m}$. The conglomerate is highly weathered. The conglomerate grades upwards into ferruginous cross-bedded sandstone made up of iron oxy-hydroxides minerals with a matrix of green nickeliferous hydrous-Mg silicate, reworked laterite, and clay (smectite). The top is capped by a siliceous ferricrete with rhizocretions. Although it strongly resembles the Pindaï Conglomerate, this outlier has been tentatively correlated with the Muéo Formation (Paris 1981 and see below) or with the lower sequence of the Gwa N'Doro Formation (Chardon \& Chevillotte 2006).

Offshore, Miocene rocks have been dredged on the western slope of Grande Terre, at depth of 500 to $1000 \mathrm{~m}$, during the IPOD (Investigating Post-Obduction Deposits) scientific cruise (Collot et al. 2013; Maurizot \& Rouillard 2015). Although many of the dredged rocks might have been reworked on the slope and not be in situ, they provide some indication of the former extent of Miocene deposits. Dredge DR5 is located at c. $70 \mathrm{~km}$ to the NW of the Népoui type locality. It recovered bioclastic limestone with benthic foraminifera including lepidocyclinids and one large Eulepidina, typical of the Lower Népoui Formation, intermixed with Pliocene planktonic foraminifera. Dredges DR11-12 are located immediately downslope of the main outcrops of the Népoui Group. The dredged samples comprise conglomerate with well-rounded pebbles of serpentinite, granitoids, amphibolite, dolerite, felsic gabbros, and rare grains of ferricrete. Pebbles are weathered, with silica and oxide rims displaying a centripetal progression. Pebbles and grains are coated with rinds of radiating fibres of carbonate. The conglomerate matrix is a micritic limestone with bioclasts of benthic and planktonic foraminifera, gastropod, corals, algae, echinids, and bryozoan. The benthic microfauna comprises Oligocene-Middle Miocene lepidocyclinids and rotalids. These rocks are similar to Pindaï Conglomerate and Wharf members.

\section{Muéo Formation}

The Muéo Formation was informally defined by Carroué \& Espirat (1967) and has been mentioned by several authors (Coudray 1969; Gonord \& Trescases 1970; Paris 1981). The formation actually corresponds to a regolith palaeo-surface, associated with karst features, and some terrestrial deposits, that is mainly present in the Népoui Peninsula, and over much more steeply-dipping Miocene deposits. Small outliers resting directly upon Poya Terrane basalts in the area of Montagne Rouges have been 
tentatively ascribed to Muéo Formation. On the Pindaï Peninsula, beneath the Muéo Formation, the Nepü Limestone Member is stained by red iron oxy-hydroxides, and is pervasively dolomitised and karstified. Karst cavities are partly filled with reworked laterite associated with rhizocretions, and silicified plant remains. Incomplete cavity infill has left open spaces in their upper parts. Other sedimentary accumulations are blocks of supergene silica, ferricrete, and goethite pisoliths or nodules, in a matrix of reworked red laterite. Most of these materials are derived from the erosion of ultramafic weathering profiles. Nontronitic black and green clays are also present. The formation remains undated, but must be post-Burdigalian, and testifies to an exposure of the Early Miocene depositional system.

\section{Gwa N'Doro Formation}

In the mountainous Kouaoua area (Fig. 17), several remnants of fluviatile deposits are collectively referred to as the Gwa N'Doro Formation (Avias 1952a; Bibent et al. 1972; Guy 1976; Guy et al. 1979; Maurizot \& Lafoy 2004a; Orloff 1968). They are preserved either on crests or slopes, between altitudes of 200 to $480 \mathrm{~m}$. The deposits are deeply dissected by erosion, locally faulted, partly weathered, and in places topped by ferricrete. The thickest occurrence does not exceed $200 \mathrm{~m}$ at Kasouri. The deposits exclusively rework the Peridotite Nappe and its weathering products.

Gwa N'Doro and Ouéna occurrences (Maurizot \& Lafoy 2004a) comprise very coarse conglomerate with rounded cobbles, imbricated well-rounded pebbles, sands, and lateritic muds. The clastic components and the matrix are composed of fresh peridotite, serpentinite, felsic gabbros, ferricrete, silica fragments, oxi-hydroxide granules, and laterite. At the Gwa N'Doro type locality, the lower sequence (Chardon \& Chevillotte 2006a; Orloff \& Gonord 1968) is composed of a fining-upward conglomerate topped by a palaeosol with plant remains, and an upper sequence of coarse conglomerate that reworks and truncates both the lower sequence and the weathered peridotite substrate. The sediments are in turn weathered, with replacement of the matrix by silica or $\mathrm{Mg}(\mathrm{Ni})$ bearing silicates. Weathering of the pebbles develops as concentric centripetal silicification. Faults crosscutting the conglomerate, show progressive lateral saprolitisation and lateritisation, and have clearly controlled water circulation and weathering. Thin veneers of garnierite in cracks are common. In some cases, a ferruginous weathering profile or ferricrete lies on top of the sequence. At the Gwa N'Doro locality, extensional faults, typically gravity-driven due to slope failure, crosscut the deposits with high- and shallow-angle normal faults, the latter being localised along bedding-parallel decollement between the two sequences. Back-rotation of blocks of the upper sequence is observed (Fig. 18c).

The deposits at both Gwa N'Doro and Ouéna are typical of a fluvial channel to floodplain environment. They are remarkably similar to that of the Miocene Pindaï Conglomerate. Although scattered in an area within a $5 \mathrm{~km}$ radius of Kouaoua village, these sedimentary relicts seemingly belong to the upstream part of an ancient (and likely single) fluvial aggradation system, having filled valleys and canyons in a mountainous landscape, somewhat similar to that of the present-day around Kouaoua.

There is no direct dating of the formation, and indirect dating by palaeomagnetism has proven unsuccessful (Quesnel et al. 2013b). On the basis of lithology, facies, and geomorphological relationships, the upper part of the Gwa N'Doro Formation has been correlated with the Upper Népoui Formation, notably with the Pindaï Conglomerate (Chardon \& Chevillotte 2006), and thus the lower 
part has been speculatively ascribed to the Oligocene. However, given all the uncertainties, a conservative age assignment of Miocene seems preferable.

\section{Fluvio-lacustrine Formation}

The Fluvio-lacustrine Formation (Fl-L Fm, Guillon \& Trescases 1976; Trescases 1975) refers to the sedimentary infill of intra-montane basins, located in the south of Massif du Sud (Fig. 19). It characteristically contains reworked laterite, ferricrete fragments, and other supergene materials, and results from the erosion of weathering profiles developed on the Peridotite Nappe. The bedding of the formation is generally horizontal, and its top is characterised by a flat surface, partially capped by ferricrete. This top horizon is well exposed at the tourist site of Madeleine Waterfall (Chute de la Madeleine, Plaine des Lacs; fig. 20a). The formation's extent corresponds partly to the present-day hydrographic network. The thickness of the infill is commonly in the range $40-60 \mathrm{~m}$ in the axial part of palaeo-valleys and reaches a maximum of 80 metres (Trescases 1975) in a borehole in the Rivière Blanche area. As far as can be determined from the international literature, the Fluvio-lacustrine Formation seemingly has no equivalent in other countries that have similar large weathered peridotite outcrops.

\section{Lithology}

Most of the information on the Fluvio-lacustrine Formation comes from sections in the upstream part of the Rivière des Pirogues where erosion has cut the infill over its full thickness (Fig. 20b), thus providing very good exposures (Quesnel et al. 2008; Folcher et al. 2013; Folcher et al. 2014; Folcher et al. 2015; Folcher 2016). In this area, the base of the formation is commonly composed of a conglomerate, a few metres thick. This basal horizon may rest directly on the peridotite bedrock or upon an in situ truncated weathering profile. The conglomerate comprises cobbles and boulders transported by mass flow, or more commonly pebbles corresponding to alluvial deposits. The clasts are mainly peridotite and ferricrete. The rest of the valley infill sections are dominated by coarse sands, silts and clayey nontronitic red-brown laterite-derived material. The dominant elements are fragments of iron oxide, mainly goethite, as nodules or pisoliths, subordinate chromite grains, supergene silica fragments, and quartz. Sands are locally rich in chromite forming beds of a few $\mathrm{cm}$ thick (cf. chapter 10, this memoir). The deposits are overall structureless and tabular, with few cross bedding and channel features. Clasts are mostly angular, and poorly-sorted. Clasts of clay, laminated silt, or iron oxide concretions indicate internal reworking. A few syn-sedimentary hydroplastic and conjugate normal compaction faults are observed. Dense horizons of entangled root and rootlet casts in living position, rich in iron oxide, are common (Fig. 20c). Ferruginous or carbonaceous tree stumps are not uncommon, as well as thin ferruginous layers rich in imprints of fossil leaves. Decimetre to metre thick whitish or pinkish layers, are composed of weathered felsic rock pebbles in a clayey matrix (kaolinite, gibbsite, halloysite), that most probably come from the erosion of weathering profiles developed on cumulate gabbros and felsic dykes. In the downstream part of the Rivière des Pirogues the base of the Fluvio-lacustrine Formation rests directly on cumulate gabbros. There it consists of several metres of pure white kaolinite. Thin peat horizons, associated with nontronitic clays, have also been recorded from the Rivière Blanche area (Guillon \& Trescases 1976). The bulk chemistry of the Fluvio-lacustrine Formation deposits resembles that of the surrounding ultramafic laterite. The iron content is generally over $45 \%$. Nickel is less than $1 \%$, whereas chromium is variable, from 1 to $10 \%$ (Folcher 2016, and chapter 10 , this memoir). 
Diagenetic precipitation of iron oxides in the Rivière des Pirogues area is ubiquitous and takes many forms. Iron oxides, mainly goethite, are concentrated in many discontinuities of the deposits, along bedding, in fractures, in zones of permeability contrast, and also form variously shaped contorted concretions. These secondary features can roughly mimic cross-stratification, and locally obscure primary bedding. Iron oxide stalactites can hang beneath horizontal septa in interbed voids. Some steeply-dipping cross-cutting septa are composed of two ferruginous narrow planes separated by a median thin void, the lower plane being draped by goethite concretion ripples. Such structures likely correspond likely to open cracks, fractures or faults where free flowing groundwater has deposited iron oxide on both sides. All these structures result from the precipitation of iron-oversaturated groundwater either in the water table or its fluctuation zone. The deposits, which are partly made of reworked weathering products, are in turn weathered. Peridotite and gabbro pebbles and boulders, display concentric weathering rinds and are transformed into saprolite. The topmost ferricrete horizon seals the infill (Fig. 20a).

In the other basins, the Fluvio-lacustrine Formation is less well-documented, and is known from borehole logs of varying quality; the holes were drilled to reach nickel deposits concealed below the low grade and non-economic Fl-L Fm cover. In the Lac de Yaté area, the Fl-L Fm deposits are in continuity with those of the upstream Pirogues River basin. The Lac de Yate is an artificial reservoir extending upstream from the Yaté Dam, in which the water depth does not exceed $25 \mathrm{~m}$. Before flooding, several circular-shaped lakes were present on top of the Fl-L Fm infill. The Fl-L Fm is also known In the Plaine des Lacs area. Here, the lobate shape of the basin, and the occurrence of several circular lakes on top of the infill, have been interpreted as a 'poljes', resulting from the coalescence of multiple sinkholes (Trescases 1975). Subsequent drilling has revealed palaeo-valleys, and a maximum thickness of $50 \mathrm{~m}$ of Fl-L Fm, that precludes such an interpretation. The Kwé Ouest basin infill is well constrained by recent boreholes (Folcher 2016). Despite a catchment smaller than the other basins, the FI-L Fm reaches a maximum thickness of $60 \mathrm{~m}$ and fills up a $\mathrm{V}$-shaped palaeo-valley. It rests entirely on in situ nickel-rich weathering profiles; however, it lacks a basal conglomerate and has a generally fine grain size. Such deep incision and infilling of a rather restricted and short watershed (the system extends over only $2 \mathrm{~km}$ in length) is surprising, as is the abrupt downstream termination of the deposit against an in situ weathering profile.

The overall lithological and sedimentological features of the Fluvio-lacustrine Formation points to a fluvial depositional system with dominant floodplain and subordinate channel sequences. Channel sequences are made up of cross-bedded coarse to medium sands, intermixed with intraclasts ripped up from upstream banks. Floodplain and lacustrine deposits are represented by clay and thinly laminated reworked laterite. Rhizocretion horizons correspond to vegetation settlement and pedogenesis on abandonment floodplain surfaces. On top of these sequences, reworked laterite mudstone horizons, indurated by iron-oxide, are rich in exceptionally preserved leaves and seeds (Fig. 20d; Locatelli 2013) and, rarely, insects in which very fine detail is preserved (Quesnel et al. 2015).

On the scale of the whole formation, the overall grainsize trend is one of fining upward. In most of the basins (e.g. Pirogues, Plaine des Lacs, Kwé Ouest) the clastic infill seems to have taken place without major interruptions. In particular, there is no interstratified ferricrete that would indicate a substantial pause in the filling, except for the topmost one. At a basin scale the fluvial system began with deep incision and high energy deposits. Once a local basin was filled up a thick ferricrete developed. Weathering has been ongoing, before and during sedimentation. 
An attempt to date the carbonaceous plant remains in kaolinite layers of the Pirogue River area by ${ }^{14} \mathrm{C}$ methods indicated contents below analytical detection limit, thus indicating an age greater than $30 \mathrm{ky}$ (Augé \& Maurizot 2002). Sixteen (U-Th)/He dates on goethite from three samples of rhizocretion cores and rinds range from 0.2 to $9.4 \mathrm{Ma}$, with most in the interval $0.8-2.7 \mathrm{Ma}$. In the zoned concretions (which always have progressive, never discontinuous, core-to-rind transitions) the age differences between cores and rinds is not consistent; thus, these results are considered doubtful (Bailly et al. 2014). Indirect dating by palaeomagnetic methods in the Pirogues River Basin (Fig. 12) has provided age estimates of 25-20 Ma in haematite from a ferruginous horizon rich in fossil leaves in the middle part of the formation, and 10-20 Ma in haematite and 0-5 Ma in goethite in ferruginous horizons close to the terminal ferricrete (Folcher 2016; Quesnel et al. 2008; Quesnel et al. 2015; Quesnel et al. 2013b). A maximum age of c. $25 \mathrm{Ma}$ is therefore suggested for the Fluvio-lacustrine Formation, and a minimum age of 0-5 Ma for the terminal ferricrete, which recorded the end of infill and weathering of the sediments.

\section{Summary}

The morphological analysis of the Massif du Sud provides clues on the origin of the Fluvio-lacustrine Formation (Folcher 2016; Folcher et al. 2014; Folcher et al. 2013; Folcher et al. 2015; Maurizot et al. 2004; Maurizot et al. 2002a; Maurizot et al. 2002b). The main basins that host the terrestrial deposits are all located at altitudes of 100-200 m. Some of them (to the north) are still active, i.e. correspond to the present-day hydrographic network: e.g. the Rivière Blanche, Rivière Bleue, Lac de Yaté, and Creek Pernod rivers, and flow on top of the Fl-L Fm infill whose surface is sub-horizontal. In the Plaine des Lacs and Lac de Yaté basins, the lakes can be interpreted as remnants of this fluvio-lacustrine system.

The Fluvio-lacustrine Formation system lies to the southwest of the uplifted Unia-Goro block (Fig. 19; 500 to $600 \mathrm{~m}$ ). This block, bounded to the southwest by en-echelon faults, offsets morphological features and weathering surfaces topped by ferricrete that are in the range of 0-25 Ma (Sevin et al. 2012a). The Fl-L Fm fluvial infill which crops out in the northern part of the Pirogues River, was obviously connected to the infill of the upstream part of the Yaté River. The backward regression and erosion of the Pirogue River, flowing to the south, has captured this upstream part of the former Yaté catchment initially flowing to the north. The Yaté and Kwé Binyi rivers, outlets of the Yate and Plaine des Lacs basins respectively, crosscut the Unia-Goro block through deep and narrow sinuous gorges before reaching the coastline (sea level). These features are typical of an uplift-driven antecedent drainage pattern (Ritter 2006). The Wadjana Waterfall, to the south of Goro, is an example of a hanging valley, where the stream has not yet cut through the Goro fault scarp. Along the north-eastern coast, the Unia-Goro block is bounded by a Late Pleistocene (125 ka) uplifted reef (Cabioch et al. 1996) that reaches an average altitude of $10 \mathrm{~m}$ near Yaté. The uplifted reef is itself indented by a marine notch formed during the last climatic optimum (4 to $5.5 \mathrm{ka}$ ), which is locally shifted to slightly higher elevations than elsewhere (see below, "The reef and lagoon system", this chapter).

These overall features indicate that the Unia-Goro block is a major element in the creation and development of the Fluvio-lacustrine Formation. It seems to have played the role of a dam whose uplift has triggered the upstream accumulation of the Fl-L Fm deposits. The uplift is associated with a general downward tilt to the SW of that southern part of New Caledonia, attested by regolith surfaces, lowering from NE to SW (Fig. 11), and capture of the upstream part of the former Yaté catchment by 
the Rivière des Pirogues. This positive movement of the block is still active during the Late Pleistocene and Holocene as indicated by the uplifted reef along the coastline of Yaté.

In summary, the Fl-L Fm was deposited within a primitive hydrographic network established as early as the Late Oligocene-Early Miocene, in the south of Grande Terre, following the post-obduction uplift that is identified in the Népoui area at this time (Sevin 2014). It could have been active or re-activated up to the present day.

\section{Other occurrences}

Other isolated, un-named and un-correlated occurrences of fluviatile to lacustrine deposits are common in the Massif du Sud. The most important ones are in the Dumbéa (Guillon \& Trescases 1976) and Tomo (Maurizot \& Lafoy 1999) river catchments. They occur as terraces within these valleys, and likely accumulated adjacent to intramontane mass wasting that formed landslide dams and barrier lakes. The weak weathering of peridotite boulders and pebbles in these fluviatile deposits suggests a recent age. Other sedimentary relicts unrelated to a fully organised hydrosystem are known in the Tontouta watershed (Chardon \& Chevillotte 2006; Vogt \& Podvin 1983), and Prony basin (Folcher 2016).

\section{Offshore domain}

\section{New Caledonia Trough and Loyalty Basin}

Following Late Eocene obduction (cf. chapter 5, this memoir), post-obduction isostasic rebound (Moretti \& Turcotte 1985; Lagabrielle et al. 2005; Chardon \& Chevillotte 2006; Chardon et al. 2008; Sevin et al. 2014; Collot et al. 2017) has led to the deposition of a c. $5 \mathrm{~km}$-thick sedimentary sequence in the adjacent New Caledonia Trough and Loyalty Basin (Fig. 21a and b).

According to modelling of geophysical data, the Loyalty Basin is underlain by oceanic crust that is the continuation of the ophiolite obducted over Grande Terre (Collot et al. 1987). A major unconformity is located on the western margin of the basin, i.e. on the northeast margin of Grande Terre, truncating an underlying unit interpreted as an erosional surface that has been consecutively flooded, therefore showing evidence for strong vertical motions (Bitoun \& Récy 1982). In several seismic profiles of this northeastern margin of Grande Terre, a clastic wedge, interpreted as Miocene, has been traced (Fig. 21d), topped by a prominent palaeosurface (Chardon et al. 2008). A second aggradational fluvio-deltaic wedge, possibly of Late Miocene to Early Pliocene age, covered in turn by an erosional lateritic palaeosurface, overlies this first system. Both units are overlain by a Late Pliocene to Quaternary transgressive carbonate ramp grading into the modern reef barrier.

The southwestern margin of Grande Terre exhibits superposed compressional structures, provisionally identified by Rigolot \& Pelletier (1988). At the foot of the southwestern margin of the middle part of Grande Terre between 2500 and $3500 \mathrm{~m}$ depth, an arcuate deep-sea terrace, extends over a distance of c. $200 \mathrm{~km}$ for a width of $50 \mathrm{~km}$, and forms a prominent morphological feature (Collot et al., 2017, and Fig. 21a and b). Seismic profiles revealed a $5 \mathrm{~km}$ thick sedimentary section forming a complex fan system comprising stacked folds, thrust faults, back thrusts, pop-up structures, duplexes, and piggyback basins. The deformation does not appear to have been triggered catastrophically, and conspicuous allochthonous blocks (e.g. of peridotite or basalt) are absent. The whole feature resembles a Deep Water Fold and Thrust Belt (DWFTB) model sensu Morley et al. (2011) and referred to as such in this chapter. This SW-verging fault system is deeply rooted along a concave upward basal 
décollement about $5 \mathrm{~km}$ beneath the seafloor (Fig. 21c). Sea floor deformation and seismic profiles indicate that the system had minor activity until recently. Detailed seismic analysis reveals that the basal décollement of the DWFTB is progressively warped upward toward the western margin of New Caledonia. The dip reaches as high as $10 \pm 2^{\circ}$ to the SW along the margin, revealing that the inner part of the structure rises toward the margin of New Caledonia (Collot et al., 2017).

The sediments of the lowermost unit involved in the structure onlap the regional Late Eocene seismic reflector, a continuous key horizon extending across New Caledonia Trough, and tilted towards New Caledonia's SW margin (Collot et al. 2008). The deformed sedimentary pile is undrilled. The only dating comes from piston cores acquired in the recent sediments lying in the axis of the New Caledonia Trough. They comprise alternating hemipelagic oozes and deepwater turbidites of mixed carbonate and siliciclastic composition. The base of the core is dated at $1.26 \mathrm{Ma}$ (Foan 2015). The front of the deformed structure is therefore interlayered into the Oligocene to Holocene sedimentary pile deposited above the Eocene reflector. A Miocene age has been proposed for most of the sediments, whose deformation would have started during Late Miocene (Collot et al., 2017).

Two interpretations have been proposed for this post obduction fold and thrust structure (see below "Discussion and tectonic models"). An active margin origin has been proposed, the structure being interpreted as an accretionary prism, deeply rooted along a palaeosubduction interface, plunging below Grande Terre (Cluzel et al. 2001). Conversely, a passive margin origin related to important differential vertical movements following the latest-Eocene obduction, and therefore a gravity-driven process has been proposed (Collot et al. 2017).

Conglomerates, with dominant basaltic pebbles, and subordinate ultramafic related clasts (serpentine, gabbros, pyroxenite) have been recovered by dredges in several sites to the SE of Ile des Pins, at depths between 400 and $2000 \mathrm{~m}$ (Fig. 21a and e). Biomicrites and biocalcarenites, recovered from flat top edges on the Pine and Félicité ridges, as well as the matrix of the conglomerates have been dated at Early to Late Miocene (Bitoun \& Récy 1982; Daniel et al. 1976). The conglomerate pebbles, as well as in situ basalts are either correlated with Poya Terrane basalt or interpreted as Late Oligocene intraplate volcanism (Mortimer et al. 2014). Some of the bioclastic limestones are typical of fore-reef environments implying an important post-depositional subsidence. Seismic lines south of lle des Pins reveal thick sediments deposited in prominent graben or half graben and controlled by extensional tectonics, displaying fan-shaped syn-deformation to post-deformation deposits and spectacular normal faulting of the inferred extent of the Peridotite Nappe (Patriat et al. 2017). Although normal faults are only small and seen at outcrop scale onshore, large normal faults have been proposed to exist offshore (Chardon et al. 2008; Chardon \& Chevillotte 2006; Lagabrielle \& Chauvet 2008; Lagabrielle et al. 2013; Lagabrielle et al. 2005). The flat top (some of them tilted) observed on some ridges (Fig. 21e) are interpreted as wave-cut palaeo-erosion surfaces, blanketed by reef to lagoon deposits of possible Miocene age. On the Pine Ridge which is interpreted as the southeastern continuation of the Peridotite Nappe, a former weathering surface similar to what is observed in the south of Massif du Sud (cf. above, Regolith development, this chapter) has been proposed (Patriat et al. 2017).

In summary, offshore information from around the margin of Grande-Terre point to the presence of Miocene conglomerate and shallow limestone, partly equivalent to those of the Miocene Népoui Group, originally deposited in a shallow environment, and therefore subsided to much deeper context. 


\section{Lord Howe Rise, and Fairway and Norfolk ridges}

In contrast to the onshore geology of New Caledonia, where the Oligocene-Miocene sedimentary record is fragmentary, marine sedimentary rocks of this age are seemingly widespread elsewhere across northern Zealandia (Fig. 22) and reflect regional subsidence. Significant hiatuses and facies changes between Eocene and Miocene strata, are recognized in DSDP 206, 207, and 208 boreholes on the Lord Howe Rise and in the New Caledonia Trough. On the Lord Howe Rise, widespread deposition of a continuous unit of biogenic sediments of constant thickness resting above the regional EoceneOligocene unconformity is observed (Bache et al. 2014; Collot et al. 2008; Sutherland et al. 2010). At DSDP sites 208 and 588 (Burns et al. 1973; Kennett et al. 1986) $594 \mathrm{~m}$ and $488 \mathrm{~m}$ respectively of Neogene foraminiferal nannofossil ooze and chalk were recovered; seismic profiles reveal a very uniform seismic unit with sub-parallel and low amplitude reflections. However, in the basins, subtle differences in thickness in the Neogene succession are observed on seismic data and could be explained by additional sediment input generated by deepwater gravity processes (Pattier et al. 2015; Rouillard et al. 2017).

Submerged shallow marine isolated Neogene carbonate platforms can be inferred from seismic data, swath bathymetry and dredging of the Norfolk and Fairway Ridges, and also in the Loyalty Basin, yet very few data have been published on this topic (Daniel et al. 1976). Shallow water foraminiferal Miocene limestone has been dredged from the Lansdowne Bank and Nereus Reef (Richer de Forges et al. 1986, 1987). The underlying substrate includes hydrothermally altered Late Cretaceous intraplate lavas (Mortimer et al. 2018). In DSDP 587, subordinate coarse-grained bioclastic sediments were recovered in the relatively homogeneous Neogene pelagic ooze, and were interpreted as turbidite deposits originating from the isolated carbonate platforms of the Lansdowne Bank area, possibly during sea level lowstands (Kennett et al. 1986).

Widespread intraplate volcanism characterizes the Oligocene to Neogene period across Zealandia (Mortimer et al. 2018). This includes the Oligo-Miocene hotspot trails of the Tasmantid and Lord Howe chains (Exon et al. 2006; McDougall \& Duncan 1988; Quilty 1993) as well as more diffuse edifices such as the Capel-Faust seamounts (Exon et al. 2004; Van de Beuque et al. 1998) on the Lord Howe Rise, the Lansdowne Bank area (Mortimer et al. 2018; Seton et al. 2016; Williams et al. 2016) and the numerous seamounts located on the eastern and western Norfolk Ridge (Rigolot 1988). It is noteworthy that evidence for this volcanism is also seen in DSDP wells in the form of ash layers or clays potentially derived from the alteration of volcanic material.

\section{Quaternary deposits}

\section{Onshore domain}

The southwestern coast of Grande Terre preserves a range of Pleistocene coastal and terrestrial landforms and formations which are absent on the northeastern coast.

\section{Aeolianites}

Aeolianites (wind-blown, weakly lithified coastal sand dunes) have been identified in several coastal areas of New Caledonia (Fig. 23), notably outside Baie de Saint Vincent (southwestern coast), the eastern part of lle des Pins, and Ouvéa lagoon (Loyalty Islands). Outside Baie de Saint Vincent, the deposits form an alignment of $40 \mathrm{~km}$ (Fig. 23 c, Fig. 24a) facing the western lagoon (Avias 1965; Avias \& Coudray 1965; Bird \& Iltis 1985; Coudray 1976). In this area the aeolianite deposits reach an altitude of $110 \mathrm{~m}$ on lle Hugon and extend down to an unknown depth below sea level (on many coastal wave- 
cut platforms (Fig. 24b) they are covered by modern corals). The well-named Ilots Champignon (Mushroom Islets) are a low elevated dome of aeolianites, emergent from the lagoon, and with a carved marine notch around their whole periphery (Fig. 24c).

The aeolianites are mainly composed of angular calcareous well-sorted sand-sized bioclasts (algae, foraminifers, echinids, molluscs, corals, bryozoans). Subordinate terrigenous lithoclasts include rounded fluviatile grains of quartz, feldspar, serpentinite, orthopyroxene, chromite. Serpentine and chromite grains form commonly thin millimetre-thick horizons, often with an erosive base suggesting concentration of heavy minerals by brief rainfall during runoff episodes. The cement of these weakly indurated aeolianites is commonly composed of sparry calcite. The source of the sand comes likely from the mouths of rivers whose catchments include large portions of ultramafic massifs providing the terrigenous lithoclasts, and from coastal beaches providing the bioclasts.

Cross-stratification with dip $>30^{\circ}$, grain size distribution, and lack of bioturbation, are typical of windblown processes (Coudray 1976). The majority of the leeward steeply-dipping foresets are generally preserved whereas the windward gently dipping topsets with truncations and erosional surfaces are rare. According to Coudray (1976) all sedimentary structures, as well as the accretion and migration of the stacked dune bodies, indicate a dominant wind from the SE, similar in direction to present day trade winds. Occasionally, aeolianite beds are fractured and normal offset of a few centimetres on microfaults are often visible.

Pointe Guillois (Fig. 24d), at the southern tip of Ile Hugon, faces the dominant wind and is blanketed by thick aeolianite deposits, up to an altitude of $110 \mathrm{~m}$. The exposed section shows several sets of dunes, separated by hiatuses in sedimentation marked by red horizons (montmorillonite, goethite), corresponding to weathering episodes. The uppermost sequence is crosscut and overprinted by numerous rhizocretions, and capped by a continuous calcrete horizon in which large thick-shelled terrestrial gastropods of the genus Placostylus, are fossilized. At the base of the calcrete, the dune deposits are brecciated and weakly indurated. This topmost calcrete extends on the windward slopes of the many islands and peninsula of the Baie de Saint Vincent, usually resting directly on the basement rocks. This complex succession suggests that there were several episodes of aeolianite deposition.

The Pliocene to Present Day gastropod Placostylus mariei has been dated (Baltzer \& Dugas 1977; Coudray 1976) by ${ }^{14} \mathrm{C}$ methods at $6.5 \pm 0.1,18 \pm 0.2,22 \pm 8$, and $>30 \mathrm{ka}$ BP, i.e. Late Pleistocene to Holocene. The lagoon surrounding Grande Terre became emergent several times during episodes of low sea-level stand during Quaternary glacial events. The evidence for this is palaeo-valleys carved in the bottom of the lagoon and connected to the passes of the barrier reef (Cabioch et al. 1999; Cabioch et al. 1996; Coudray 1977a; Coudray 1977b; Flamand 2006; Frank et al. 2006; Le Roy et al. 2008). This palaeo-hydrosystem, which displays many numerous meanders and ox-bows is submerged at present (Fig. 23c). The aeolianites of Baie de Saint Vincent form a NW-SE alignment, and palaeo-river path in the lagoon displays a conspicuous change in direction, from transverse to longitudinal, when crossing this alignment. Altogether, these features attest to the presence of an almost continuous ancient shallow water bar, established during a low sea level period. Both the lagoonal sand and the alluvium of the palaeo-mouth of the Ouenghi and Tontouta rivers, whose estuaries were located downstream from their present day locations, were exposed to palaeo-trade winds, providing particles for dune accumulation. 
At lle des Pins (Fig. 23b), a $6 \mathrm{~km}$ long ridge of aeolianites, oriented NNE-SSW, is exposed on the eastern coast of the island. The ridge is slightly asymmetric with a steep slope facing east and a gentle one facing west. The ridge is probably oriented normal to the inferred palaeo-wind direction similar to that displayed by aeolianites of the Baie de Saint Vincent, and to the present day trade winds. The rock is exclusively composed of bioclasts. The ridge culminates at an altitude of $77 \mathrm{~m}$, and rests on the uplifted fringing reef plateau, which stands at an altitude of c. $20 \mathrm{~m}$. Corals from the reef have been dated from 120 to $>200$ ka BP (Guillon et al. 1986). There is no evidence to determine whether the aeolianites were deposited before, during, or after the uplift of the fringing reef.

In Ouvéa (Loyalty Islands) the small Udetch islet (cf. chapter 6, this memoir) is off-axis from the Pleïade du Nord girdle of islets, and is made of aeolianites (Maurizot \& Lafoy 2004b). It displays almost vertical eroded cliffs which rest on the floor of the Ouvéa lagoon.

\section{Calcrete}

Surficial calcretes (also termed caliche) are very common on the southwestern coast of Grande Terre. They are preferentially found on peninsulas and islands e.g. Nouméa, Népoui, Koumac peninsulas, Bourail coastal area, Baie de Saint Vincent, and Népoui islands. Carbonate substrates such as the Eocene Flysch, Miocene carbonate Népoui Group, and aeolianites seems to favour their development, but is not a necessary condition since calcrete may also locally rest on volcaniclastic or volcanic rocks.

Calcrete generally form a soft white crust, 1 to 3 metres thick, lying on the convex shapes of the present day topography, and masking the underlying fresh rocks. Affected by present day erosion, they generally delineate a prominent fringe on top of most cliffs. At the base of a calcrete profile, carbonate material fills thin laminar cracks parallel to the surface, the density of which increases upward. A spherulitic texture may occur in the massive overlying calcrete. Rhizocretions are a typical feature, and terrestrial gastropods of the genus Placostylus are common.

A pedogenic origin is therefore universally agreed. Calcrete formation is usually taken as marking periods of relative aridity (Wright 2008). Worldwide, calcretes are commonly associated with calcic vertisol (Alonso-Zarza \& Wright 2010).

\section{Gypsum-bearing vertisol}

In New Caledonia gypsum is known only on the southwestern coast. It has been sporadically mined in the past (cf. chapter 9, this memoir). It was originally interpreted as a marine evaporite (Piroutet 1917; Avias \& Drot 1952; Routhier 1953) but is now recognized of pedogenic origin (Podwojewski 1995). Some gypsum occurs in marshland areas, e.g. in the tidal zone of Mara, near Baie de Téremba (Avias 1952b; Baltzer 1965). However, the majority of gypsum occurrences are located inland (up to $10 \mathrm{~km}$ ), at altitudes of up to $160 \mathrm{~m}$ (e.g. top of Leprédour Island).

Gypsum is always associated with Ca- and Mg-smectite-rich vertisol soils, 1 to $10 \mathrm{~m}$ in thickness, resulting from the weathering of different sulphide bearing units, mainly basalts of the Poya Terrane, volcaniclastic deposits (Eocene Flysch, greywackes of the basement), or alluvium (Beaudou et al. 1983; Latham et al. 1978; Tercinier 1963). Gypsum occurs as disseminated centimetre-size, petal-shaped crystals or as large sand roses, and may constitute more than $50 \%$ of the volume of the host soil (Le Berre 1990, 1991). Carbonate (calcite, aragonite, magnesite) concretions are also present in the deposits. Detailed studies have placed these occurrences in their pedogenic and geomorphological 
context (Podwojewski 1988, 1992, 1993, 1994, 1995). Vertisols usually form in a tropical climate with contrasting seasons, with alternating dry and wet periods (Podwojewski 1995).

The sulphur isotopic ratio ${ }^{34} \mathrm{~S} /{ }^{32} \mathrm{~S}$ has been used as a tracer to identify the origin of the gypsum (Podwojewski 1994, 1995). By this method it has been determined that ${ }^{34} \mathrm{~S} /{ }^{32} \mathrm{~S}$ was partially related to the nature of the bedrock and that there was a linear inverse correlation between ${ }^{34} \mathrm{~S} /{ }^{32} \mathrm{~S}$ gypsum and the distance from the coast. Near the shore, isotopic ratios are typical of sea water suggesting that a major fraction of sulphur is likely brought by sea spume penetrating the vertisols through cracks. The ratios decrease inland at the expense of a minor continental source whose signature does correspond to the disseminated sulphur of the bedrock.

Various Ca-Mg nodules in the vertisols have been dated by ${ }^{14} \mathrm{C}$ methods (Iltis 1989; Latham 1986a; Podwojewski 1992). The main cluster of ages is between 15000 and $28000 \mathrm{yr} \mathrm{BP}$, which suggests that much gypsum was formed during the last glaciation.

\section{Landslides in the Peridotite Nappe}

In the mountainous Peridotite Nappe, a number of large mass-wasting deposits (Fig. 25) have been identified. From upstream to downstream, typical morphology includes concave head scarp, hummocky surface, and bulging convex toe. Depending on the nature and proportion of rocky peridotite vs unconsolidated laterite, a wide variety of features may be formed. These include rockfalls, rockslides (rotational or translational), landslides, debris flows, mud flows, and combinations of them. Mass-wasting deposits may remain perched upslope (Fig. 25b 2), or spread away far from their source downslope (Fig. 25b 5); in the drainage network they can form landslide dams and barrier lakes. Some of these deposits are more than $5 \mathrm{~km}$ wide and have moved material downslope through a vertical height of $0.5 \mathrm{~km}$ (Maurizot et al. 2007; Rouet 2009). There is no equivalent of these outside the Peridotite Nappe. About 200 mass-wasting features have been identified in the Massif du Sud, and a number of other occurrences are known in the west coast klippes. Some of them are likely very old and have been mined for nickel (e.g. Vulcain nickel mine, cf. chapter 10, this memoir), whereas other are still active and a threat to the infrastructure and population (e.g. Mont Dore). Mass-wasting deposits arise from the natural process of gravity driven dismantling of the ultramafic massifs in the high montane areas of the Peridotite Nappe, dense fracturing of the bedrock, deep weathering under the tropical climate, and steep slopes. Fracturing and weathering are two mutually-reinforcing feedback processes that ultimately lead to the thorough conversion of the initial peridotite into laterite.

Heavy rainfall episodes are triggering factors for mass wasting. In the Massif du Sud, mass wasting is dominantly occurring on slopes oriented toward the south and subordinately toward the east and west. This distribution may be either controlled by an external forcing factor like climate (exposure to dominant rain or wind), or favoured by an internal structure such as fracture network (steeper fracture planes in this directions).

\section{Unconsolidated sediment in lakes and caves}

The sedimentary infill of several sinkholes in peridotite has been cored (Hope 2015; Hope \& Pask 1998; Stevenson et al. 2001; Stevenson et al. 2010; Stevenson \& Hope 2005). Carbon-14 dating shows that organic muds accumulated in some of them prior to 40000 BP. Generally, the topmost sediment layers cored in lakes encompass the 3500 last years BP (Cabioch et al. 2008b; Hope \& Pask 1998; Wirrmann et al. 2006; Wirrmann et al. 2011; Wirmann et al. 2007). The sediment records indicate alternating 
drier and wetter stages, probably correlating with the EI Niño-Southern Oscillation (Corrège et al. 2000; Corrège et al. 2004; Corrège et al. 2001; Wirrmann et al. 2011). Details of Quaternary fossil sites and contents are given in chapter 8 "Palaeobiogeography" of this memoir. Recent global events such as the Medieval Warm Period (1000-1400 AD) and the Little Ice Age (1400-1900 AD) are recorded in corals and lake sediments (Corrège et al. 2004; Corrège et al. 2001; Wirrmann et al. 2011).

\section{River alluvium}

Not much attention has been paid to the mapping of Grand Terre's alluvial deposits. Rivers of the southwestern coast and of northeastern coast have contrasting morphologies related to a general southwest-ward tilt of Grande Terre (cf. below, "Neotectonic" section). On the southwestern coast, valleys are longer, and have shallower gradients and stepped alluvial terraces; active channels are generally entrenched in extensive floodplains. The systems end in large deltas in the lagoon, and are fringed by mangrove flats associated with salt marshes. In contrast, on the northeastern coast, valleys are shorter, steeper, and lack terraces; they are generally terminate in deep estuaries with restricted mangrove areas (Bonvallot 2012). The longest river in Grand Terre is the Diahot River. This is in the north of the island with a watershed of c. $590 \mathrm{~km}^{2}$ and length of $55 \mathrm{~km}$, compared to an average length of $30 \mathrm{~km}$ for the rest of the island's rivers. It is the only river of Grande Terre to have a mean NW-SE direction. Older terraces of the south western coast and along the Diahot River are more weathered and bear a weathering profile. As such they display a distinctive red colors, having a higher goethite and clay content.

\section{Summary}

High-altitude fluvial terraces, aeolianites, calcrete, and gypsum-bearing vertisols of the southwestern coast of Grande Terre are geomorphologically associated with, and are dissected by the present day erosion. Calcretes occur on convex hills and gypsum bearing vertisols in concave valleys. Vertisols on modern hillslopes extend downhill onto and across older alluvial terraces. The topmost aeolianite deposits are capped conformably by calcrete. These deposits are likely contemporaneous with the last deglaciation episode.

\section{Offshore domain}

\section{The reef and lagoon system}

The barrier reef and lagoon system that surrounds Grande Terre forms the second largest reef complex in the world after the Australian Great Barrier Reef (Cabioch et al. 1996; Chevalier 1973; Le Roy et al. 2008). The barrier is c. $1400 \mathrm{~km}$ in circumference. A lagoon and reef system forms a continuous strip of c. $60 \mathrm{~km}$ in average width and c. $600 \mathrm{~km}$ in length, between Le Grand Passage in the north and Ile des Pins in the south (Fig. 26a). The depth of the lagoon varies between 0 and c. $60 \mathrm{~m}$, and the distance between the coast line and the barrier reef varies from 0 (e.g. at Bourail) to c. $30 \mathrm{~km}$. The coast line itself is bordered by a complex and discontinuous fringing reef. The barrier is a typical example of rimmed shelf sensu Emery (1996), bounded by very steep, outer slopes. Living reef communities are sensitive gauges of environmental change, including eustatic and climate change processes and, as such, have generated an extensive scientific literature.

Core drills, dredges, swath bathymetry and seismic reflection surveys of the reefs and lagoon are available. In the 1980s, about 40 shallow boreholes were cored on the fringing reef of Grande Terre (Cabioch 1988; Cabioch et al. 1999; Cabioch et al. 1995; Cabioch et al. 1996; Cabioch et al. 1989; Degaugue-Michalski 1993; Fontes et al. 1977; Lecolle \& Cabioch 1988). Deeper boreholes have been 
cored-drilled on the reef barrier and on islets close to it, notably at îlot Tenia ( $257 \mathrm{~m}$, Avias \& Coudray 1967; Coudray 1976; Coudray \& Cussey 1973), îlot Amédée (127 m, Cabioch et al. 1993; Lecolle 1991; Payri \& Cabioch 2004), and Îlot Kendec (149 m depth). Modern sedimentation in the lagoon has been the topic of several research programs (Chevillon 1989; Chevillon 1996a; Chevillon 1996b; Chevillon 2005, 2012; Chevillon \& Clavier 1988; Chevillon et al. 1992; Fernandez et al. 2006; Guilcher 1965; Launay 1970, 1971, 1972; Launay \& Récy 1972; Maurizot \& Bouysse 1989; Pelletier et al. 2006; Richer de Forges et al. 1997) and of systematic mapping in the southwestern and eastern lagoon (Dugas et al. 1982; Dugas et al. 1980a; Dugas et al. 1978; Dugas et al. 1981). Shallow seismic reflection and swath bathymetry data (Bégot et al. 2004; Chevillotte et al. 2004, 2005; Dugas et al. 1980b; Lafoy et al. 2000; Lagabrielle et al. 2005; Le Roy et al. 2008; Thinon 2015) has been acquired mainly in the southwestern and eastern lagoon.

From the Grande Terre coastline to the barrier reef, several zones are distinguished in the lagoon (Andréfouët \& Torres-Pullizza 2004; Chardy et al. 1988; Chevillon 2005, 2012). Close to the land, red coloured clay and ooze are deposited in front of the mouth of the main rivers, sourced from the iron rich soils and laterite of Grande Terre. Fringing reefs and mangroves occupy the coastal area between these outlets. In the lagoon, the terrigenous deposits grade into mixed bioclastic sands and anoxic iron sulphide-bearing ooze; isolated sponge, and/or algal reef constructions are present. Internal patch reefs, sand cays, and islets with permanent vegetation build up in the lagoon and are constructed from reef framework and bioclastic sand. They are commonly aligned on ridges parallel to the Grande Terre coastline and can develop their own micro-lagoon and reef systems (Guilcher 1988; Thomassin \& Vasseur 1981; Yamano et al. 2014). Islets are transient, rapidly evolving, environmentally sensitive features and some of them are subject to possible disappearance in the future at multi-decadal scale (Garcin et al. 2016, Vendé-Leclerc et al. 2016, and http://carto.oblic.georep.nc). Most of them probably formed during the last Holocene highstand (Yamano et al. 2014) before the $2800 \mathrm{yr}$ BP sea level fall. The back-barrier reef zone is composed of pure, well-sorted bioclastic sand commonly forming submarine sand dunes, punctuated by reef pinacles at water depths of 5 to $20 \mathrm{~m}$. Wellindurated and compacted limestone horizons are commonly present and in places crop out at the bottom of the lagoon. These hard slabs were probably cemented when the lagoon was emergent during glacial lowstand periods. The functional barrier reef, interrupted by reef passes, marks the external limit of the system.

Downstream from the main Grande Terre rivers and upstream from the reef passes, the bottom of the lagoon is carved by submarine channels, interpreted as submerged former fluvial valleys which once connected the terrestrial to the open oceanic domains when the lagoon bottom was emergent (e.g. Fig. 23 c and Fig. 28 c,d,e) during Pleistocene sea level lowstands (Avias 1959; Debenay 1987; Dugas 1974; Dugas et al. 1980b; Le Roy et al. 2008). In the southwestern lagoon, the channels form a complex polyphase network with meanders and abandoned channels. Capture, superimposition, and channel migration are commonly observed. Integrated seismic and stratigraphic surveys suggests that the oldest deposits in the southwestern lagoon can be correlated with the sea level highstand at $210 \mathrm{ka}$ and thus, that lagoon infill corresponds to only two glacial-interglacial cycles (Chevillotte et al. 2005; Lagabrielle et al. 2005). A similar layout is found on the northeastern lagoon (Chardon et al. 2008). Each cycle is characterized by a phase of incision of the river system in the limestone substrate of the lagoon and barrier reef during sea level lowering, followed by a partial filling phase of the valleys during sea level rise. 
In the southwestern lagoon, the straight borders of some canyons (Fig. 28) as well as asymmetrical infill on seismic sections, has led to the suggestion that they are fault controlled graben (Lafoy et al. 2000; Lagabrielle et al. 2005). However, there is no evidence of typical syn-rift graben infill or of normal faulting within the sediments (Le Roy et al. 2008). The observed sedimentary structures probably result from sediment compaction, so the interpretation that canyons are structurally controlled by an underlying fractured basement remains open. In both the southwestern and northeastern lagoons the older channels are oblique or parallel to the barrier reef and coastline, whilst the younger ones are perpendicular (Chardon et al. 2008; Le Roy et al. 2008). In the southwestern lagoon, migration of the channels to the southeast is observed. These evolutions in the different parts of the lagoon might be explained by an increasing seaward subsidence of the reef barrier - lagoon system through time (see below).

The fringing and barrier reefs are generally made up of a Holocene to Present day unit and a $125 \mathrm{ka}$ Late Pleistocene unit. Older Pleistocene reefs are present only in the barrier reef (Cabioch et al. 1999; Cabioch et al. 1996; Chevillotte et al. 2005). The 125 ka reef is present almost everywhere including $\mathrm{d}^{\prime}$ Entrecasteaux Reef. The earliest Holocene reef does not exceed $8.5 \mathrm{ka}$ in age suggesting that sea surface temperatures were too cold for reef growing before that age. In the south of Grande Terre the fringing reef established earlier (5 ka BP) than in the north (4.2 ka BP, Cabioch et al. 1995). The elevation of the intra-reef Holocene-Pleistocene boundary varies (Fig. 26). The Holocene reef is constituted by a sequence of catch-up growth mode of organisms sensu Neumann \& Macintyre (1985). Most commonly the Holocene unit vertically overlies the $125 \mathrm{ka}$ unit. In that case a thin calcrete caps the 125 ka reef reflecting dry climatic conditions when the Pleistocene reef was emergent. In the southwest of Grande Terre, the Holocene - Late Pleistocene unconformity is mostly generally submerged at - $6 \mathrm{~m}$. On M'ba islet, the Holocene-Pleistocene boundary is at -2.3 to $-5 \mathrm{~m}$ below mean sea level (Castellaro 1999; Yamano et al. 2014). On the barrier reef that boundary is often deeper.

There are some exceptions to the above general rule. In Bourail area (Ilot Vert) the Holocene and Pleistocene units are juxtaposed forming step-like reef terraces (Degaugue-Michalski 1993; Lecolle \& Cabioch 1988). In the Yate and lle des Pins areas, the 125 ka reef is uplifted, reaching an average altitude of 10 and $20 \mathrm{~m}$ respectively. To the north of Yaté, in the Unia area, the 125 ka reef has been cross cut by drilling at $-7 \mathrm{~m}$ under the present day functional reef (Cabioch 1988). Seaward of Yaté, the present day functional reef is drowned to c. 15-20 m under mean sea level and broken into several segments. In the Hienghène area a double notch system extends over $3 \mathrm{~km}$; here, strata with Middle Holocene fossil corals (Cabioch et al. 1996; Launay \& Récy 1972), occur as high as altitudes of 13 m, and plunge to the north and the south (Fig. 26b), whilst the Holocene fringing reef rest directly over the rocky substratum at an altitude of $-7 \mathrm{~m}$.

The southwestern main barrier reef is commonly formed of one single linear ridge interrupted by passes. The north-eastern barrier reef is commonly subdivided into double or triple ridges, the more seaward segments being drowned to $15-20$ m below mean sea level. In detail, the barrier reef is a complex edifice, 100 to $200 \mathrm{~m}$ in vertical thickness, made up of several superposed units. Most constructional corals grow only in the upper part of the photic zone (euphotic zone at depth less than $20 \mathrm{~m}$ ), so this thickness cannot be explained without subsidence of the substrate. The barrier reef consists of a stack of detrital or framework units separated by unconformities, marked by erosion, diagenesis, dissolution features, and occurrences of palaeosols. 
The fore-reef and margins of Grande Terre have been surveyed by several scientific cruises including swath bathymetry and dredges (Pelletier et al. 2012), as deep as - $1000 \mathrm{~m}$. The surveys revealed the presence of Quaternary terraces on the fore reef slope, between 10 and $200 \mathrm{~m}$ water depth. These terraces have been correlated with the top of palaeo-reef units developed during the last sea level highstands (Flamand 2006). The most extensive terrace, located between 70 and $85 \mathrm{~m}$ water depth, is widespread along New Caledonia margins.

A reconstruction of the barrier reef formation based on integration of biofacies correlation, discontinuities, nannofossil and pollen biostratigraphy, magnetostratigraphy, U-series dating, and isotopic ratios of oxygen and carbon from the boreholes on Amédée, Ténia and Kendec islets has been proposed (Cabioch et al. 1999; Cabioch et al. 2008a; Castellaro 1999; Frank et al. 2006; Payri \& Cabioch 2004). Eleven units are distinguished, constituting coral communities (in catch-up growth mode), built up or deposited during successive highstands in interglacial periods, separated by unconformities or hiatuses corresponding to emergence during sea level lowstands in glacial periods (Fig. 27). On Ténia Islet, nannofossil biostratigraphy indicates that the carbonate system with shallow water coral communities (mainly massive poritid forms) probably initiated at around 1.4 Ma (Early Pleistocene). The lowest units, in Amédée and Kendec boreholes, correspond to a carbonate ramp deposited in a non-rimmed shelf margin, and an open shallow-water environment. Typical framework reef tracts did not occur prior to $0.4 \mathrm{Ma}$ (Marine Isotope Stage 11, MIS-11; $408 \mathrm{ka}$ ) when climatic conditions became optimal (Cabioch et al. 2008a; Montaggioni et al. 2011) and the Late Quaternary 100 ky cyclicity was well established (Milankovitch 1920). The most extensive terrace, on the outer reef slope, between 70 and $85 \mathrm{~m}$ water depth, is correlated to the same MIS-11, and represent the onset of the barrier reef. Variation of depth of these terraces indicate that the barrier reef is segmented and composed by tilted blocks. The mean subsidence rates calculated from the depth of the terraces as well as from the barrier reef mean thickness, range from 0.08 to $0.20 \mathrm{~mm} / \mathrm{yr}$ on the southwestern margin (Flamand et al. 2008; Flamand 2006; Montaggioni et al. 2011).

Subsidence is increasing northward, southward, and seaward from Grand Terre as attested by the presence of the large northern and southern lagoons (Grand Lagon Nord, and Lagon Sud). A neutral point seems to exist in the Bourail area on the south-western coast where the Holocene and Late Pleistocene reefs are at the same altitude, and where the lagoon and barrier reef disappears locally. Some noteworthy exceptions occur on the eastern and south-eastern coast where localized uplift is observed although associated with stronger subsidence seaward. In the area of Yaté and lles des Pins the uplift is explain by the influence of the forebulge propagating in front of the east-dipping subduction zone of the Vanuatu active convergence zone (Fig. 26; Dubois et al. 1974; Dubois et al. 1977, chapter 6, this memoir, and references therein). The Holocene-Late Pleistocene reef relationship at Hienghène, which is out of the theoretical maximum $250 \mathrm{~km}$ influence of the Vanuatu forebulge (Lliboutry 1969), is more difficult to interpret.

\section{The oceanic domain}

The deep water sedimentary dynamics of New Caledonia's surrounding basins (New Caledonia Trough to the southwest, and Loyalty Basin to the northeast) remains poorly constrained. A few available gravity cores hint at the nature and variability of the sedimentary fluxes contributing to the basin infills (Pannetier 1990; Cotillon et al. 1992; Foan 2015). Such superficial cores reveal that four main types of sediments are being deposited into the deep basins. These are derived from (1) in-situ carbonate 
production in the water column (2) volcanic edifices, (3) erosion of terrestrial land (4) the reworking of carbonate sediments produced on shallow water platforms including reefs.

Although recovered mud, silts and sands are mainly calcareous (55-95\%), terrigeneous turbidites (5 to $40 \%$ ) rich in terrestrial debris (vegetation and ferricrete) and clays (illite, chlorite, smectite) have also been recovered in gravity cores in both basins (Cotillon et al. 1992). These cores reveal an increase in carbonate and mixed terrigeneous-carbonate turbidite frequency during sea-level highstands, correlated with an increase of biogenic carbonate production. The 36 m-thick MD06-3019 core, drilled at c. $100 \mathrm{~km}$ off the present day barrier reef in the New Caledonia Trough, comprises turbidites showing an increase in shallow water bioclasts and coral debris since MIS-11 (Foan 2015) which is interpreted to be related to the formation of the modern barrier reef. A study of sediments deposited offshore from Thio and Lifou in the Loyalty Basin also revealed that depositional areas are characterized by a high content in total carbonate and aragonite during sea level highstands. Conversely, lowstand periods are characterised by increasing terrigeneous fluxes derived from Grande Terre.

\section{Discussion and tectonic models}

A summary of available age data relevant to the post-obduction deposits and evolution is presented in Fig. 29. Climate (including sea-level change) and tectonics are the two main controlling factors. Global climate, from the Oligocene to Present, follows a long-term trend toward warmer temperatures (De Boer et al. 2012). In parallel with this change, New Caledonia moved continuously northward towards lower latitudes, as a result of global absolute plate motion (Seton et al. 2012, 2016). In New Caledonia, the emerging tropical climate is recorded by (1) corals that appear in the Miocene and are flourishing at present, and (2) regolith formation, especially on peridotites, that develops from the same period and is still presently forming. Both unweathered and weathered ultramafic formations produced a strong mineralogical and geochemical signal which can be recognized at a regional scale in the Neogene basins surrounding Grande Terre. Local and regional deformation events that followed the obduction of the Peridotite Nappe, are also important controls on the evolution and stability of the New Caledonia environment. With this framework, attempts may be made to identify some important episodes in the Neogene development of New Caledonia. Some relevant points include:

1- The timing of Peridotite Nappe obduction is well-constrained. The youngest sedimentary rocks, still marine, that are overthrust by the Peridotite Nappe are dated at $34 \mathrm{Ma}$ (chapter 5 , this memoir). The absence of dated Oligocene sedimentary deposits in onshore New Caledonia is notable. The oldest onland post-obduction deposits (reworking peridotite and regolith) are dated at c. $24 \mathrm{Ma}$ (base of Népoui Group), and c. $25 \mathrm{Ma}$ (less precise palaeomagnetic ages on regolith). To the south, near Nouméa, the Peridotite Nappe, its basal thrust and substrate, are crosscut by the Saint-Louis granodiorite intrusion dated at c. $27 \mathrm{Ma}$. In the adjacent New Caledonia Trough and South Loyalty Basin, continuous Late Eocene to Present deposition is well imaged by seismic surveys. However, only shallow boreholes have been drilled, allowing only the recent horizons to be dated. There is thus no information on the timing of obduction from the basins. Therefore, with current available data, there is an interval of c. $7 \mathrm{My}$ between latest pre-obduction (34 Ma) and earliest post-obduction (27 Ma) records, in which structural or stratigraphic age information is lacking.

2- Since obduction, the Peridotite Nappe has been in high and dominating structural and topographic positions, and therefore among the first units to be exposed. Its extreme mineralogy, and high sensitivity to erosion and weathering, make the Peridotite Nappe a major contributor to the siliciclastic component of all post-obduction sedimentary deposits (e.g. Népoui Group, Fluvio-lacustrine Formation). 
3- Magnesite concretions of meteoritic origin, observed locally in the basal serpentinite sole of the Peridotite Nappe, imply a subaerial environment for their emplacement. The majority of them are post-obduction. A minority have a syn-tectonic character and were more likely formed during limited post-obduction reactivations which are not time-constrained.

4- Shallow-level Late Oligocene granitoid plutons are confined close to the basal serpentinite sole of the Peridotite Nappe and the associated hydrothermal fluids have locally pervasively penetrated the peridotite/autochthon interface. The measured radiometric ages of crystallization (U-Pb on zircon), cooling (zircon and apatite fission track), and weathering (K-Ar and $\mathrm{Ar}-\mathrm{Ar}$ on $\mathrm{Mn}$ oxides) all overlap. Therefore, their uplift was probably fast and weathering early, less than $10 \mathrm{My}$ after intrusion.

5- The oldest regolith planation surfaces in New Caledonia are palaeomagnetically (and imprecisely) dated at c. $25 \mathrm{Ma}$. The latest Oligocene was thus a time of extensive weathering and landforming that may be tentatively correlated with the Late Oligocene Warm Event (LOWE; Zachos et al. 2001). Weathering is still active at present and this is likely why the magnetic residual signal is so commonly reset.

6- The Late Oligocene-Early Miocene (24-16 Ma) Népoui Group deposits do not directly overlie the Peridotite Nappe or its regolith which, however, did supply most of the clastic fraction of the sediments. So, by the Early Miocene, Grande Terre was already established as a deeply dissected mountainous area, dominated by ultramafic massifs, at the foot of which were lying the sediments of the Népoui Group.

7- The present double upwarp morphology displayed by the basal thrust of the Peridotite Nappe and the main regolith palaeo-surfaces on top of it is likely an inheritance of a long evolution that involves both obduction and post-obduction events.

8- Conspicuous large normal faults of inferred Oligocene - Neogene age are visible offshore on seismic lines. These faults define half-graben structures and control sedimentary infill (Fig. 21 and 30d). On Grande Terre such normal faults are obscure and controversial (Patriat et al. 2017). At the outcrop scale, many microtectonic indicators show extension or transcurrent senses of movement. Extrapolation of these to regional-scale structures might be misleading. For example, for many years, the so-called West Caledonian Fault Zone (WCFZ) was supposed to mark the boundary between allochthons and autochthon along the southwestern flank of Grande Terre (Black 1993; Brothers \& Black 1973; Lillie \& Brothers 1970; Paris 1981; Routhier 1953). The WCFZ was resurrected by some authors in the 2000s (Lagabrielle \& Chauvet 2008) as a major Neogene discontinuity. However, it most likely corresponds to the fortuitous alignment of genetically unrelated linear features coming from a polyphase tectonic history involving pre- and syn-obduction events.

An Oligocene-Holocene tectonic model, based on these points, is presented and discussed below (Fig. 30).

\section{Oligocene}

Two alternative models are proposed for the Oligocene granitoids. They could have been generated by

- a subduction zone with a slab dipping northeast under Grande Terre, or

- passive margin intraplate magmatism such as is seen elsewhere in Zealandia.

Part of the debate arise from the interpretation of the geochemical and isotopic characteristics of the granitoids. 
The negative HFSE geochemical anomalies of the granitoids are interpreted as resulting from a short lived NE-dipping Oligocene subduction of the New Caledonia Trough along the southwest coast of Grande Terre (Cluzel et al. 2001; Cluzel et al. 2005; Cluzel et al. 2012; Paquette \& Cluzel 2006). Such a new and failed subduction would result from the continuing plate convergence after the Late Eocene obduction and jump of the subduction to the southwest margin of Grande Terre over the oceanic or thinned continental crust of the New Caledonia Trough (Klingelhoefer et al. 2007). Additionally, weak but significant differences in trace element contents (mainly of $\mathrm{Nb}$ and HREE uncorrelated to differentiation) and ages of Saint Louis (27 Ma) and Koum (24 Ma) granitoids, are interpreted as resulting from the mineralogical and isotopic heterogeneity of the mantle below New Caledonia (Cluzel et al. 2005; Paquette \& Cluzel 2006, references therein). In detail, the subduction blocking would have started in the northeast of Grande Terre, at the end of the Eocene (Fig. 30a, and cf. chapter 5, this memoir), and led to the tensional break-off of the cold and brittle part of the Eocene subducted slab. The rupture may have propagated southeastward and reached southern New Caledonia in the Late Oligocene. Subduction of a new slab on the southwestern margin of Grande Terre with the same geometry as the old slab would be responsible for the Saint Louis granitoid emplacement (Fig. 30b left). Subsequent break-off of the old slab would have led to asthenospheric upwelling and the slightly different composition of the Koum granitoid, which lies closer to the northeast coast (Fig. 30c left).

An alternative intraplate (passive continental margin) setting for the Oligocene granitoids and coeval potassic lavas southeast of Grand Terre has been proposed (Fig. 30 bc right) by Mortimer et al. (2014). In this view, the Oligocene granitoids are considered to simply be part of a suite of low volume, subalkaline lavas and plutons that are widespread across the interior and around the margins of Zealandia (Mortimer et al. 2017).

These different views arise because the geochemistry of modern lavas derived from subcontinental mantle and erupting through continental crust may be difficult or impossible to distinguish from subduction-related magmas (e.g. Till et al. 2009). As such, without other supporting evidence of a subduction margin, the subduction model cannot be convincingly proven based solely on geochemical data.

One such piece of evidence might be the SW-verging fold and thrust system (the DWFTB of Collot et al 2017) affecting the sediments along the southwest margin of Grande Terre. However, this also has multiple and different interpretations. It has been interpreted as an accretionary wedge associated with a Late Eocene to Present NE dipping major overthrust or subduction plane (Rigolot \& Pelletier 1988, Rigolot 1989, Régnier et al. 1999; Sevin et al. 2014) i.e. supporting the interpretaton that the Oligocene granitoids are subduction-related. The alternative, passive margin, interpretation is that it represents gravity-driven collapse of the slope during Miocene uplift (Collot et al. 2017).

There are some other arguments in favor of an active, subduction margin setting:

- The metallogenic features of the Oligocene granitoids typically associated with subduction (cf. chapter 9, this memoir).

- The lateral variation of upper mantle structure beneath New Caledonia (Regnier et al., 1988).

- The negative gravity anomaly $\left(-50 \mathrm{mGal}\right.$ ) along the $\mathrm{SW}$ coast from $23^{\circ} \mathrm{S}$ to $18^{\circ} \mathrm{S}$ (Collot et al. 1988; Van De Beuque 1999). 
- The regional Late Eocene seismic reflector (Collot et al. 2008) as well as the Moho (Klingelhoefer et al. 2007) across New Caledonia Trough, both tilted NEward beneath Grande Terre SW margin.

Satisfactory resolution of these competing models remains to be done. The issue could potentially be solved by seismic tomography revealing the geometry of the deep crust and mantle structure of Grande Terre which has only been outlined in reconnaissance (Regnier 1988).

\section{Neogene}

The overall scarcity of Neogene sediments on Grande Terre, their dominant terrestrial nature, and the abundance of reworked elements coming from the Peridotite Nappe and its regolith, point to a continuum of uplift and emergence of the island during this period (Fig. $30 \mathrm{de}$ ). The onshore and offshore development pattern of the Neogene deposits seems to be largely driven by tectonic uplift pulses. Evidence includes the:

- $\quad$ presence of the Early Miocene Pindaï Conglomerate in the Népoui Group between 19 and 21 $\mathrm{Ma}$, which is not correlated with a climate-related event.

- deposition of the Muéo terrestrial Formation on top of the Népoui Group (post Early Miocene).

Conversely, offshore, sustained Neogene subsidence is attested by the:

- $\quad$ presence of Miocene shallow bioclastic limestones now at deeper water depths.

- collapsed Miocene sediments (DWFTB) offshore from the south western margin of Grande Terre whose deformation was active during Late Miocene and continued until recently.

Different models have tried to explain the prevailing processes controlling Neogene evolution. They fall into two categories. These are not mutually incompatible but emphasise processes operating at different scales:

- local development from a continuum of obduction (syn- to post-obduction including exhumation).

- regional Zealandia-wide development independent of obduction.

A post-orogenic extension model has been proposed (Lagabrielle \& Chauvet 2008; Lagabrielle et al. 2013; Lagabrielle et al. 2005) coming from Alpine models of continental collision. In this decompression or gravitational collapse model, a combination of large detachments and high-angle faults cut through the autochthon and allochthon, and result in overall thinning of the obducted ultramafic sheet. Another post-obduction extension model, in which vertical differential movements are the main driving mechanisms, has been proposed (Chardon \& Chevillotte 2006b; Collot et al. 2017; Lagabrielle et al. 2005; Moretti \& Turcotte 1985; Patriat et al. 2017). In this model, uplift and subsidence are controlled by isostatic rebound after thrusting and loading of the Norfolk Ridge by the dense material of the Peridotite Nappe. This would have triggered gravity-driven collapse of the DWFTB on the southwestern margin.

For some authors, extensional tectonics during the Oligocene - Neogene period in New Caledonia is simply a local expression of regional scale tectonic interactions between the Australian and Pacific plates in the SW Pacific-Zealandia region (Mortimer et al. 2014). Across Northern Zealandia, 
widespread Oligocene to Neogene subsidence is interpreted as the result of either relaxation following Eocene contraction and/or Neogene extensional opening of the South Fiji backarc basin. Eocene subsidence of New Caledonia Trough and transient uplift of the Lord Howe Rise are interpreted by Sutherland et al. (2010) as the result of the initiation of Tonga-Kermadec subduction. What is local to New Caledonia, rather than all of North Zealandia is the Late Miocene northeast-dipping subduction of the Australian Plate under the Vanuatu arc. This seems to be responsible for a shift from Early Neogene extension to a later transtensional regime, as suggested by microtectonic analysis (Chardon \& Chevillotte 2006b).

\section{Quaternary}

Grande Terre lacks a post-Early Miocene marine sedimentary record. On the Loyalty Ridge, atoll-stage reef barriers became established during the Pliocene (c. 5.3 Ma, cf. chapter 6, this memoir). Around Grande Terre, coral communities appeared at c. 1.4 Ma, and a reef barrier was established only at c. $400 \mathrm{Ka}$. This age difference for the onset of barrier reefs in the two area is surprising, because climate and latitude are similar for both Loyalty and Norfolk ridges. This may be due to different tectonic regimes during this period, the Loyalty Ridge being under the control of the westward propagation of the Vanuatu subduction forebulge (cf. chapter 6, this memoir), and Grande Terre being under the control of a post-obduction Neogene steady uplift and subsidence of its margin.

A general southwest-ward tilt of Grande Terre (Chardon \& Chevillotte 2006a; Cluzel et al. 2012; Davis 1925b) is observed at an island-wide scale, attested to by short and steep rivers on the northeast coast and longer and more-gently sloping valleys on the southwest coast. The occurrence of Miocene deposits on the southwest coast at low altitude $(<100 \mathrm{~m}$ and BSL), and on the northeast coast at altitudes of c. $500 \mathrm{~m}$, has been interpreted in the same way (Fig. 28). The influence of the forebulge which propagates in front of the northeast dipping Vanuatu subduction zone, active since $12 \mathrm{Ma}$, can locally explain some recent block faulting and uplift of the Pleistocene reef in the south of Grande Terre (Yaté), and Ile des Pins (see "Fluvio-Lacustrine Formation", and chapter 6, this memoir). It may also account for the Havanah fault zone (Lagabrielle et al. 2005), a group of NE-SW trending morphological lineaments that mark the southeast end of Grande Terre along which some evidence of recent tectonic movements is observed: 1) Wadjana hanging valley (Fig. 27a); 2) fault in the Holocene deposits of the lagoon (Fig. 27g); 3) a swarm of minor earthquakes (Fig. 27a). In this model, Havanah fault zone would be a low strain transfer- or scissor-structure, striking sub-perpendicular to the forebulge axis.

However, forebulge-tilting cannot account for the general double warp (see above Fig. 9) observed in the rest of the island, which is outside the forebulge influence, whose strike is not parallel to the forebulge axis, and whose amplitude is far greater than would be expected for such a deformation. The lagoon and barrier reef system surrounding Grande Terre, with the shallow southwest lagoon and the deeper northeast lagoon, present the opposite asymmetry to the onshore geology and drainage. The overall development of the Holocene and Late Pleistocene reef complex around Grande Terre points to a general tendency for its margins to subside, independent of eustatic fluctuations. This is in accordance with Darwin's classic theory of propagation of reef tracts from fringing to barrier positions around subsiding volcanoes (Darwin 1842), even though New Caledonia is continental. Such a seawardincreasing subsidence of the margin of Grande Terre fits with a continuum of low strain, extensional tectonics from the Neogene to Present. 
Altogether, these observations reveal a complex, superimposed, long-wavelength, low-strain Neogene-Quaternary tectonic evolution, probably arising from multiple causes. The deformation and seismic activity attests to limited but ongoing tectonic activity on Grande Terre.

\section{Acknowledgements}

This work is the result of formal and informal long-term collaboration between geologists from New Caledonia, New Zealand, and Australia. Funding was provided through several programmes, mainly the geological mapping programme of the Geological Survey of New Caledonia. The author and coauthors dedicate this paper to the memory of Guy Cabioch. Guy was a carbonate geologist and palaeoclimatologist. He spent many years studying the evolution of the reef complex in New Caledonia and the Pacific, bravely, in spite of his illness. He passed away on October 27, 2011. In this chapter, we have tried as best as possible to transcribe his knowledge on coral community evolution. We all miss him greatly and are honoured to have worked with him. The "Regolith development" section of this chapter benefited from several programmes of the funding agency CNRT "Centre National de Recherche et Technologie Nickel et son Environnement" (National Center for Research and Technology Nickel and its Environment, https://www.cnrt.nc). This chapter was improved by reviews from Dominic Strogen and Nick Mortimer. 


\section{Illustrations}

Fig. 1 Simplified geological map of New Caledonia emphasising the distribution of Oligocene-Recent rocks.

Fig. 2 Geological maps of post-obduction granitoid intrusions in the Peridotite Nappe. a) General map of the Massif du Sud. b) Koum pluton. c) Saint Louis pluton showing the crosscuting relationship of the granodiorite with the cover and the Peridotite Nappe.

Fig. 3 a) View from the west of Grand Koum granitoid; b) Weathered Grand Koum granitoid; c) Aerial view from the east of Petit Koum granitoid.

Fig. 4 Reverse concordia diagrams showing U-Pb ages of zircons analyzed from two granitoid dykes of Saint Louis suite, which crosscut autochthonous basement rocks; see location on Fig. 1.

Fig. 5 a) Total alkali-silica diagram after Le Bas et al. (1986) adapted by Wilson (1989) to show the classification of Saint Louis and Koum-Borindi granitoids in the fields of granodiorite and sub alkali granite; b) Expanded rare-earth and trace element spider diagram for Oligocene granitoids (data from Cluzel et al, 2005; primitive mantle normalization after Sun and McDonough, 1989); c) and d) $\mathrm{Nb}$ vs. $\mathrm{Y}$ and $\mathrm{Rb}$ vs. $\mathrm{Nb}+\mathrm{Y}$ discriminant diagrams of Pearce et al. (1984), to show the location of Oligocene granitoids in the field of volcanic-arc granites and a slightly higher $\mathrm{Nb}$ content in KoumBorindi rocks (green squares), which makes them closer to within-plate granites; e) Plot of ( $\mathrm{Nb} / \mathrm{La}$ ) $\mathrm{n}$ vs. $\mathrm{SiO}_{2}$ indicating a restricted correlation of decreasing $\mathrm{Nb}$ negative anomaly and differentiation, except for the more silica-rich granitoids $\left(\mathrm{SiO}_{2}>72 \%\right)$; f) $\left({ }^{87} \mathrm{Sr} /{ }^{86} \mathrm{Sr}\right)_{i}$ vs. $\varepsilon N d$ plot of Saint Louis and Koum-Borindi granitoids corrected for in situ decay at $27 \mathrm{Ma}$ and $24 \mathrm{Ma}$ respectively. (DMM: Depleted MORB Mantle; CHUR: Chondritic Uniform reservoir after (Zindler \& Hart 1986); g) Variation of ( $\mathrm{Nb} / \mathrm{La}) \mathrm{n}$ ( $\mathrm{Nb}$ negative anomaly) vs. $\varepsilon \mathrm{Nd}$ to suggest evidence for source mixing ( $\mathrm{Nb}$ and $\mathrm{La}$ normalized to the Primitive Mantle values as on Figure 5c ). h) Hf-Th-Ta diagram after Wood (1980) modified by Vermeesch (2006) to show the narrow field of compositions of Saint Louis volcanic-arc granitoids; and in contrast, the mixing line delineated by compositions of Koum-Borindi granitoids, which indicate some influence of an intraplate component. Oligocene lavas dredged on the Norfolk Ridge (Mortimer et al. 2014) are plotted for comparison.

Fig. 6 Some features of weathering profiles developed on ultramafic protolith. a) Common (and less used) terms used for the different levels of the weathering profile. b) Structure and thickness of the weathering profile. c) Smoothed variations of major and minor elements (compiled after Bailly et al. 2014; Latham 1986; Sevin 2014; Trescases 1975; Fritsch et al., 2014; Scott \& Pain 2009; Taylor \& Eggleton 2001). d) Typical proportion of mineral phases in a composite weathering profile (modified after Trescases 1973). e) Hydraulic conductivity values after Jeanpert 2016 and Join 2005).

Fig. 7 Sketches of deformation in saprolites: a) Folded and faulted iron nodules and sedimentary dyke in saprolite (Nakety); b) Ptygmatic folds and faults of an iron nodule sedimentary dyke in saprolite (Poro); c) downwarped weathered gabbro dykes in a saprolite matrix, draped over a bedrock core (Bogota); d) saprolite recumbent draped over bedrock cores (Goro mine, mining face, 2011). 
Fig. 8 Schematic representation of part of a weathering cell with a sinkhole to the left and a residual ridge to the right. Note the lateral thinning-out of the ferricrete towards the ridge. Dashed blue lines indicate the average water table level.

Fig. 9 a) Map of stepped weathering surfaces in the northeastern part of Massif du Sud. b) Schematic EW cross section. Modified from Chevillotte et al. 2006. Same color codes on a) and b).

Fig. 10 Simplified geological map and cross sections showing the twin longitudinal and transverse upwarping of Grande Terre (modified from Sevin et al. 2012).

Fig. 11 a) Simplified geological map of the southern part of Massif du Sud. b) Detail of the Port Boisé weathering cell. This basin is crosscut by a set of steep faults that uplifted its NE part. To the SW a gradual contact with the surrounding peridotite crest is preserved. To the NE, the same contact is incised by rivers, in response to uplift. c) Cross section showing the general lowering of the stepped ferricrete surfaces from north to south. Low altitude basins of the south are inverted to plateaux in the north. Note that the Port Boisé ferricrete surface plunges under sea level. 1,2,3, and 4) Examples of four stages of landforming (drawn at the same scale) from bedrock through basin and inverted plateau, to dissected mountains.

Fig. 12 Palaeomagnetic sample sites and results (after Sevin 2014). Numbers in boxes are interpreted ages of the magnetic vectors at each site.

Fig. 13 a) Geological map of the SW coast between Népoui and Kaala-Gomen showing Miocene rock occurrences. b) Topographic profiles (no vertical exaggeration) showing main regolith surfaces on Peridotite Nappe (thick black lines) and Miocene formations (orange).

Fig. 14 a) Geological map of the Népoui area. b) Cross section from Kopéto to Pindaï Peninsula.

Fig. 15 a) The unconformity of the Pindaï Conglomerate over the Eocene Népoui Flysch (road cut on the east coast of the Muéo Peninsula. b) Line drawing interpretation showing lower conglomerate with trough cross bedding and imbricated pebbles (labelled 1), fining upward into sandstone, overlain by more planar-bedded conglomerate (labelled 2 ).

Fig. 16 Upper Népoui Formation outcrops on Pindaï Peninsula. a) Aerial view from the east of the old Pindaï wharf locality. b) Close-up view from the sea of the reference section near the wharf.

Fig. 17 The Miocene Népoui Group: a) Correlated stratigraphic sections. b) Schematic model of stratigraphic architecture in the Late Burdigalian (modified after Maurizot et al 2016).

Fig. 18 Gwa N'Doro Formation. a) Simplified geological map of Kouaoua area. b) Sketch of the relative projected positions of the different outcrop localities, viewed from the SE (modified from Chardon et al. 2006). c) Cross section of Gwa N'Doro Formation at the type locality (modified after Chardon et al. 2006). d) Line drawing on an image of the lower member.

Fig. 19 a) Sketch map of the Fluvio-lacustrine Formation and some geomorphological features of the southeastern part of the Massif du Sud. The Yaté Lake reservoir has been removed to show the former sedimentary infill and the ancient topography. Brown and blue arrows indicate the direction of the ancient and present river flows respectively. b) Typical stratigraphic log of the deposits in the Rivière des Pirogues area (after Folcher 2016). 
Fig. 20 Typical outcrops and rocks from the Fluvio-lacustrine formation. a) Chutes de la Madeleine (Madeleine Waterfall): a typical outcrop of the topmost ferricrete on top of the Fl- $\mathrm{Fm}$ in the Plaine des Lacs; location on fig. 18. b) Road cut near Rivière des Pirogues. A layer of whitish clay (emphasised with white dashes) is visible half-way up the exposure. c) Ferrigenous rhizoconcretions. d) Fossil leaf imprints.

Fig. 21 Map of, and interpretations of seismic profiles through, the marine areas around Grande Terre (note different vertical and horizontal scales of sections. All profiles from the public Tasman Frontier Database (Sutherland et al. 2012). a) Map with main onshore outcrops and offshore dredges of Miocene rocks. b) Seismic profile across the northeastern extent of Grande Terre (line WNC117, modified after Lafoy et al. 1998). c) Seismic profile across the southwestern margin of Grande Terre showing the Deep Water Fold and Thrust Belt-like structure (line z1102, modified after Collot et al. 2017). d) Seismic profile across the north-eastern margin of Grande Terre (line NEOMARGES, modified after Chardon et al. 2008). 1) Miocene lower clastic wedge. 2) Miocene-Pliocene upper clastic unit covered by a lateritic palaeosurface. 3) Pliocene-Quaternary carbonate ramp (stars are indicating sub-unit progradation) grading westward into the Present Day rimmed carbonate platform. e) Seismic profile across the South Loyalty Basin, showing the development of Neogene and/or Quaternary carbonate platforms on top of structural ridges (offshore continuation of the New Caledonia ophiolite) and prominent normal faults (line s206-04, modified after Patriat et al. 2017).

Fig. 22 a) Bathymetric map of Northern Zealandia (seismic lines from Tasman Frontier DataBase, Sutherland et al. 2012). b) Seismic profile 206-01 across the northern Lord Howe Rise, showing the overall continuous, thick and low amplitude seismic character of the Oligocene-Neogene succession together with an intraplate volcanic edifice. The Oligocene-Neogene rests on the regional EoceneOligocene unconformity and on the acoustic basement of the Lord Howe Rise. c) Diagram summarizing the DSDP well data (modified from Collot 2009) showing the prominent hiatus between the Eocene and Oligo-Neogene.

Fig. 23 Aeolianite occurrences in New Caledonia. b) on lle des Pins. c) around Baie de Saint Vincent; d) Sketch of aeolianite section at Pointe Guillois: 1) Lower dune (steep leeward beds); 2) Lower red horizon; 3) Upper dune (steep leeward beds then gently dipping winward beds); 4) Rhizocretion developed over 1, 2, and 3; 5) Upper red horizon; 6); Terminal calcrete; 7) Topographic surface capped by calcrete. Black arrow indicates direction of palaeo-wind projected onto the section.

Fig. 24 Photo of aeolianite occurrences in Baie de Saint Vincent. a) Aerial view of the alignment of islands made of aeolianite corresponding to an ancient sand bar SW of Baie de Saint Vincent. b) Wave cut outcrop at Recif du Milieu. c) Ilot Champignon. d) Outcrop on lle Hugon.

Fig. 25 a) Map of landslides in the mountainous area of the Massif du Sud (after Rouet (2009) and Maurizot et al. (2007). b) Schematic model of evolution (from top to base) of mass wasting at the front of the Massif du Sud. Circled numbers on the map refer to evolution stages on the sketch.

Fig. 26 a) The reef-rimmed shelf around Grande Terre after Andréfouët et al. (2009), Andréfouët \& Torres-Pullizza (2004) and www.ifrecor.nc. Labels indicate localities, Holocene age, and Late Pleistocene (125 ka) altitude, of reef (after Cabioch 2003). b) Aerial oblique view of the south western barrier reef; view from the NW of Boulari Pass and Amédée Islet. c) View from the lagoon of 
Palaeocene limestone lying along the coastline to the south of Hienghène showing the Present Day notch at sea level, and an older notch at 4-5 m above, dipping to the NW (red dashed line).

Fig. 27 Schematic log of the Amédée core (after Cabioch et al. 1999, Payri et al. 2004, Cabioch et al. 2008, Flamant 2006, Montaggioni et al. 2011) showing correlations with the relative sea level curve (Waelbroeck et al. 2002), Marine Isotopic Stages (MISs), and terrace depth on the fore-reef slope.

Fig. 28 Southern lagoon, barrier reef, and continental slope. a) Map with palaeo-rivers, recent and active faults, and seismicity. Seismicity after Régnier et al. (1999). Note the Havanah (normal) fault zone marking the southern end of Grande Terre. b) Detail of the south-western barrier reef showing a prominent scarp hanging over a deep canyon head prone to mass wasting. c) to e) Details of the south western lagoon showing flooded palaeo-rivers. f) Seismic line of Calgon survey (modified from Le Roy et al. 2008) showing a fault in the Holocene deposits of the lagoon. Note the alignment of earthquake epicentres delineating an active fault in the lagoon within the Havanah fault zone. g) Sketch cross section (no scale) showing the asymmetry of Grande Terre. 1) Orange arrow: Inland asymmetry of the Neogene formations, particularly Miocene deposits. 2) White arrow: Offshore asymmetry between the southwest and northeast lagoons. The southwestern lagoon is shallower, islets are wider, and the barrier reef is a large single tract where passes are narrow. The northeastern lagoon is deeper, the barrier reef is a double or triple tract, drowned, and passes are large. The southwestern fore-reef and continental slopes are generally steeper, with a high density of linear and concave submarine drainage profiles and conspicuous submarine landslide morphology.

Fig. 29 Summary of post-obduction geological data including ages, regional geodynamic and climatic events. Global sea level curves according to De Boer et al. (2012). Mean palaeo-latitudes of New Caledonia, estimated by maps generated by GPlates (portal.gplates.org), and based on a hotspot reference frame, as in chapter 2 and 8 , this memoir.

Fig. 30 Sketch reconstruction of the north eastern part of Zealandia from Oligocene to Present. 


\section{References}

Acevedo-Gonzales, M. 1967. Clasificacion general y descripcion del carso cubano. Instituto National de Recursos Hidraulicos. Depto de Ingeniera Geologico. Publicacion Especial. La Habana, 4, 33-64.

Acevedo, M.J. \& Gutierrez, R. 1976. Nuevos reportes sobre manifestaciones pseudocarsicas en rocas no carbonatadas. Voluntad Hidraulica, 22, 33-35.

Alonso-Zarza, A.M. \& Wright, V.P. 2010. Calcretes.

Anderson, J.L. \& Smith, D.R. 1995. The effects of temperature and $\mathrm{fO}_{2}$ on the Al-in-hornblende barometer. American Mineralogist, 80, 549-559.

Andréfouët, S., Cabioch, G., Flamand, B. \& Pelletier, B. 2009. A reappraisal of the diversity of geomorphological and genetic processes of New Caledonian coral reefs: a synthesis from optical remote sensing, coring and acoustic multibeam observations. Coral Reefs, 28, 691-707, doi: 10.1007/s00338-009-0503-y.

Andréfouët, S. \& Torres-Pullizza, D. 2004. Atlas des récifs coralliens de Nouvelle-Calédonie. IFRECOR Nouvelle-Calédonie, IRD, Nouméa, 1-26.

Augé, T. \& Maurizot, P. 2002. Etude d'un gisement de chromite et de minéralisations en platinoïdes. Partie I - Etude de minéralisations en chromite. Rapport final. BRGM Report, BRGM/RC-51689-FR, 1180.

Avias, J. 1952a. Note sur la genèse des gîtes nickélifères en Nouvelle-Calédonie (secteur central). Report of the session - 19th International Geological congress, Algiers, Sect. XII, 271-272.

Avias, J. 1952b. Sur la formation actuelle de gypse dans certains marais côtiers de la NouvelleCalédonie. Comptes rendus XIXème session. Congrès géologique International, Alger. Section IV. Topographie sous-marine et sédimentation actuelle. Fascicule IV, 7-9.

Avias, J. 1959. Les récifs coralliens de la Nouvelle-Calédonie et quelques-uns de leurs problèmes. Bull. Soc. géol. Fr, 7, 424-430.

Avias, J. 1965. Sur l'origine du gîte de chrome de l'île Hugon (baie de Saint-Vincent), NouvelleCalédonie. Compte-Rendu sommaire des séances de la Société Géologique Française, 9, 301-303.

Avias, J. 1969. Note sur les facteurs contrôlant la genèse et la destruction des gîtes de nickel de la Nouvelle-Calédonie. Importance des facteurs hydrologiques et hydrogéologiques. Comptes Rendus de l'Académie des Sciences, Ser. D, 244-246.

Avias, J. \& Drot, J. 1952. Sur la présence du Rhétien en Nouvelle-Calédonie. C.R. somm. Soc. Géol. Fr. 
Avias, J. \& Coudray, J. 1965. Sur la présence d'éolianites en Nouvelle-Calédonie. Compte Rendu Sommaire de la Société Géologique de France, 10, 327.

Avias, J. \& Coudray, J. 1967. Premiers enseignements apportés par un forage réalisé dans le récif barrière de la Nouvelle-Calédonie. Compte rendu de l'Académie des Sciences, 265, 1867-1869.

Bache, F., Mortimer, N., Sutherland, R., Collot, J., Rouillard, P., Stagpoole, V. \& Nicol, A. 2014. Seismic stratigraphic record of transition from Mesozoic subduction to continental breakup in the Zealandia sector of eastern Gondwana. Gondwana Research, 26, 1060-1078.

Bailly, L., Ambrosi, J.P., Barbarand, J., Beauvais, A., Cluzel, D., Lerouge, C., Prognon, C., Quesnel, F., Ramanaïdou, E., Ricordel-Prognon, C., Ruffet, G., Sevin, B., Wells, M. \& Yans, J. 2014. Projet NICKAL : Typologie des latérites de Nouvelle-Calédonie et facteurs de concentration de $\mathrm{Co}$ et $\mathrm{Ni}$. rapport final, $B R G M / R P-63$ 482, 1-402.

Baltzer, F. 1965. Étude sédimentologique du marais de Mara (côte ouest de la Nouvelle-Calédonie) et de formations quaternaires voisines. Ph D. thesis memoir, Laboratoire de sédimentologie, Orsay, Paris. In: Expédition française sur les récifs coralliens de la Nouvelle-Calédonie. Edition de la fondation Singer-Polignac. Paris 1970, IV, 1-148.

Baltzer, F. \& Dugas, F. 1977. Age of slope breccia and caliche capping the aeolianites in the Baiy of Saint Vincent, West Coast of New Caledonia. International Symposium on Geodynamic in South-West Pacific, Nouméa (New Caledonia), 1976, Technip Ed., Paris, 301-306.

Baltzer, F., Guillon, J.H., Launay, J. \& Trescases, J.J. 1967. Geological and geophysical publications on New Caledonia. New Zealand Journal of Geology and Geophysics, 10, 1275-1279, doi:

10.1080/00288306.1967.10420219.

Beaudou, A.G., Fromaget, M., Podwojewski, P., Bourdon, E., Le Martret, H. \& Blavet, D. 1983. Cartographie typologique des sols. Méthodologie. ORSTOM-Territoire de la Nouvelle-Calédonie et dépendances, 1-31.

Bégot, J., Brière de I'Isle, B., Cabioch, G., Chauvet, A., Chevillon, C., Flamand, B., Lagabrielle, Y., Le Roy, P., Maurizot, P. \& Panché, J.-Y. 2004. Campagne CALGON: sismique-réflexion haute résolution et cartographie multifaisceaux du lagon sud-ouest de Nouvelle-Calédonie.

Bibent, B., Gonord, H. \& Rabinovitch, M. 1972. Observations complémentaires sur un complexe détritique continental de type ferrallitique dans la région de Ouena (Nouvelle-Calédonie). Comptes Rendus de l'Academie des Sciences, Paris, 274, 170-173.

Bird, E.C.F. \& Iltis, J. 1985. New caledonia. In: Bird, E.C.F., Scwartz, M.L. ŽEds.., The World's Coastline. Van Nostrand Reinhold, New York, 995-1002. 
Bitoun, G. \& Récy, J. 1982. Origine et évolution du bassin des Loyauté et ses bordures après la mise en place de la série ophiolitique de Nouvelle-Calédonie: Contribution à l'étude géodynamique du sud-ouest Pacifique. In: ORSTOM (ed.) Contribution à l'étude géodynamique du Sud-Ouest Pacifique. Travaux et Documents de I'ORSTOM. ORSTOM, 147, Paris, 505 - 539.

Black, P.M. 1993. Tectonism, magmatism and sedimentary basin development, Paleozoic to Paleogene, New Caledonia. Geological Society Malaysia Bulletin, 33, 331-341.

Black, P.M., Itaya, T., Ohhira, T., Smith, I.E.M. \& Takagi, M. 1994. Mid-Tertiary magmatic events in New Caledonia: K-Ar dating of boninitic volcanism and granodiorite intrusives. Geoscience reports of Shizuoka University, 20, 49-53.

Blundy, J.D. \& Holland, T.J. 1990. Calcic amphibole equilibria and a new amphibole-plagioclase geothermometer. Contributions to Mineralogy and Petrology, 104, 208-224.

Bonvallot, J. 2012. L'orohydrographie. in: Bonvallot J., Gay J.Ch., Habert H., 2012, Atlas de la Nouvelle-Calédonie Marseille-Nouméa, IRD-Congrès de la Nouvelle-Calédonie, 25-28.

Brothers, R.N. \& Black, N.C. 1973. Tertiary plate tectonics and high-pressure metamorphism in New Caledonia. Tectonophysics, 17, 337-358.

Bucher, K., Stober, I. \& Müller-Sigmund, H. 2015. Weathering crusts on peridotite. Contribution to Mineralogy and Petrology, 169, doi: 10.1007/s00410-015-1146-3.

Burns, R.E., Andrews, J.E., Van der Lingen, G.J., Churkin, M., Davies, J.H., Dumitrica, P., Edwards, A.R., Galehouse, J.S., Kennett, J.P. \& Packham, G.H. 1973. Regional aspects of deep sea drilling in the Southwest Pacific, Lithostratigraphy of Eight Drill Sites in the Southwest Pacific. Preliminary Results of the Deep Sea Drilling Project, 21.

Cabioch, G. 1988. Recifs frangeants de Nouvelle Calédonie (Pacifique Sud Ouest), structure interne et influences de l'eustatisme et de la néotectonique. Thèse Université de Provence-ORSTOM, 291.

Cabioch, G. 2003. Postglacial reef development in the South-West Pacific: case studies from New Caledonia and Vanuatu. Sedimentary Geology, 159, 43-59.

Cabioch, G., Correge, T., Turpin, L., Castellaro, C. \& Recy, J. 1999. Development patterns of fringing and barrier reefs in New Caledonia (southwest Pacific). Oceanologica Acta, 22, 567-578.

Cabioch, G., Montaggioni, L., Thouveny, N., Frank, N., Sato, T., Chazottes, V., Dalamasso, H., Payri, C., Pichon, M. \& Sémah, A.-M. 2008a. The chronology and structure of the western New Caledonian barrier reef tracts. Palaeogeography, Palaeoclimatology, Palaeoecology, 268, 91-105, doi: 10.1016/j.palaeo.2008.07.014. 
Cabioch, G., Montaggioni, L.F. \& Faure, G. 1995. Holocene initiation and development of New Caledonian fringing reefs. Coral Reefs, 14, 131-140.

Cabioch, G., Montevecchi, L. \& Récy, J. 1993. Croissance du récif corallien de l'îlot Amédée et implications structurales sur la formation du lagon Sud-Ouest de Nouvelle-Calédonie (Pacifique SudOuest). Séance spéciale de la Société Géologique de France, Paris, Décembre 1993, 52-53.

Cabioch, G., Recy, J., Jouannic, C. \& Turpin, L. 1996. Contrôle climatique et tectonique de l'édification récifale en Nouvelle-Calédonie au cours du Quaternaire terminal. Bulletin de la Societe Geologique de France, 167.

Cabioch, G., Thomassin, B.A. \& Lecolle, J.F. 1989. Age d'émersion des récifs frangeants holocènes autour de la grande terre de NC.pdf. Comptes Rendus de l'Académie des Sciences, 308, 419-425.

Cabioch, G., Wirrmann, D., Sémah, A.-M., Corrège, T. \& Le Cornec, F. 2008b. Évolution des paléoenvironnements dans le Pacifique lors de la dernière déglaciation: exemples en NouvelleCalédonie et au Vanuatu. Le Journal de la Société des Océanistes, 25-40.

Carroué, J.P., Espirat, J.J. 1967. Carte Géologique à l'échelle du 1 / 50000 et notice explicative: feuille Poya - Plaine des Gaiacs. Territoire de la Nouvelle-Calédonie - Bureau de Recherches Géologiques et Minières. 1-29.

Castellaro, C. 1999. Reconstitutions paléoclimatiques et paléoenvironnementales a' l'Holocène et au Pléistocène terminal en Nouvelle-Calédonie et aux Seychelles (région indo-pacifique):

l'enregistrement par les coraux. Ph.D. thesis, Aix-Marseille University, 1-212.

Chardon, D., Austin, J.A., Cabioch, G., Pelletier, B., Saustrup, S. \& Sage, F. 2008. Neogene history of the northeastern New Caledonia continental margin from multichannel reflection seismic profiles. Comptes Rendus Geoscience, 340, 68-73, doi: 10.1016/j.crte.2007.09.017.

Chardon, D. \& Chevillotte, V. 2006. Morphotectonic evolution of the New Caledonia ridge (Pacific Southwest) from post-obduction tectonosedimentary record. Tectonophysics, 420, 473-491, doi: 10.1016/j.tecto.2006.04.004.

Chardy, P., Chevillon, C. \& Clavier, J. 1988. Major benthic communities of the south west lagoon of New Caledonia. Coral Reefs, 7, 69-75.

Chevalier, J. 1973. Coral reefs of New Caledonia. Biology and geology of coral reefs, 1, 143-167.

Chevillon, C. 1989. Biosédimentologie du grand lagon nord de la Nouvelle-Calédonie, Aix-Marseille II.

Chevillon, C. 1996a. Skeletal composition of modern lagoon sediments in New Caledonia: coral, a minor constituent. Coral Reefs, 15, 199-207. 
Chevillon, C. 1996b. Texture, granulométrie et composition bioclastique des sédiments actuels de l'atoll d'Ouvéa (Iles Loyauté, Nouvelle Calédonie).

Chevillon, C. 2005. Caractérisation des types de fonds et habitats benthiques par système de discrimination acoustique dans le lagon sud-ouest de Nouvelle-Calédonie. Rapport final d'opération ZONECO, 1-74.

Chevillon, C. 2012. Le lagon sud-ouest de la Grande-Terre: Géomorphologie, sédimentologie. in: Bonvallot J., Gay J.Ch., Habert H., 2012, Atlas de la Nouvelle-Calédonie Marseille-Nouméa, IRDCongrès de la Nouvelle-Calédonie, 37-40.

Chevillon, C. \& Clavier, J. 1988. Sedimentological structure of the northern lagoon of New Caledonia. Proceedings of the 6th International Coral Reef Symposium, Australia, 3, 425-430.

Chevillon, C., Clavier, J. \& Garrigue, C. 1992. Preliminary data on the sediments of the Uvea lagoon (New Caledonia).

Chevillotte, V. 2005. Morphogenèse tropicale en contexte épirogénique modéré, exemple de la Nouvelle-Calédonie (Pacifique Sud-Ouest). University of Noumea.

Chevillotte, V., Chardon, D., Beauvais, A., Maurizot, P. \& Colin, F. 2006. Long-term tropical morphogenesis of New Caledonia (Southwest Pacific): Importance of positive epeirogeny and climate change. Geomorphology, 81, 361-375, doi: 10.1016/j.geomorph.2006.04.020.

Chevillotte, V., Douillet, P., Cabioch, G., Lafoy, Y., Lagabrielle, Y. \& Maurizot, P. 2004. Evolution géomorphologique de l'avant pays du Sud-Ouest de la Nouvelle-Calédonie durant les derniers cycles glaciaires. Assises de la recherche française dans le Pacifique, Nouméa, Nouvelle-Calédonie. Poster.

Chevillotte, V., Douillet, P., Cabioch, G., Lafoy, Y., Lagabrielle, Y. \& Maurizot, P. 2005. Evolution géomorphologique de l'avant-pays du Sud-Ouest de la Nouvelle-Calédonie durant les derniers cycles glaciaires. Comptes Rendus Geosciences, 337, 695-701, doi: 10.1016/j.crte.2005.02.008.

Cluzel, D., Aitchison, J.C. \& Picard, C. 2001. Tectonic accretion and underplating of mafic terranes in the Late Eocene intraoceanic fore-arc of New Caledonia (Southwest Pacific): geodynamic implications. Tectonophysics, 340, 23-59, doi: 10.1016/S0040-1951(01)00148-2.

Cluzel, D., Bosch, D., Paquette, J.L., Lemennicier, Y., Montjoie, P. \& Ménot, R.P. 2005. Late Oligocene post-obduction granitoids of New Caledonia : A case for reactivated subduction and slab break-off. The Island Arc, 14, 254-271.

Cluzel, D., Maurizot, P., Collot, J. \& Sevin, B. 2012. An outline of the Geology of New Caledonia ; from Permian - Mesozoic Southeast Gondwanaland active margin to Cenozoic obduction and supergene. Episodes, 72-86. 
Collot, J. 2009. Evolution géodynamique du domaine Ouestoffshore de la Nouvelle-Calédonie et de ses extensions vers la Nouvelle Zélande. Ph.D. thesis, Université de Bretagne occidentale-Brest.

Collot, J., Geli, L., Lafoy, Y., Vially, R., Cluzel, D., Klingelhoefer, F. \& Nouzé, H. 2008. Tectonic history of northern New Caledonia Basin from deep offshore seismic reflection: Relation to late Eocene obduction in New Caledonia, southwest Pacific. Tectonics, 27, 1-20, doi: 10.1029/2008TC002263.

Collot, J., Patriat, M., Etienne, S., Rouillard, P., Soetaert, F., Juan, C., Marcaillou, B., Palazzin, G., Clerc, C. \& Maurizot, P. 2017. Deepwater Fold-and-Thrust Belt Along New Caledonia's Western Margin: Relation to Post-obduction Vertical Motions. Tectonics.

Collot, J., Rigolot, P. \& Missegue, F. 1988. Geologic structure of the northern New Caledonia Ridge, as inferred from magnetic and gravity anomalies. Tectonics, 7, 991-1013.

Collot, J., Rouillard, P., Juan, C., Laenault, Y., Patriat, M., Privat, A. \& Maurizot, P. 2013. Rapport de mission de la campagne IPO (Investigating Post Obduction Deposits) à bord du N/O Alis du 1er au 18 août 2012. Geological Survey of New Caledonia Report 2013 (1), 1-139.

Collot, J.Y., Malahoff, A., Recy, J., Latham, G. \& Missegue, F. 1987. Overthrust emplacement of New Caledonia Ophiolite: Geophysical evidence. Tectonics, 6, 215-232, doi: 10.1029/TC006i003p00215.

Corrège, T., Delcroix, T., Récy, J., Beck, W., Cabioch, G. \& Le Cornec, F. 2000. Evidence for stronger El Niño-Southern Oscillation (ENSO) events in a mid-Holocene massive coral. Palaeoceanography, 15, 465-470.

Corrège, T., Gagan, M.K., Beck, J.W., Burr, G.S., Cabioch, G. \& Le Cornec, F. 2004. Interdecadal variation in the extent of south tropical waters during the Younger Dryas event. Nature, 428, 927929.

Corrège, T., Quinn, T., Delcroix, T., Le Cornec, F., Récy, J. \& Cabioch, G. 2001. Little Ice Age sea surface temperature variability in the southwest tropical Pacific. Geophysical Research Letters, 28, 34773480 .

Cotillon, P., Liu, J.D. \& Pannetier, W. 1992. Dynamique de la sedimentation quaternaire sur les pentes et dans les bassins au large de la Nouvelle-Caledonie (SW Pacifique); comparaison avec d'autres systemes de depots carbonates actuels et anciens. Bulletin de la Société Géologique de France, 163, 241-254.

Coudray, J. 1976. Recherches sur le Néogène et le Quaternaire marins de la Nouvelle Calédonie. Contribution de l'étude sédimentologique à la connaissance de l'histoire géologique post-éocène. Expédition française sur les récifs coralliens de la Nouvelle-Calédonie. Fondation Singer-Polignac, Université des Sciences et Techniques du Languedoc, Montpellier, 8, 183. 
Coudray, J. 1969. Observations nouvelles sur les formations miocènes et post-miocènes de la région de Népoui (Nouvelle-Calédonie): précisions lithologiques et preuves d'une tectonique «récente» sur la côte sud-ouest de ce Territoire. R. Acad. Sci, 269, 1599-1602.

Coudray, J. 1977a. The main events of the sedimentary and structural history of New Caledonia from the Oligocene to the present day. International Symposium on Geodynamics in southwest Pacific, Noumea - New Caledonia. Technip Ed., 2, 217-227.

Coudray, J. 1977b. Recherche sur le Quaternaire marin de la Nouvelle-Calédonie. Contribution al'étude des récifs coralliens et des éolianites associées ala reconstitution de l'histoire climatique et structurale. Bull. Ass. Fr. Et. Quat, 1, 331-340.

Coudray, J. \& Cussey, R. 1973. Analyse des conditions de depot de la série récifale plioquaternaire traversée par le sondage Ténia (côte sud-ouest de la Nouvelle-Calédonie). Comptes Rendus de I'Académie des Sciences, Paris, 1977-1980.

Daniel, J., Dugas, F., Dupont, J., Jouannic, C., Launay, J., Monzier, M. \& Récy, J. 1976. La zone charnière Nouvelle-Calédonie/Ride de Norfolk (SW Pacifique), résultats de dragages et interprétation. Cah. ORSTOM, ser. Geol. VIII, 95-105.

Darwin, C., 1842. The structure and distribution of coral reefs. Smith, Elder and Co., London. 1-214.

Davis, W.M. 1899. La pénéplaine. Armand Colin.

Davis, W.M. 1925. Les côtes et les récifs coralliens de la Nouvelle-Calédonie. Annales de Géographie, 34, 244-269; 322-359; 423-441; 521-556,

De Boer, B., Van de Wal, R.S.W., Lourens, L.J. \& Bintanja, R. 2012. Transient nature of the Earth's climate and its implications on the interpretation of benthic d180 records. Palaeogeography, Palaeoclimatology, Palaeoecology, 4, 335-336.

Debenay, J. 1987. Repartition des sediments carbonates et relation avec l'hydrodynamisme dans un environnement recifal complexe; le lagon sud-ouest de Nouvelle-Caledonie. Bulletin de la Societe Geologique de France, 3, 769-776.

Degaugue-Michalski, F.M. 1993. Croissance et évolution d'édifices récifaux du Pacifique occidental (Nelle-Calédonie, Chesterfield) à l'Holocène et au Pléistocène. These Doct Univ Aix-Marseille I, 1-227.

Dubois, J., Launay, J. \& Recy, J. 1974. Uplift movements in New Caledonia-Loyalty Islands area and their plate tectonics interpretation. Tectonophysics, 24, 133-150.

Dubois, J., Launay, J., Récy, J. \& Marshall, J. 1977. New Hebrides trench: subduction rate from associated lithospheric bulge. Canadian Journal of Earth Sciences, 14, 250-255. 
Dugas, F. 1974. Les faciès littoraux du Pléitocène à l'actuel de la Baie de Saint-Vincent. Cahier ORSTOM, série Géologie, VI, 63-66.

Dugas, F., Debenay, J.P., Baltzer, F., Coudray, J., Magnier, A. \& Plaziat, J.C. 1982. Carte sédimentologique et carte annexe du lagon de Nouvelle-Calédonie à 1/50 000 : feuille Nouméa. Notice Explicative, No 95. Paris (FRA) : ORSTOM, Office de la recherche scientifique et technique outre mer, 1-48.

Dugas, F., Debenay, J.P., Chevallier, J.P., Denizot, M., Douib, A. \& Salvat, B. 1980a. Carte sédimentologique et carte annexe du lagon de Nouvelle-Calédonie à 1/50 000 : feuille La Tontouta. Notice Explicative, No 86. Paris (FRA) : ORSTOM, Office de la recherche scientifique et technique outre mer, 1-45.

Dugas, F., Debenay, J.P., Dandonneau, Y. \& Rivaton, J. 1978. Carte sédimentologique et carte annexe du lagon de Nouvelle Calédonie à 1/50 000 : feuille Mont Dore. Notice Explicative, No 76. Paris (FRA) : ORSTOM, Office de la recherche scientifique et technique outre mer, 1-23.

Dugas, F., Debenay, J.P., Fourmanoir, P., Launay, J. \& Rougerie, F. 1981. Carte sédimentologique et carte annexe du lagon de Nouvelle-Calédonie à 1/50 000 : feuille Prony.Notice Explicative, No 91. Paris (FRA) : ORSTOM, Office de la recherche scientifique et technique outre mer, 1-38.

Dugas, F., Ville, P. \& Coudray, J. 1980b. Etude sismique du lagon sud-ouest de la Nouvelle-Calédonie (Sud-Ouest Pacifique). Paléomorphologies successives et comportement,au Quaternaire supérieur du littoral de l'île. Compte rendu de l'Académie des Sciences, 290, 963-966.

Emery, D. 1996. Carbonate systems. In: Emery, D., Myers, K.J. (Eds.), Sequence Stratigraphy. Blackwell Science Ltd, 211-237.

Exon, N., Hill, P., Lafoy, Y., Heine, C. \& Bernardel, G. 2006. Kenn Plateau off northeast Australia: a continental fragment in the southwest Pacific jigsaw. Australian Journal of Earth Sciences, 53, 541564.

Exon, N., Quilty, P., Lafoy, Y., Crawford, A. \& AUZENDE, J.M. 2004. Miocene volcanic seamounts on northern Lord Howe Rise: lithology, age and origin. Australian Journal of Earth Sciences, 51, 291-300.

Falvey, D.A. 1979. Paleomagnetic Results from the New Caledonia Laterites. Preliminary Report. University of Sydney, unpublished report.

Fernandez, J.-M., Ouillon, S., Chevillon, C., Douillet, P., Fichez, R. \& Gendre, R.L. 2006. A combined modelling and geochemical study of the fate of terrigenous inputs from mixed natural and mining sources in a coral reef lagoon (New Caledonia). Marine Pollution Bulletin, 52, 320-331. 
Fisher, J.L., Cantrill, D.J., Cluzel, D., Garrouste, R., Grandcolas, P., Maurizot, P., Munzinger, J. \& Leslie, A.B. 2015. A Miocene flora from New Caledonia and its implications for understanding diversity and paleoclimate. Abstract to the Geological Society of America (GSA) Annual Meeting in Baltimore, Maryland, USA (1-4 November 2015). Paleontology: Life on Land and in the Oceans: Paleoclimate and Paleoenvironmental Reconstructions (Posters).

Flamand, B. 2006. Les pentes externs du récif barrière de la Grande Terre de Nouvelle-Calédonie: morphologie, lithologie, contrôle de la tectonique et de l'eustatisme. Ph.D Thesis. Université de Bretagne Occidentale, 1-240.

Flamand, B., Cabioch, G., Payri, C. \& Pelletier, B. 2008. Nature and biological composition of the New Caledonian outer barrier reef slopes. Marine Geology, 250, 157-179, doi: 10.1016/j.margeo.2007.12.002.

Foan, A.G. 2015. The history of the New Caledonia Barrier Reef over the last 1.2 Myrs: links with regional palaeoceanography and palaeoclimate. PhD thesis. The university of Edinburgh.

Folcher, N. 2016. Contrôles géodynamiques et climatiques du système fluvio-lacustre de NouvelleCalédonie. Conséquences sur la formation des gidements de nickel latéritiques. Ph.D.

Folcher, N., Ricordel-Prognon, C., Sevin, B., Maurizot, P., Cluzel, D. \& Quesnel, F. 2014. Neogene weathering and terrestrial sedimentation in southern New Caledonia; inference on post-obduction tectonics and climate change. Geophysical Research abstracts, European Geoscience Union General assembly, 16.

Folcher, N., Sevin, B., Maurizot, P. \& Cluzel, D. 2013. Iron-rich terrestrial sediments, a new tool for understanding the post-obduction history of New-Caledonia (Southwest Pacific). Communication to International Association of Sedimentology.

Folcher, N., Sevin, B., Quesnel, F., Lignier, V., Allenbach, M., Maurizot, P. \& Cluzel, D. 2015. Neogene terrestrial sediments: a record of the post-obduction history of New Caledonia. Australian Journal of Earth Sciences, 62, 479-492.

Fontes, J.C., Launay, J., Monzier, M. \& Recy, J. 1977. Genetic hypothesis on the ancient and recent reef complexes in New Caledonia. International Symposium on Geodynamic in South-West Pacific, Nouméa (New Caledonia), 1976, Technip Ed., Paris, 289-300.

Frank, N., Turpin, L., Cabioch, G., Blamart, D., Tressens-Fedou, M., Colin, C. \& Jean-Baptiste, P. 2006. Open system U-series ages of corals from a subsiding reef in New Caledonia: Implications for sea level changes, and subsidence rate. Earth and Planetary Science Letters, 249, 274-289.

Freyssinet, P., Butt, C.R.M. \& Morris, R.C. 2005. Ore-Forming Processes Related to Lateritic Weathering. Economic Geology, 100th Anniversary Volume, 681-722. 
Fritsch, E. 2012. Les sols. PI. 15. in: Bonvallot J., Gay J. - Ch., Habert É. (coord.), 2012, Atlas de la Nouvelle-Calédonie, Marseille-Nouméa, IRD-congrès de la Nouvelle-Calédonie, 272 pages, 73-76.

Fritsch, E., Juillot, F., Dublet, G., Fandeur, D., Fonteneau, L., Martin, E., Auzente, A.L., Morin, G., Robert, J.L., Galoisy, L., Calas, G., Grauby, O., Boulvais, P. \& Cathelineau, M. 2014. Analyse fine de minerais latéritiques (approches pétrographique, minéralogique, géochimique et isotopique). CNRT, Rapport final, 1-131.

Garcin, M., Vendé-Leclerc, M., Maurizot, P., LeCozannet, G., Robineau, B., Nicolae-Lerma, A. 2016. Lagoon islets as indicators of recent environmental changes in the South Pacific - The New Caledonian example. Continental Shelf Research, 122, 120-140, doi: 10.1016/j.csr.2016.03.025.

Genna, A., Bailly, L., Lafoy, Y. \& Augé, T. 2005a. Les karsts latéritiques de Nouvelle-Calédonie. Karstologia, 19-28.

Genna, A., Maurizot, P., Lafoy, Y. \& Augé, T. 2005b. Contrôle karstique de minéralisations nickélifères de Nouvelle-Calédonie. Comptes Rendus Geoscience, 337, 367-374, doi: 10.1016/j.crte.2004.09.013.

Gonord, H. \& Trescases, J.-J. 1970. Observations nouvelles sur la formation post-miocène de Mueo (côte ouest de la Nouvelle-Calédonie): conséquences paléogéographiques et structurales. Comptes Rendus de l'Académie des Sciences. Série D: Sciences Naturelles, 270, 584-587.

Gubler, Y. \& Pomeyrol, R. 1948. Existence de Néogène marin en Nouvelle-Calédonie. Comptes Rendus de l'Académie des Sciences, 226, 1292-1293.

Guilcher, A. 1965. Grand Récif Sud, Récifs et lagon de Tuo. In: Fond. Singer-Polignac (Eds.), Expédition française sur les récifs Nouvelle-Calédonie, Paris, 1, 137-239.

Guilcher, A. 1988. Coral Reef Geomorphology. John Wiley \& Sons, New York, 1-228.

Guillon, J.-H., Trescases, J.-J., Prinzhofer, A., Launay, J., Moussu, H. \& Frimigacci, D. 1986. Notice explicative sur la feuille lle des Pins.

Guillon, J.H. \& Trescases, J.J. 1975. Carte géologique de la Nouvelle-Calédonie à 1/50 000 et notce explicative, Saint-Louis. BRGM.

Guillon, J.H. \& Trescases, J.J. 1976. Carte géologique à l'échelle du 1 / 50000 et notice explicative, feuille Saint-Louis. Territoire de la Nouvelle-Calédonie - Bureau de Recherches Géologiques et Minières, 1-42.

Guy, B. 1976. Nouvelles observations sur les formations du Gwa N'Doro (Nouvelle-Calédonie). International Symposium on Geodynamic in South-West Pacific, Nouméa (New Caledonia), 1976, Technip Ed., Paris, 283-288. 
Guy, B., Paris, J.P. \& Prinzhofer, A. 1979. Carte Géologique à l'échelle du 1 / 50000 et notice explicative: feuille Kouaoua. Territoire de la Nouvelle-Calédonie - Bureau de Recherches Géologiques et Minières, 1-40.

Holland, T. \& Blundy, J. 1994. Non-ideal interactions in calcic amphiboles and their bearing on amphibole-plagioclase thermometry. Contributions to Mineralogy and Petrology, 116, 433-447.

Hope, G. 2001. Environmental change in the Late Pleistocene and later Holocene at Wanda Site, Soroako, South Sulawesi, Indonesia. Palaeogeography Palaeoclimatology Palaeoecology, 171, 129145, doi: 10.1016/S0031-0182(01)00243-7.

Hope, G. 2015. Extended vegetation histories from ultramafic karst depressions. Australian Journal of Botany, 63, 222-233, doi: 10.1071/BT14283.

Hope, G. \& Pask, J. 1998. Tropical vegetational change in the late Pleistocene of New Caledonia. Palaeogeography, Palaeoclimatology, Palaeoecology, 142, 1-21.

Iltis, J. 1989. L'alluvionement en Nouvelle-Calédonie. Etude des systèmes de terrasses fluviatiles et quaternaires. Résumé de thèse. Strasbourg ULP, 1-7.

Jeanpert, J., Genthon, P., Join, J.L., Vendé-Leclerc, M., Sérino, J. \& Maurizot, P. 2014. Dolines on ultramaic rocks : the case of the Southern Grande Terre of New Caledonia (SW Pacific). AGU, Fall Meeting, posters. Paper number: H43B-0968.

Jeanpert, J., Genthon, P., Maurizot, P., Folio, J.L., Vendé-Leclerc, M., Sérino, J., Join, J.L. \& Iseppi, M. 2016. Morphology and distribution of dolines on ultramafic rocks from airborne LiDAR data: the case of southern Grande Terre in New Caledonia (SW Pacific). Earth Surface Processes and Landforms, doi: 10.1002/esp.3952.

Join, J.-L., Robineau, B., Ambrosi, J.-P., Costis, C. \& Colin, F. 2005. Système hydrogéologique d'un massif minier ultrabasique de Nouvelle-Calédonie. Comptes-Rendus Géoscience, 337.

Kennett, J.P., von der Borch, C.C., Baker, P.A., Barton, C.E., Boersma, A., Caulet, J.P., Dudley, W.C., Gardner, J.V., Jenkins, D.G., Lohman, W.H., Martini, E., Merrill, R.B., B., R., Morin, R.H., H., R., Nelson, C.S., Robert, C., Srinivasan, M.S., Stein, R., Takeuchi, A. \& Blakeslee, J.H. 1986. Site 588; Lord Howe Rise, $26^{\circ} \mathrm{S}$. Initial reports of the Deep Sea Drilling Project, 90, 139-252, doi:

10.2973/dsdp.proc.90.104.1986.

Klingelhoefer, F., Lafoy, Y., Collot, J., Cosquer, E., Géli, L., Nouzé, H. \& Vially, R. 2007. Crustal structure of the basin and ridge system west of New Caledonia (southwest Pacific) from wide-angle and reflection seismic data. Journal of Geophysical Research, 112, doi: 10.1029/2007jb005093. 
Lacroix, A. 1905. Sur une pseudomorphose d'insecte en nouméite (Nouvelle-Calédonie). Bulletin de la Société française de Minéralogie. Paris, XXVI, 303, http://catalogue.bnf.fr/ark:/12148/cb307104315.

Lafoy, Y., van de Beuque, S., Missegue, F., Nercessian, A., Bernadel, G., 1998. Campagne de sismique multitrace entre la marge Est Australienne et le Sud de l'arc des Nouvelles-Hébrides - Rapport de la campagne RIG SEISMIC 206 (21 avril - 24 mai 1998) - Programme FAUST, pp. 1-40.

Lafoy, Y., Auzende, J.-M., Smith, R. \& Labails, C. 2000. Évolution géologique post-Pléistocène moyen du domaine lagonaire Néo-Calédonien méridional. Comptes Rendus de l'Académie des Sciences-Series IIA-Earth and Planetary Science, 330, 265-272.

Lagabrielle, Y. \& Chauvet, A. 2008. The role of extensional tectonics in shaping Cenozoic NewCaledonia. Bulletin de la Societe Geologique de France, 179, 315-329.

Lagabrielle, Y., Chauvet, A., Ulrich, M. \& Guillot, S. 2013. Passive obduction and gravity-driven emplacement of large ophiolitic sheets: The New Caledonia ophiolite (SW Pacific) as a case study? Bulletin de la Societe Geologique de France, 184, 545-556.

Lagabrielle, Y., Maurizot, P., Lafoy, Y., Cabioch, G., Pelletier, B., Régnier, M., Wabete, I. \& Calmant, S. 2005. Post-Eocene extensional tectonics in Southern New Caledonia (SW Pacific): Insights from onshore fault analysis and offshore seismic data. Tectonophysics, 403, 1-28.

Latham, M. 1977. On geomorphology of northern and western New Caledonian ultramafic massifs. International Symposium on Geodynamics of the South-West Pacific. Noumea, New Caledonia, 235244.

Latham, M. 1986. Altération et pédogenèse sur roches ultrabasiques en Nouvelle-Calédonie, Genèse et évolution des accumulations du fer et de silice en relation avec la formation du modelé. Ph $D$. thesis, Université de Dijon, Coll. Études et thèse, Orstom, 331.

Latham, M., Quantin, P. \& Aubert, G. 1978. Etude des sols de la Nouvelle-Calédonie. Nouvel essai sur la classification, la caractérisation, la pédogenèse et les aptitudes des sols de Nouvelle-Calédonie. Carte pédologique de la Nouvelle-Calédonie à 1 / 100 000. ORSTOM, Paris, 1-138.

Launay, J. 1970. Etude des sediments de la Baie de la Dumbéa Nouvelle-Calédonie, résultats préliminaires. ORSTOM (Eds.), Centre de Nouméa, 1-7.

Launay, J. 1971. La sédimentation en Baie de Dumbéa (côte ouest - Nouvelle Calédonie). ORSTOM (Eds.), Centre de Nouméa, 1-48.

Launay, J. 1972. La sédimentation en Baie de Dumbéa, côte ouest, Nouvelle Calédonie. Cahier ORSTOM (Eds.), Géologie, IV, 25-51. 
Launay, J. \& Récy, J. 1972. Variations relatives du niveau de la mer et néotectonique en NouvelleCalédonie au Pléistocène supérieur et à 1'Oligocène. Revue de Géographie Physique et de Géologie Dynamique, XIV, 47-66.

Le Bas, M.J., Lemaitre, R.W., Streckeisen, A. \& Zanettin, B. 1986. A chemical classification of volcanic rocks based on the Total Alkali Silica Diagram. Journal of Petrology, 27, 745-750.

Le Berre, P. 1990. Inventaire des roches et minéraux industriels de la Province Nord (NouvelleCalédonie); étude technico-économique préliminaire. BRGM Report, R.31 482 NCL 4S 90.

Le Berre, P. 1991. Inventaire des roches et minéraux industriels de la Province Nord, recherche de gisements de roches ornementales. BRGM Report, R 34457.

Le Berre, P. \& Maurizot, P. 1992. Reconnaissnace géologique de matèriaux pour ciment dans la région de Népoui. A2EP internal report.

Le Roy, P., Cabioch, G., Monod, B., Lagabrielle, Y., Pelletier, B. \& Flamand, B. 2008. Late Quaternary history of the Nouméa lagoon (New Caledonia, South West Pacific) as depicted by seismic stratigraphy and multibeam bathymetry. Palaeogeography, Palaeoclimatology, Palaeoecology, 270, 29-45, doi: 10.1016/j.palaeo.2008.08.012.

Lecolle, J. \& Cabioch, G. 1988. La limite Holocene-Pleistocene dans le recif frangeant Ricaudy (Nouvelle-Caledonie). Geochronologie, facies et diagenese. Implications eustatiques et neotectoniques. Marine Geology, 81, 241-260.

Lecolle, J.F. 1991. Etude des faciès sédimentaires et diagénétiques de trois sondages de la côte sudest et du lagon néocalédonien. Géodynamique, 6, 141-175.

Lillie, A.R. \& Brothers, R.N. 1970. The geology of New Caledonia. New Zealand Journal of Geology and Geophysics, 13, 145-183, doi: 10.1080/00288306.1970.10428210.

Lliboutry, L. 1969. Sea.floor spreading, continental drift and lithosphere sinking with an asthenosphere at melting point. Journal of Geophysical Research, 74, 6525-6540.

Locatelli, E.R. 2013. The exceptional preservation of leaves in iron-rich sediments from Oceania. Abstracts with Programs - Geological Society of America (GSA) : Boulder, CO, United States, 45, 455.

Loffler, E. 1978. Karst features in igneous rocks in Papua New Guinea. In: Landform evolution in Australasia. (Eds JL Davies, MAJ Williams). Australian National University Press: Canberra, 238-249.

Marker, A., Friedrich, G., Carvalho, A. \& Melfi, A. 1991. Control of the distribution of Mn, Co, Zn, Zr, Ti and REEs during the evolution oflateritic covers above ultramafic complexes. Journal of Geochemical Exploration, 40, 361-383. 
Martin, E. 2011. Transferts de matière dans les processus de formation de minéralisations nickélifères en Nouvelle Calédonie. Rapport de stage de Master GPRE. CNRT. Nancy G2R, 1-42.

Maurizot, P. \& Bouysse, P. 1989. Recherche de gisements de sable et de méthodes d'extraction pour l'amélioration des plages dans la zone de Nouméa. Bureau de Recherches Géologiques et Minières, Réf. 89 NCL 167, 1-45.

Maurizot, P., Cabioch, G., Fournier, F., Leonide, P., Sebih, S., Rouillard, P., Montaggioni, L., Collot, J., Martin-Garin, B., Chaproniere, G., Braga, J.C. \& Sevin, B. 2016. Post-obduction carbonate system development in New Caledonia (Népoui, Lower Miocene). Sedimentary Geology, 331, 42-62, doi: 10.1016/j.sedgeo.2015.11.003.

Maurizot, P. \& Lafoy, Y. 1999. Cartographie des aléas naturels (Mouvements de terrain, érosion) dans le Territoire de Nouvelle-Calédonie, Zone de Tontouta. BRGM Report, BRGM R 40 776, 1-31.

Maurizot, P. \& Lafoy, Y. 2004a. Cartographie des formations superficielles et des aléas mouvements de terrain en Nouvelle-Calédonie - Zone de Kouaoua. BRGM Report, BRGM/RP 53 097-FR, 1-30.

Maurizot, P. \& Lafoy, Y. 2004b. Notice explicative, Carte géologique de Nouvelle- Calédonie (1 / 50 000), feuille Ouvéa, îles Loyauté. BRGM Report/RP52 905 - FR.Service Géologique de NouvelleCalédonie. Bureau de Recherches Géologiques et Minières, 1-75, https://dimenc.gouv.nc/sites/default/files/download.

Maurizot, P., Lafoy, Y., Brière de I'Isle, B. \& Marcangeli, Y. 2004. Cartographie des formations superficielles et des aléas mouvements de terrain en Nouvelle-Calédonie: Zone de Yaté. Rapport BRGM RP - 52497.

Maurizot, P., Lafoy, Y. \& Poupée, M. 2002a. Cartographie des formations superficielles et des aléas mouvements de terrain en Nouvelle-Calédonie: Zone de Goro. BRGM Report, BRGM RP-51 623, 1-44.

Maurizot, P., Lafoy, Y., Poupée, M. \& Vendé-Leclerc, M. 2002b. Cartographie des formations superficielles et des aléas mouvements de terrain en Nouvelle-Calédonie: Zone de Prony. Rapport BRGM RP - 53098.

Maurizot, P., Rouet, I., Robineau, B., Allenbach, M. \& Parisot, J.C. 2007. Mécanismes fondamentaux des mouvements de terrain dans les massifs ultrabasiques de Nouvelle-Calédonie. BRGM Report, BRGM RP -55 041 - FR, 1-49.

Maurizot, P. \& Rouillard, P. 2015. Campagne IPOD, Etude des dragages. Rapport d'avancement. Geological Survey of New Caledonia Report 2013 (1), 1-27. 
Maurizot, P., Sevin, B., Mengin, M. \& Marcalliou, B. 2015. Sondage S2 Népoui, Rapport de mission. Rapport SGNC N 01 (Accompagné de 2 annexes : Sondage S2b. Népoui Annexes et Sondage S2c Népoui Annexes), 1-67.

McDougall, I. \& Duncan, R.A. 1988. Age progressive volcanism in the Tasmantid Seamounts. Earth and Planetary Science Letters, 89, 207-220.

Mcfadden, P.L. \& McElhinny, M.W. 1988. The combined analysis of remagnetization circles and direct observations in palaeomagnetism. Earth Planet. Sci. Lett., 87.

Milankovitch, M.M. 1920. Théorie mathématique des phénomènes thermiques produits par la radiation solaire. Gauthier-Villars,, Zagreb, Paris.

Montaggioni, L.F., Cabioch, G., Thouveny, N., Frank, N., Sato, T. \& Sémah, A.-M. 2011. Revisiting the Quaternary development history of the western New Caledonian shelf system: From ramp to barrier reef. Marine Geology, 280, 57-75, doi: 10.1016/j.margeo.2010.12.001.

Montjoie, P. 1999. Les granitoides miocènes de Nouvelle-Calédonie; produits d'une subduction ou témoins d'une croûte infra-nappe ophiolitique. . Master thesis Université Jean Monnet Saint Etienne France.

Moretti, I. \& Turcotte, D.L. 1985. A model for erosion, sedimentation, and flexure with application to New Caledonia. Journal of Geodynamics, 3, 155-168.

Morley, C., King, R., Hillis, R., Tingay, M. \& Backe, G. 2011. Deepwater fold and thrust belt classification, tectonics, structure and hydrocarbon prospectivity: A review. Earth-Science Reviews, 104, 41-91.

Mortimer, N., Gans, P., Meffre, S., Martin, C., Seton, M., Williams, S., Turnbull, R., Quilty, P., Micklethwaite, S. \& Timm, C. 2018. Regional volcanism of northern Zealandia: post-Gondwana breakup magmatism on an extended, submerged continent. Geological Society, London, Special Publications, 463, 199-226.

Mortimer, N., Gans, P.B., Palin, J.M. \& Herzer, R.H. 2014. Eocene and Oligocene basins and ridges of the Coral Sea-New Caledonia region: tectonic link between Melanesia, Fiji and Zealandia. Tectonics, 33, 1386-1407, doi: 10.1002/2014TC003598.

Müller, R.D., Gaina, C., Tikku, A., Mihut, D., Cande, S.C. \& Stock, J.M. 2000. Mesozoic/Cenozoic tectonic events around Australia. The history and dynamics of Global Plate Motions, 161-188.

Neumann, A.C. \& Macintyre, I. 1985. Reef response to sea level rise : keep-up, catch-up or giveup. Proceedings of the 5th International Coral Reef Congress 3, 3, 105-110. 
Nunez, J.A., Korin, Z., Finko, V.I. \& Formell Cortina, F. 1967. Notas preliminares acerca del carso en peridotita, Sierra de Moa, Oriente. Review of Geology. Cuba, 1, 5-28.

Orloff, O. 1968. Etude géologique et géomorphologique des massifs d'ultrabasites compris entre Houailou et Canala (Nouvelle-Calédonie), Faculté des Sciences de Montpellier.

Orloff, O. \& Gonord, H. 1968. Note préliminaire sur un nouveau complexe sédimentaire continental situé sur le massif du Goa N' Doro el de Kadjitra (régions côtières à l'Est de la Nouvelle-Calédonie), définition de la formation et conséquences de cette découverte sur l'âge des fractures majeures récemment mises en évidence dans les mêmes régions. Comptes Rendus de l'Académie des Sciences, 267, 5-8.

Othman, D.B., White, W.M. \& Patchett, J. 1989. The geochemistry of marine sediments, island arc magma genesis, and crust-mantle recycling. Earth and Planetary Science Letters, 94, 1-21.

Otten, M.T. 1984. The origin of brown hornblende in the Artfjället gabbro and dolerites. Contributions to Mineralogy and Petrology, 86, 189-199.

Pacheco, R.R., Fabregat, S. \& Dias-Martinez, R. 2002. El dessarollo del karst en rocas no carbonatadas: el ejemplo de las rocas ultamaficas serpentinizadas en Cuba. In: Carraco, F., Duran, J.L., y Andreo, B. (Eds) Karst and Environment, 295-304.

Pacheco, R.R., Fabregat, S. \& Días-Martínez, R. 2003. Karstification in ultramafic rocks of Cuba. Abstract International Geological Correllation Program 448 Newsletter 2003.

Pannetier, W. 1990. Enregistrement de l'eustatisme dans les sédiments quaternaires du bassin des Loyauté (Nouvelle-Calédonie, Sud-Ouest Pacifique). Lyon 1.

Paquette, J.L. \& Cluzel, D. 2006. U-Pb zircon dating of post-obduction volcanic-arc granitoids and a granulite-facies xenolith from New Caledonia. Inference on Southwest Pacific geodynamic models. International Journal of Earth Sciences (Geologische Rundschau), 96, 613-622, doi: 10.1007/s00531006-0127-1.

Paris, J.P. 1981. Géologie de la Nouvelle-Calédonie. Mémoire du Bureau de Recherche Géologique et Minière, 113, 1-279.

Patriat, M., Collot, J., Etienne, S., Poli, S., Clerc, C., Mortimer, N., Pattier, F. \& Juan, C. 2017. New Caledonia obducted Peridotite Nappe, offshore extent and implications for obduction and postobduction processes. Tectonics, 37, 1-20, doi: 10.1002/2017TC004722.

Pattier, F., Patriat, M., Collot, J., Etienne, S., Rouillard, P. \& Laurent, E. 2015. Plio-Pleistocene MTCs of the Fairway Basin (Offshore New Caledonia): Morphology and potential triggering mechanisms. . 7th International Symposium on Submarine Mass Movements and their consequences. 1-4 Nov., Mac's Function Center, Wellington. 
Payri, C.E. \& Cabioch, G. 2004. The systematics and significance of coralline red algae in the rhodolith sequence of the Amédée 4 drill core (Southwest New Caledonia). Palaeogeography,

Palaeoclimatology, Palaeoecology, 204, 187-208.

Pearce, J.A. 1982. Trace element characteristics of lavas from destructive plate boundaries. Orogenic andesites and related rocks, 528-548.

Pearce, J.A., Harris, N.B.W. \& Tindle, A.G. 1984. Trace element discrimination diagrams for the tectonic interpretation of granitic rocks. Journal of Petrology. 25, 4, 956-983.

Pelletier, B., Chevillon, C., Menou, J.L., Butscher, J., Folcher, E., Geoffray, C., Bore, J.M., Panché, J.Y. \& Perrier, J. 2006. Plongées, forage et cartographie Baie du Prony et Banc Gail, lagon Sud de NouvelleCalédonie, NO, ALIS, 13-17 juin 2004 et cartographie baie 25 du Prony NO, ALIS, 25-26 septembre 2005,. Internal Report IRD.

Pelletier, B., Juffroy, F., Flamand, B. \& Perrier, J. 2012. La bathymétrie des marges de la Grande-Terre et des îles Loyauté. in: Bonvallot J., Gay J.Ch., Habert H., 2012, Atlas de la Nouvelle-Calédonie Marseille-Nouméa, IRD-Congrès de la Nouvelle-Calédonie, 33-36.

Piroutet, M. 1917. Etude stratigraphique sur la Nouvelle-Calédonie. Ph D. thesis memoir, Université de Paris.

Podwojewski, P. 1988. Les vertisols de Nouvelle-Calédonie. Cahier ORSTOM, série Pédologie, XXIV, 279-301.

Podwojewski, P. 1992. Les vertisols à gypse de Nouvelle-Calédonie dans leur environnement pédologique. Ph D. thesis memoir, Université Louis Pasteur de Strasbourg.

Podwojewski, P. 1993. Mise en évidence d'une source détritique ultrabasique dès l'Eocène moyen dans les flyschs du bassin de Nouméa, Nouvelle-Calédonie. Comptes Rendus de l'Académie des Sciences, 316, série II, 1423-1430.

Podwojewski, P. 1994. The origin of gypsum in vertisols in New Caledonia determinated by isotopics characteristics of sulphur. Geoderme, 63, 179-195.

Podwojewski, P. 1995. The occurrence and interpretation of carbonate and sulfate minerals in a sequence of Vertisols in New Caledonia. Geoderma, 65, 223-248.

Prognon, C., Sevin, B., Folcher, N., Maurizot, P., Cluzel, D. \& Quesnel, F. 2014a. Synthesis of ages obtained by paleomagnetism on ferricretes and iron-rich sediments of New Caledonia. Implications on the morphogenesis of Grande-Terre. 24ème Réunion des Sciences de la Terre: RST 2014.

Prognon, C., Sevin, B., Maurizot, P., Alizert, L., Cluzel, D. \& Quesnel, F. 2014b. Etudes pétrographiques des cuirasses latéritiques et sédiments ferrugineux de Nouvelle Calédonie : une clé pour interpréter 
les datations par paléomagnétisme. 24ème Réunion des Sciences de la Terre : RST 2014, Oct 2014, Pau, France.

Quesnel, B., Boulvais, P., Gautier, P., Cathelineau, M., John, C.M., Dierick, M., Agrinier, P. \& Drouillet, M. 2016. Paired stable isotopes $(\mathrm{O}, \mathrm{C})$ and clumped isotope thermometry of magnesite and silica veins in the New Caledonia Peridotite Nappe. Geochimica et Cosmochimica Acta, doi:

10.1016/j.gca.2016.03.021.

Quesnel, B., Gautier, P., Boulvais, P., Cathelineau, M., Maurizot, P., Cluzel, D., Ulrich, M., Guillot, S., Lesimple, S. \& Couteau, C. 2013a. Syn-tectonic, meteoric water-derived carbonation of the New Caledonia peridotite nappe. Geology, 2-5, doi: 10.1130/G34531.1.

Quesnel, F., Barbarand, J., Sevin, B., Ricordel-Progon, C., Maurizot, P. \& Gautheron, C. 2012. Can we use the planation surface concept to reconstruct the morphogenesis of New Caledonia? First low temperature thermochronological data. 34t International Geological Congress, Aug 2012, Brisbane, Australia, GC126668.

Quesnel, F., Maurizot, P., Lucien, K., Ricordel-Prognon, C., Yans, J. \& Barbarand, J. 2008. Appui scientifique à la cartographie du régolithe (Grande Terre de Nouvelle-Calédonie) - Rapport intermédiaire, phase 1 (2007-2008). BRGM Report, BRGM/RP-56650-FR, 1-94.

Quesnel, F., Ricordel-Prognon, C., Folcher, N., Sevin, B. \& Mengin, M. 2015. Pétrographie et datation par paléomagnétisme des latérites et sédiments du Sud de la Grande-Terre (Nouvelle-Calédonie) Rapport intermédiaire, phase 5. BRGM Report, BRGM/RP-64902-FR.

Quesnel, F., Ricordel-Prognon, C., Sevin, B., Alizert, L. \& Maurizot, P. 2013b. Pétrographie et datation par paléomagnétisme des latérites et sédiments du Sud de la Grande-Terre (Nouvelle-Calédonie) Rapport intermédiaire, phase 4. BRGM Report, BRGM/RP- 62974-FR.

Quesnel, F., Ricordel-Prognon, C., Sevin, B., Lesimple, S. \& Maurizot, P. 2011. Appui scientifique à la cartographie du régolithe (Grande Terre de Nouvelle-Calédonie) - Rapport intermédiaire, phase 2 (2008-2010). BRGM Report, BRGM/RP- 59561-FR, 1-40.

Quilty, P.G. 1993. Tasmantid and Lord Howe seamounts: biostratigraphy and palaeoceanographic significance. Alcheringa, 17, 27-53.

Regnier, M. 1988. Lateral variation of upper mantle structure beneath New Caledonia dtermined from P-wave receiver function: evidence for a fossil subduction zone. Geophysical Journal, 95, 561577.

Régnier, M., Van de Beuque, S., Baldassari, C. \& Tribot Laspiere, G. 1999. La sismicité du Sud de la Nouvelle-Calédonie: implications structurales. Comptes Rendus de I'Académie des Sciences - Series IIA - Earth and Planetary Science, 329, 143-148, doi: 10.1016/S1251-8050(99)80216-X. 
Richer de Forges, B., Chevillon, C., Okuno, J. \& Castro, P. 1997. Les fonds meubles des lagons de Nouvelle Calédonie (sédimentologie, benthos). Paris (FRA) : ORSTOM, Institut français de recherche scientifique pour le développement en coopération; volume III / Bertrand , coordonateur, 1-139.

Richer de Forges, B., Grandperrin, R. \& Laboute, P. 1987. La campagne Chalcal II sur les guyots de la ride Norfolk (NO" Coriolis" 26 octobre-1er novembre 1986).

Richer de Forges, B., Laboute, P. \& Menou, J.L. 1986. La campagne MUSORSTOM V aux iles Chesterfield; NO" Coriolis"(5-24 octobre 1986). Rapports scientifiques et techniques, 41, 1-31.

Ricordel-Prognon, C., Quesnel, F., Sevin, Alizert, L. \& Maurizot, P. 2011. Appui scientifique à la cartographie du régolithe (Grande Terre de Nouvelle-Calédonie) - Rapport intermédiaire, phase 3. BRGM Report, BRGM/RP-60159-FR.

Ricordel-Prognon, C., Sevin, B., Quesnel, F., Maurizot, P., Alizert, L. \& Cluzel, D. 2013. Intérêt des études pétrographiques pour les datations par paléomagnétisme: exemple des cuirasses latéritiques de Nouvelle Calédonie. 14 ème congrès français de sédimentologie.

Riedl, H. \& Papadopoulos-Vrynioti, K. 2001. Comparative investigations on Karst generations mainly in the Aegean Archipelago. Mict. naturwiss. Ver. Steiermark, 131, 23-39.

Rigolot, P. 1988. Prolongement méridional des grandes structures géologiques de NouvelleCalédonie et découvertes de monts sous-marins interprétés comme un jalon dans un nouvel alignement de Hot-Spot. Comptes Rendus de l'Académie des Sciences. Série 2: Mécanique... 307, 965972.

Rigolot, P. 1989. Evolution morphologique et structurale de la marge occidentale de la ride de Nouvelle-Calédonie (SW Pacifique). Bulletin des Centres de Recherches Exploration-Production Elf Aquitaine, 319-344.

Rigolot, P. \& Pelletier, B. 1988. Tectonique compressive recente le long de la marge Ouest de la Nouvelle-Caledonie: Resultats de la campagne ZOE 400 du N/O Vauban (mars 1987). Comptes Rendus de l'Académie des Sciences, série D, Paris, Série 2, 307, 179-184.

Ritter, M.E. 2006. The Physical Environment: an Introduction to Physical Geography

Rouet, I. 2009. Caractérisation et éléments de quantification d'aléas naturels dans les massifs ultrabasiques de Nouvelle-Calédonie. Ph D. memoir. Université de Nouvelle-Calédonie, Nouméa, 1214.

Rouillard, P., Collot, J., Sutherland, R., Bache, F., Patriat, M., Etienne, S. \& Maurizot, P. 2017. Seismic stratigraphy and palaeogeographic evolution of Fairway Basin, Northern Zealandia, Southwest 
Pacific: from Cretaceous Gondwana breakup to Cenozoic Tonga-Kermadec subduction. Basin Research, 29, 189-212.

Routhier, P. 1953. Etude géologique du versant occidental de la Nouvelle-Calédonie entre le col de Boghen et la pointe d'Arama. Mémoire de la Société Géologique de France, XXXII 1-3 1-271.

Schmidt, M.W. 1992. Amphibole composition in tonalite as a function of pressure: an experimental calibration of the Al-in-hornblende barometer. Contributions to Mineralogy and Petrology, 110, 304310.

Scott, K.M. \& Pain, C.F. 2009. Regolith science. CSIRO Publishing-Springer, Australia, 2009. eds: Keith M. Scott, Colin F. Pain.

Seedorff, E., Dilles, J., Proffett, J., Einaudi, M., Zurcher, L., Stavast, W., Johnson, D. \& Barton, M. 2005. Porphyry deposits: Characteristics and origin of hypogene features. Economic Geology 100th anniversary volume, 29, 251-298.

Seton, M., Müller, R., Zahirovic, S., Gaina, C., Torsvik, T., Shephard, G., Talsma, A., Gurnis, M., et al. 2012. Global continental and ocean basin reconstructions since 200 Ma. Earth-Science Reviews, 113, 212-270.

Seton, M., Williams, S., Mortimer, N., Meffre, S. \& Micklethwaite, S. 2016. Voyage report for SS2012V06 Eastern Coral Sea Tectonics (ECOSAT), R/V Southern Surveyor, October-November 2012. GNS Science Report 2016/49. GNS Science. Lower Hutt, New Zealand.

Sevin, B. 2014. Cartographie du régolithe sur massifs ultrabasiques. Localisation dans l'espace et le temps des gisements nickélifères. Ph.D. Thesis, Univesity of New Caledonia, Noumea.

Sevin, B., Cluzel, D., Maurizot, P., Ricordel-Prognon, C., Chaproniere, G., Folcher, N. \& Quesnel, F. 2014. A drastic lower Miocene regolith evolution triggered by post obduction slab break-off and uplift in New Caledonia. Tectonics, 33, 1787-1801.

Sevin, B., Ricordel-Prognon, C., Quesnel, F., Cluzel, D., Lesimple, S. \& Maurizot, P. 2012a. First palaeomagnetic dating of ferricrete in New Caledonia: new insight on the morphogenesis and palaeoweathering of 'Grande Terre'. Terra Nova, 24, 77-85, doi: 10.1111/j.1365-3121.2011.01041.x.

Sevin, B., Ricordel-Prognon, C., Quesnel, F., Cluzel, D. \& Maurizot, P. 2010. Palaeomagnetic dating of ferricretes in New Caledonia. Preliminary results. EGU General Assembly Conference Abstracts, 12, 4052.

Sevin, B., Ricordel-Prognon, C., Quesnel, F., Cluzel, D. \& Maurizot, P. 2012b. Post-obduction dismantling of the early regolith and related conglomerates in the Kopeto-Boulinda-Nepoui area (New Caledonia): a possible Lower Miocene uplift and palaeolandscape. 34th International Geological Congress, 1000. 
Stevenson, J., Gillespie, R., Hope, G., Jacobsen, G., Fallon, F. \& Levchenko, V. 2010. The archaic and puzzling record of Lake Xere Wapo, New Caledonia. Terra Australis. Chapter 21. Altered ecologies: Fire, climate, and Human influence on terrestrial landscapes, 32, 381-393.

Stevenson, J. \& Hope, G. 2005. A comparison of late Quaternary forest changes in New Caledonia and northeastern Australia. Quaternary Research, 64, 372-383.

Sun, S.-S. \& McDonough, W.-S. 1989. Chemical and isotopic systematics of oceanic basalts: implications for mantle composition and processes. Geological Society, London, Special Publications, 42, 313-345.

Sutherland, R., Collot, J., Lafoy, Y., Logan, G.A., Hackney, R., Stagpoole, V., Uruski, C., Hashimoto, T., Higgins, K., Herzer, R.H., Wood, R., Mortimer, N. \& Rollet, N. 2010. Lithosphere delamination with foundering of lower crust and mantle caused permanent subsidence of New Caledonia Trough and transient uplift of Lord Howe Rise during Eocene and Oligocene initiation of Tonga-Kermadec subduction, western Pacific. Tectonics, 29, n/a-n/a, doi: 10.1029/2009tc002476.

Sutherland, R., Viskovic, G.P.D., Bache, F., Stagpoole, V.M., Collot, J., Rouillard, P., Hashimoto, T., Hackney, R., Higgins, K., Rollet, N., Patriat, M. \& Roest, W.R. 2012. Compilation of seismic reflection data from the Tasman Frontier region, southwest Pacific. GNS Science Report 2012/01. New Zealand, GNS Science.

Taylor, G. \& Eggleton, R.A. 2001. Regolith Geology and Geomorphology. Chichester, New York, Weinheim, Brisbane, Singapore, Toronto: John Wiley \& Sons Ltd, 375 pp.

Tercinier, G. 1963. Les sols de la Nouvelle-Calédonie. ORSTOM, Institut Français d'Océanie, 1-51.

Tessarolo, C. 1997. The Pindaï Peninsula limestone resource. Result of the 1996 coring campaign resource evaluation. Goro Nickel internal report, 1-76.

Thinon, I. 2015. Acquisition marine de profils de sismique réflexion Très Haute Résolution dans la baie de Népoui (campagne NEPSIS) - Rapport final. Bureau de Recherches Géologiques et Minières report $B R G M / R P-64697-F R, 1-150$.

Thomas, M.F. 1994. Geomorphology in the tropics: a study of weathering and denudation in low latitudes. John Wiley \& Sons.

Thomassin, B.A. \& Vasseur, P. 1981. The coral reef complexes of the SW coast of New Caledonia ; building and geomorphology. Abstract. Proceedings of the $4 \mathrm{~h}$ international Coral Reef Symposium, Manila, 66.

Till, C.B., Gans, P.B., Spera, F.J.,Macmillan, I., Blair, K.D. 2009. Perils of petrotectonic modeling: a view from southern Sonora, Mexico. Journal of Volcanology and Geothermal Research, 186, 160-168. 
Tournadour, E. Fournier, F. Etienne, S. Collot, J. Patriat, M. Maurizot, P. Sevin, B. Morgans,H.E.G. (submitted), Architecture and facies evolution of mixed carbonate siliciclastic systems: example of the New Caledonian western margin (Népoui Formation, Lower Miocene, New Caledonia). Sedimentology.

Trescases, J.-J. 1975. L'evolution géochimique supergène des roches ultrabasiques en zone tropicale : formation des gisements nickélifères de Nouvelle-Calédonie Paris, France : O.R.S.T.O.M.

Trescases, J.J. 1973. Weathering and geochemical behaviour of the elements of ultramafic rocks in New Caledonia. Bureau of Mineral Resources, Geology and geophysics Bulletin , Canberra, , 141, 149161.

Van De Beuque, S. 1999. Evolution Géologique du domaine péri-Calédonien(Sud-Ouest Pacifique). $\mathrm{PhD}$, Université de Bretagne Occidentale.

Van de Beuque, S., Auzende, J.-M., Lafoy, Y., Bernardel, G., Nercessian, A., Régnier, M., Symonds, P. \& Exon, N. 1998. Transect sismique continu entre l'arc des Nouvelles-Hebrides et la marge orientale de I'Australie: programme FAUST (French Australian Seismic Transect). Comptes Rendus de l'Académie des Sciences-Series IIA-Earth and Planetary Science, 327, 761-768.

Vendé-Leclerc, M., Maurizot, P., LeCozannet, G., Robineau, B. \& Nicolae-Lerma, A. 2016. Lagoon islets as indicators of recent environmental changes in the South Pacific - The New Caledonian example. Continental ShelfResearch, 122, 120-140, doi: 10.1016/j.csr.2016.03.025.

Vermeesch, P. 2006. Tectonic discrimination diagrams revisited. Geochemistry, Geophysics, Geosystems, 7.

Vogt, J. \& Podvin, P. 1983. Carte Géologique à l'échelle du 1 / 50000 et notice explicative: feuille Humboldt-Port-Bouquet. Territoire de Nouvelle-Calédonie - Bureau de Recherches Géologiques et Minières, 1-68.

Waelbroeck, C., Labeyrie, E., Miche, E., Duplessy, J.C., McManusc, J.F., Lambeck, K., Balbon, E. \& Labracherie, M. 2002. Sea-level and deep water temperature changes derived from benthic foraminifera isotopic records. Quaternary Science Reviews, 21, 295-305.

Williams, S., Mortimer, N., Etienne, S., Whittaker, J., Herold, N., O'toole, O., Sauermilch, I., Tobin, J., Yeung, S., Seton, M. \& Collot, J. 2016. Voyage report for IN2016T01 Eastern Coral Sea Tectonics follow up (ECOSAT II), R/V Investigator, June-July 2016, GNS Science Report 2016/50. 56pp. .

Wilson, M. 1989. Igneous Petrogenesis. Unwin Hyman, London.

Wirrmann, D., Sémah, A.-M. \& Chacornac-Rault, M. 2006. Late Holocene palaeoenvironment in northern New Caledonia, southwestern Pacific, from a multiproxy analysis of lake sediments. Quaternary Research, 66, 213-232. 
Wirrmann, D., Sémah, A.-M., Debenay, J.-P. \& Chacornac-Rault, M. 2011. Mid- to late Holocene environmental and climatic changes in New Caledonia, southwest tropical Pacific, inferred from the littoral plain Gouaro-Déva. Quaternary Research, 76, 229-242, doi: 10.1016/j.yqres.2011.04.007.

Wirrmann, D., Sémah, A.M. \& Chacornac-Rault, M. 2007. Littoral palaeoenvironmental changes throughout the last 3500 years in central New Caledonia inferred from Fournier swamp. Proceedings XVII INQUA Congress, Cairns Australie, http://www.icms.com.au/inqua2007/abstract/1070.htm.

Wirthmann, A. 1965. Die Reliefentwicklung von Neukaledonien. Deutscher Geographentag. Tagungsbericht und Wiss. Abh., 8, 323-335.

Wirthmann, A. 1970. Zur geomorphologie der peridotite auf Neu Kadedonien. Tübing. Geogr. Stud., 34, 191-201.

Wood, D.A., 1980. The application of a Th-Hf-Ta diagram to problems of tectonomagmatic classification and to establishing the nature of crustal contamination of basaltic lavas of the British Tertiary Volcanic Province. Earth and Planetary Science Letters. 50 (1), 11-30, doi: 10.1016/0012$821 \times(80) 90116-8$.

Wright, V.P. 2008. Calcrete. In: McLaren, e.D.J.N.a.S.J. (ed.) In Geochemical Sediments and Landscapes.

Yamano, H., Cabioch, G., Chevillon, C. \& Join, J.L. 2014. Late Holocene sea-level change and reefisland evolution in New Caledonia. Geomorphology, doi: 10.1016/j.geomorph.2014.03.002.

Zachos, J., Pagani, M., Sloan, L., Thomas, E. \& Billups, K. 2001. Trends, rhythms, and aberrations in global climate $65 \mathrm{Ma}$ to present. Science, 292, 686-693.

Zindler, A. \& Hart, S.R. 1986. Chemical geodynamics. Annual Review of Earth and Planetary Sciences, 14, 493-571. 


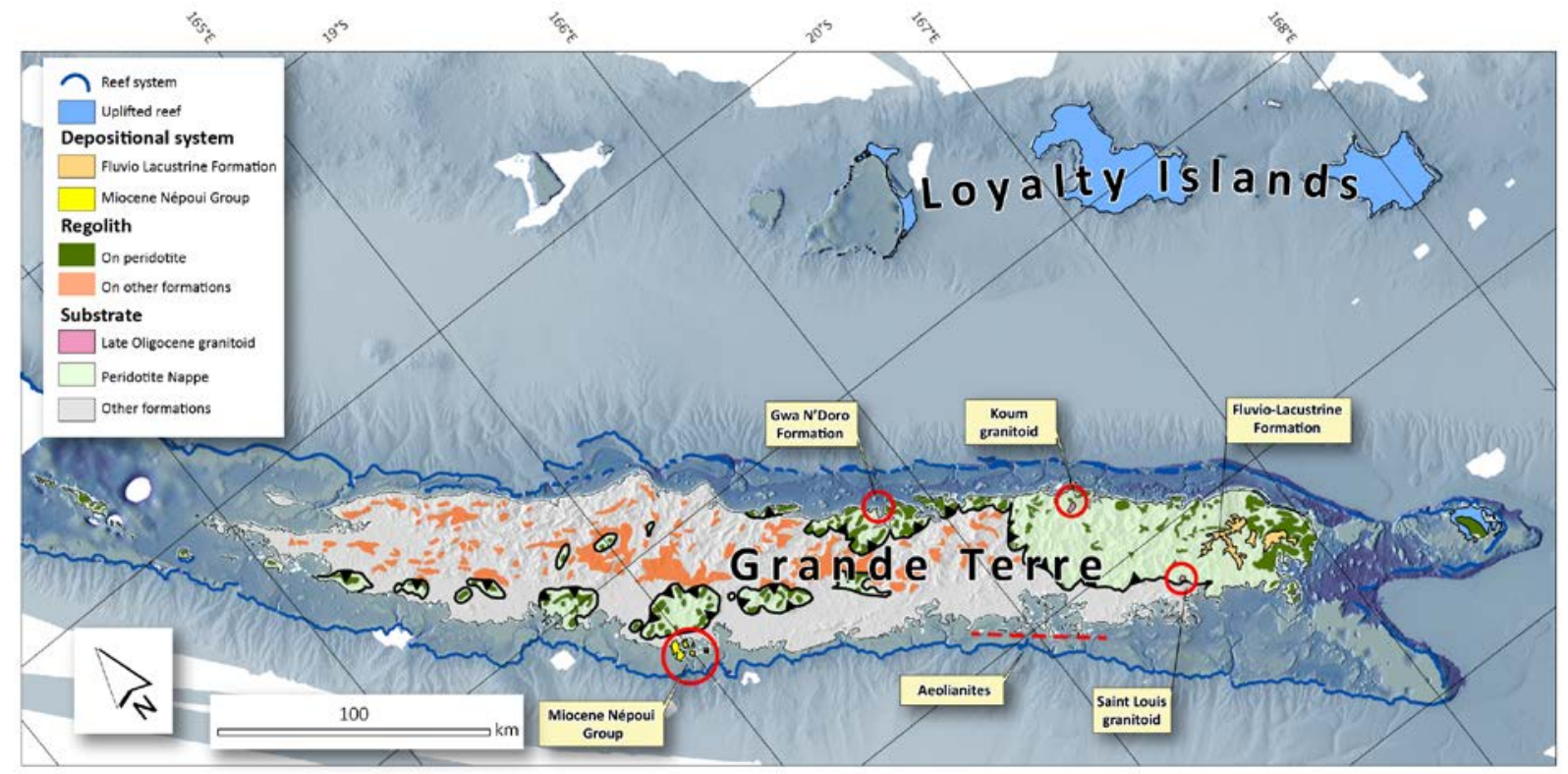

Fig. 1 Simplified geological map of New Caledonia emphasising the distribution of Oligocene-Recent rocks. 


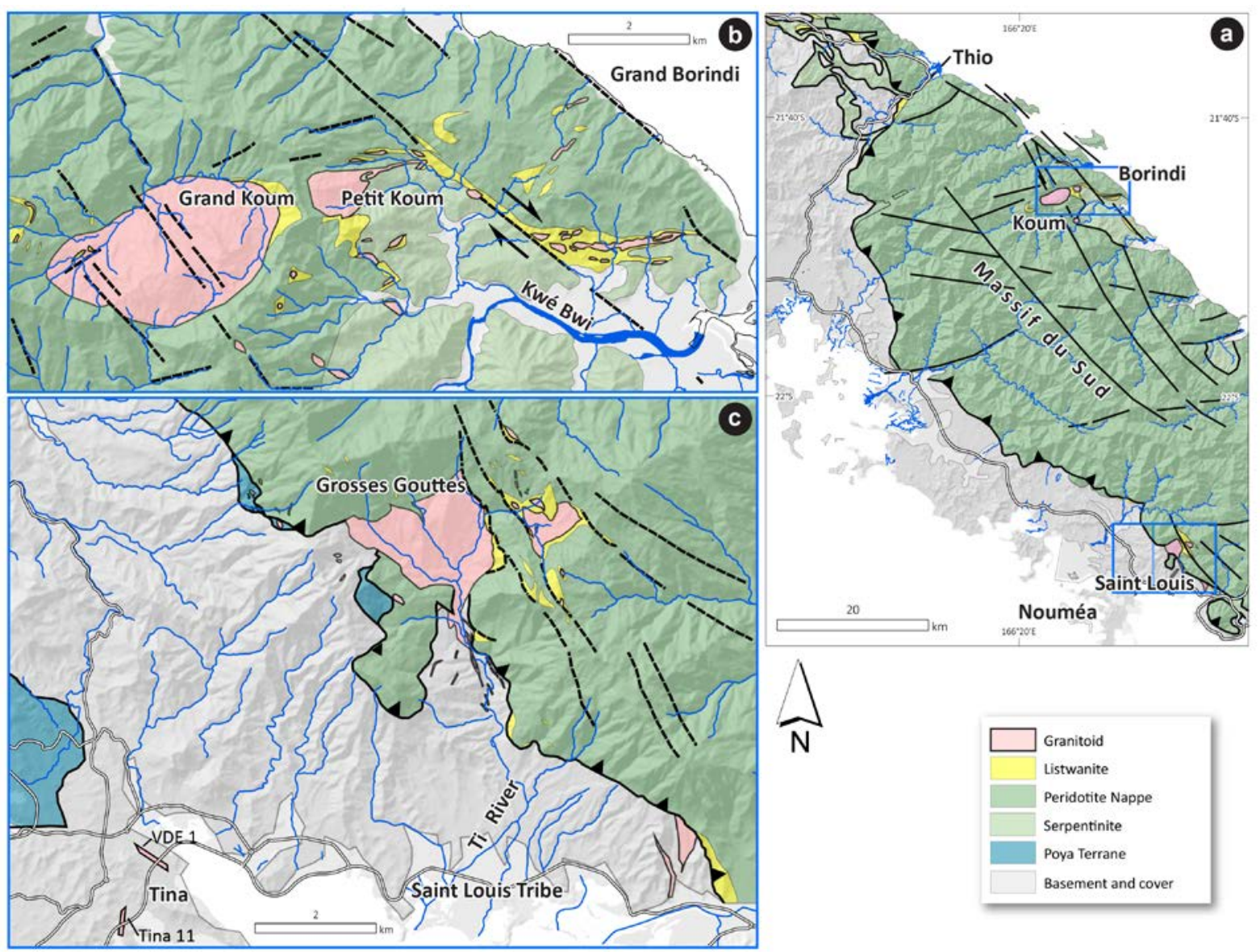

Fig. 2 Geological maps of post-obduction granitoid intrusions in the Peridotite Nappe. a) General map of the Massif du Sud. b) Koum pluton. c) Saint Louis pluton showing the crosscuting relationship of the granodiorite with the cover and the Peridotite Nappe. 


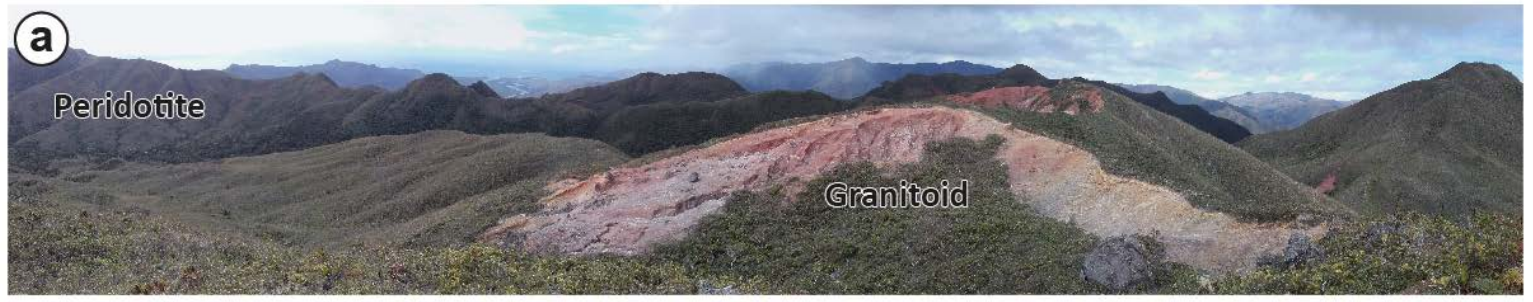

(C)

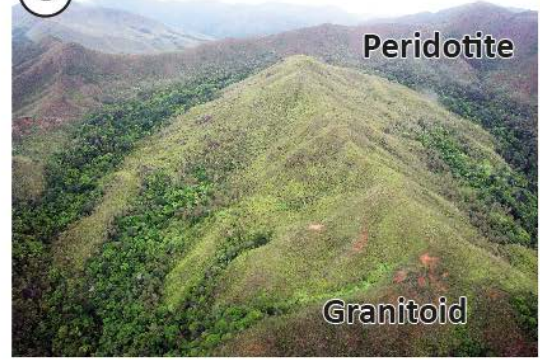

(b)

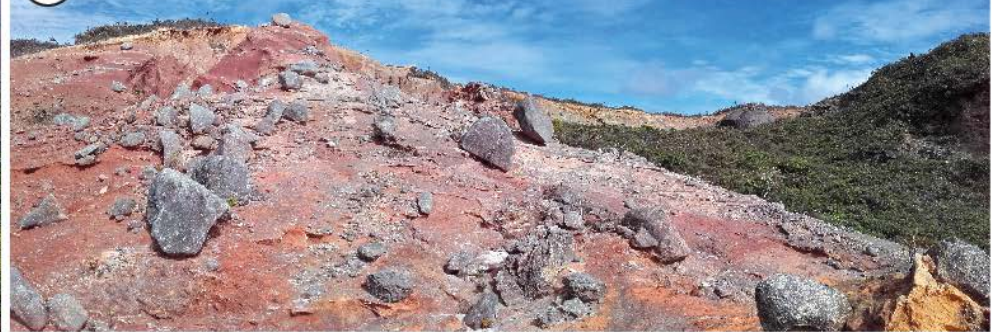

Fig. 3 a) View from the west of Grand Koum granitoid; b) Weathered Grand Koum granitoid; c) Aerial view from the east of Petit Koum granitoid. 

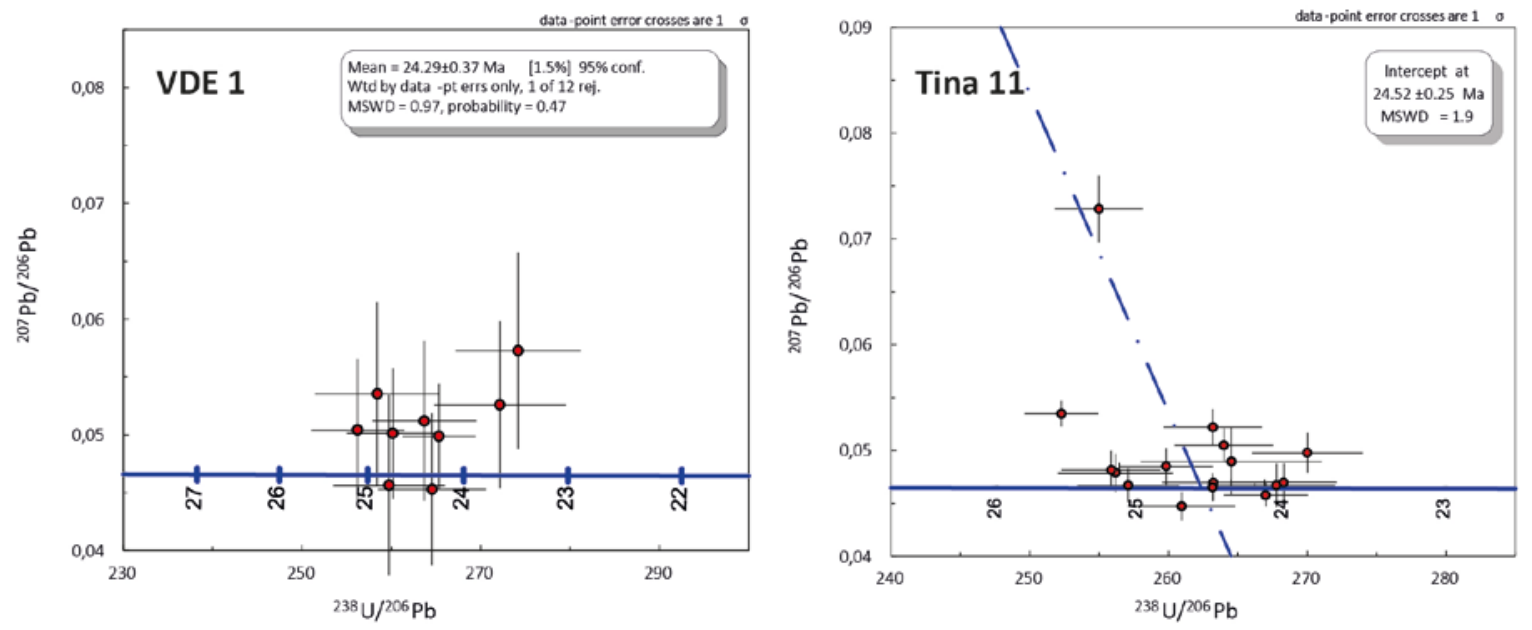

Fig. 4 Reverse concordia diagrams showing U-Pb ages of zircons analyzed from two granitoid dykes of Saint Louis suite, which crosscut autochthonous basement rocks; see location on Fig. 1.

68 

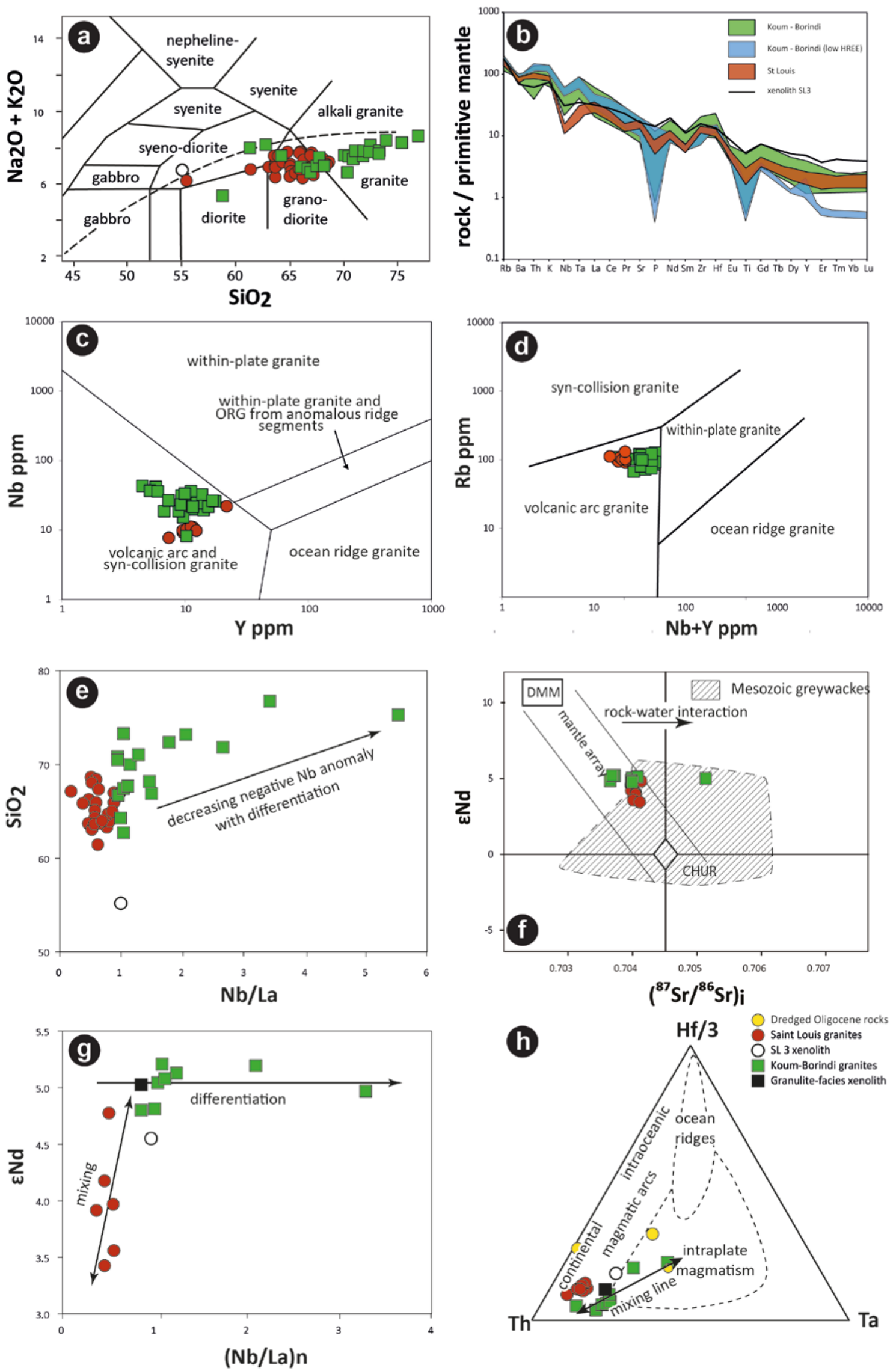
Fig. 5 a) Total alkali-silica diagram after Le Bas et al. (1986) adapted by Wilson (1989) to show the classification of Saint Louis and Koum-Borindi granitoids in the fields of granodiorite and sub alkali granite; b) Expanded rare-earth and trace element spider diagram for Oligocene granitoids (data from Cluzel et al, 2005; primitive mantle normalization after Sun and McDonough, 1989); c) and d) $\mathrm{Nb}$ vs. $\mathrm{Y}$ and $\mathrm{Rb}$ vs. $\mathrm{Nb}+\mathrm{Y}$ discriminant diagrams of Pearce et al. (1984), to show the location of Oligocene granitoids in the field of volcanic-arc granites and a slightly higher $\mathrm{Nb}$ content in KoumBorindi rocks (green squares), which makes them closer to within-plate granites; e) Plot of ( $\mathrm{Nb} / \mathrm{La}) \mathrm{n}$ vs. $\mathrm{SiO} 2$ indicating a restricted correlation of decreasing $\mathrm{Nb}$ negative anomaly and differentiation, except for the more silica-rich granitoids (SiO2 > 72\%); f) (87Sr/86Sr)i vs. $\varepsilon N d$ plot of Saint Louis and Koum-Borindi granitoids corrected for in situ decay at $27 \mathrm{Ma}$ and $24 \mathrm{Ma}$ respectively. (DMM:

Depleted MORB Mantle; CHUR: Chondritic Uniform reservoir after (Zindler \& Hart 1986); g) Variation of ( $\mathrm{Nb} / \mathrm{La}) \mathrm{n}$ ( $\mathrm{Nb}$ negative anomaly) vs. $\varepsilon \mathrm{Nd}$ to suggest evidence for source mixing ( $\mathrm{Nb}$ and La normalized to the Primitive Mantle values as on Figure 5c ). h) Hf-Th-Ta diagram after Wood (1980) modified by Vermeesch (2006) to show the narrow field of compositions of Saint Louis volcanic-arc granitoids; and in contrast, the mixing line delineated by compositions of Koum-Borindi granitoids, which indicate some influence of an intraplate component. Oligocene lavas dredged on the Norfolk Ridge (Mortimer et al. 2014) are plotted for comparison. 


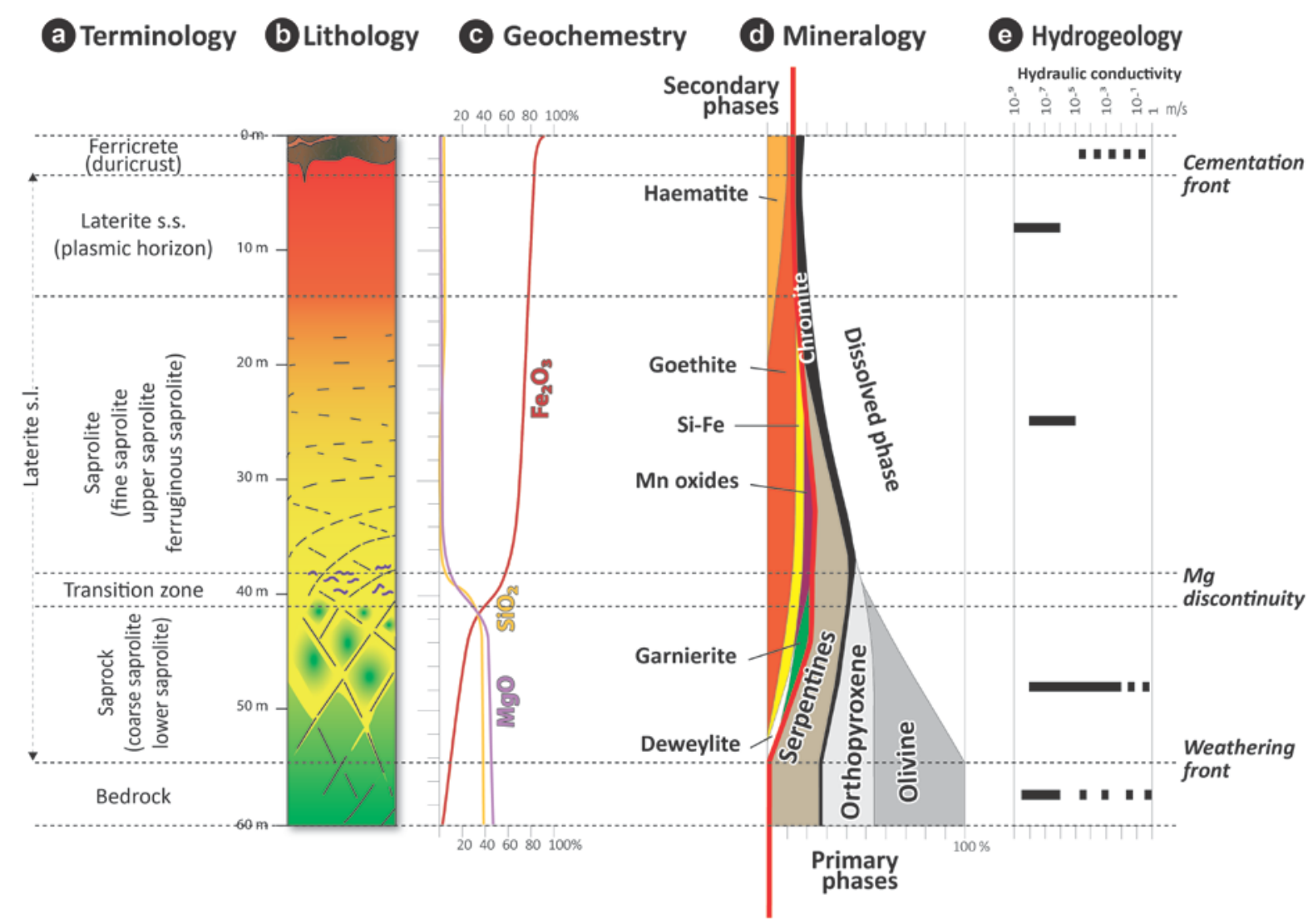

Fig. 6 Some features of weathering profiles developed on ultramafic protolith. a) Common (and less used) terms used for the different levels of the weathering profile. b) Structure and thickness of the weathering profile. c) Smoothed variations of major and minor elements (compiled after Bailly et al. 2014; Latham 1986; Sevin 2014; Trescases 1975; Fritsch et al., 2014; Scott \& Pain 2009; Taylor \& Eggleton 2001). d) Typical proportion of mineral phases in a composite weathering profile (modified after Trescases 1973). e) Hydraulic conductivity values after Jeanpert 2016 and Join 2005). 

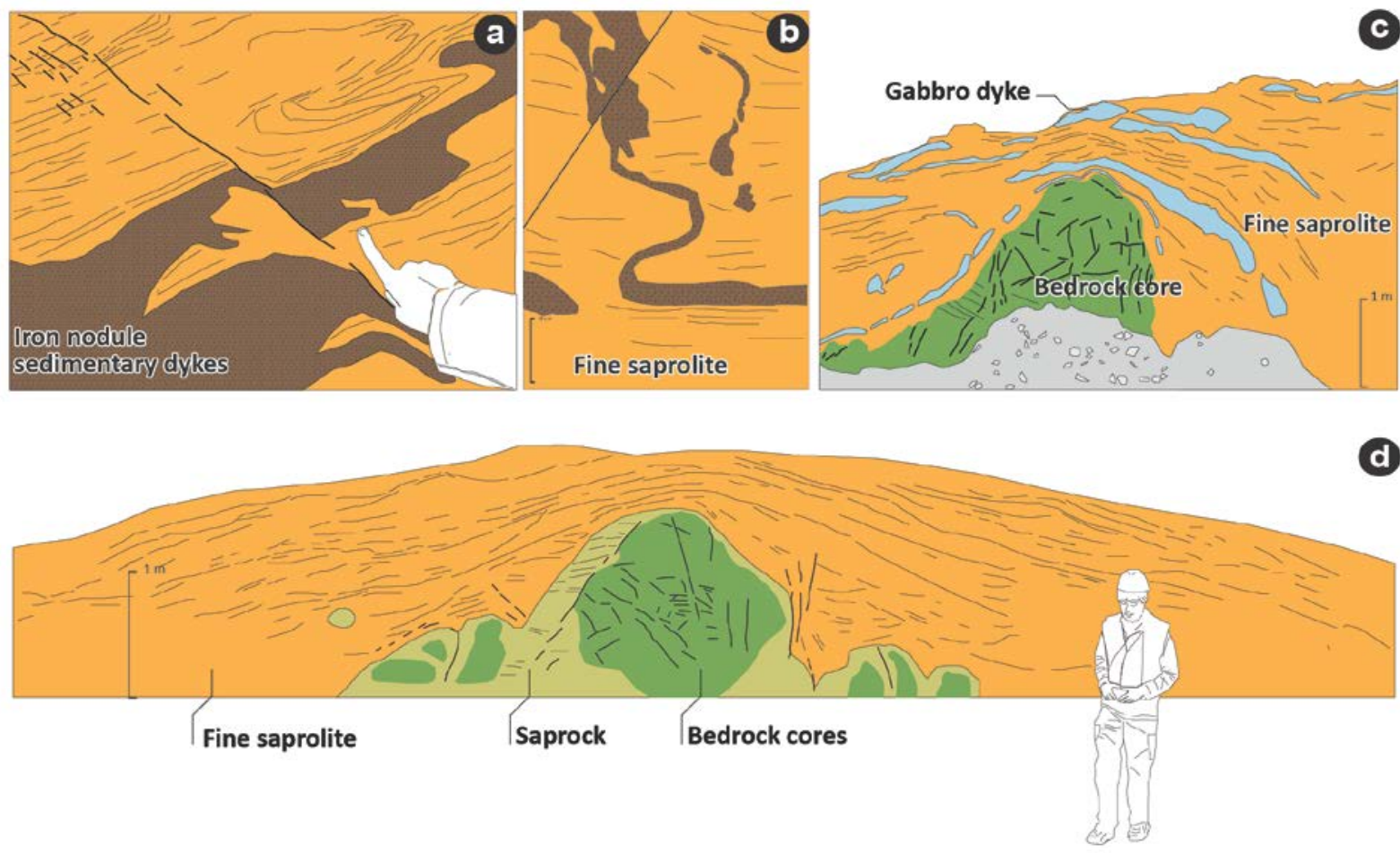

Fig. 7 Sketches of deformation in saprolites: a) Folded and faulted iron nodules and sedimentary dyke in saprolite (Nakety); b) Ptygmatic folds and faults of an iron nodule sedimentary dyke in saprolite (Poro); c) downwarped weathered gabbro dykes in a saprolite matrix, draped over a bedrock core (Bogota); d) saprolite recumbent draped over bedrock cores (Goro mine, mining face, 2011). 


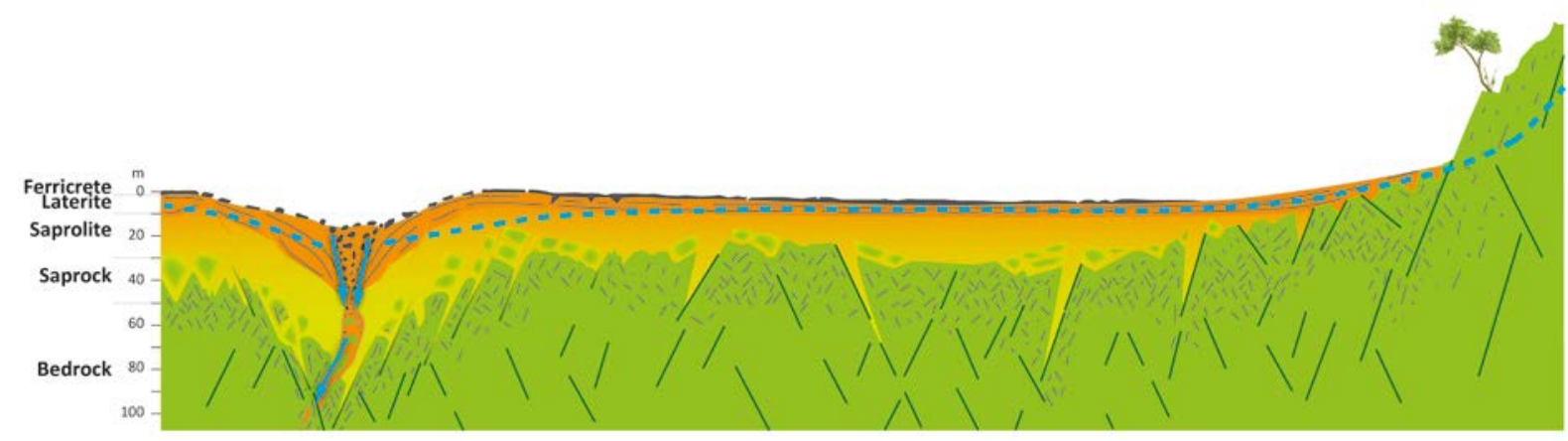

Fig. 8 Schematic representation of part of a weathering cell with a sinkhole to the left and a residual ridge to the right. Note the lateral thinning-out of the ferricrete towards the ridge. Dashed blue lines indicate the average water table level. 


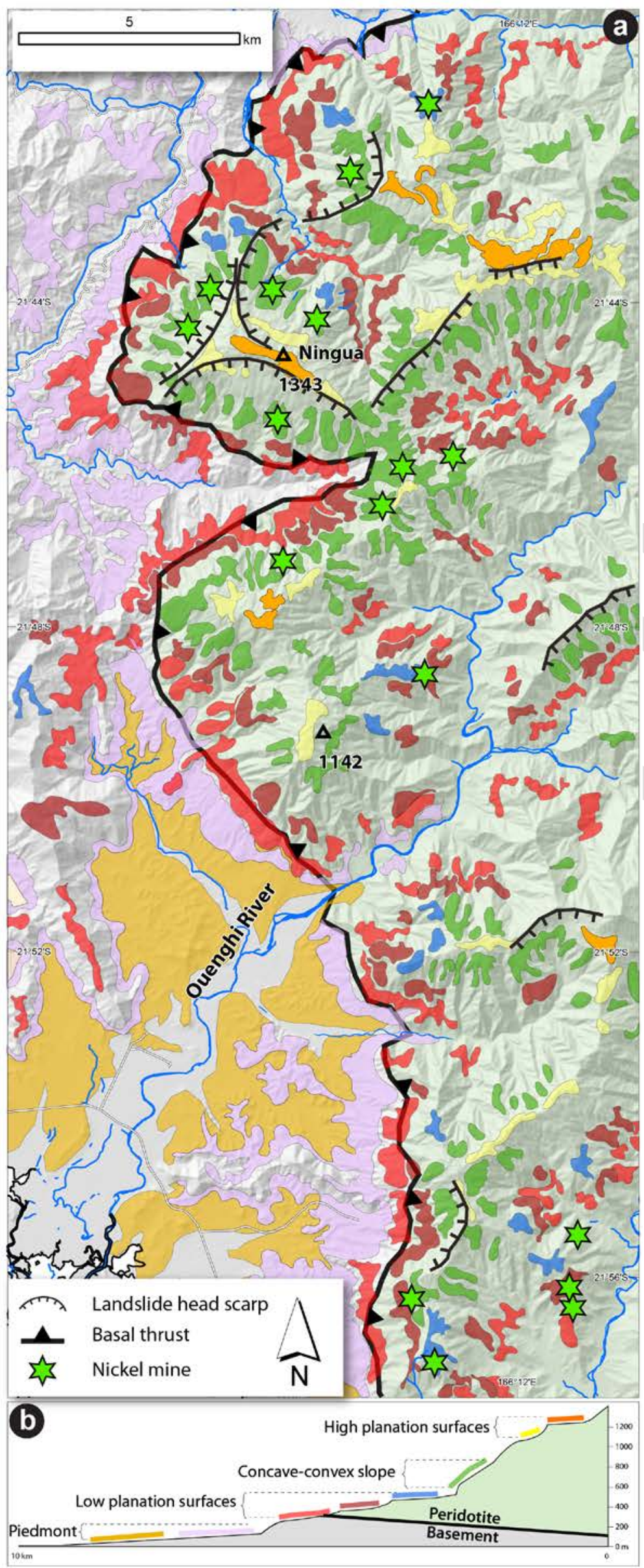


Fig. 9 a) Map of stepped weathering surfaces in the northeastern part of Massif du Sud. b) Schematic EW cross section. Modified from Chevillotte et al. 2006. Same color codes on a) and b). 

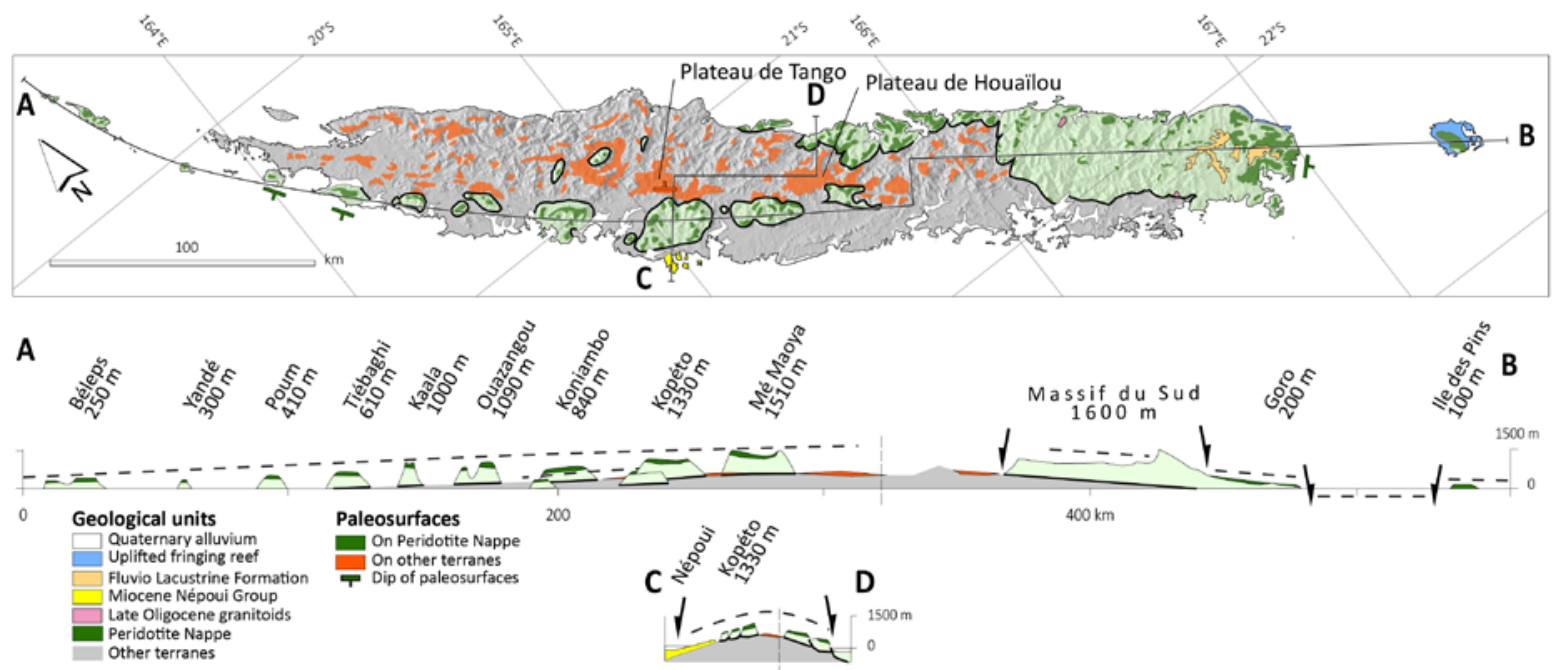

Fig. 10 Simplified geological map and cross sections showing the twin longitudinal and transverse upwarping of Grande Terre (modified from Sevin et al. 2012). 


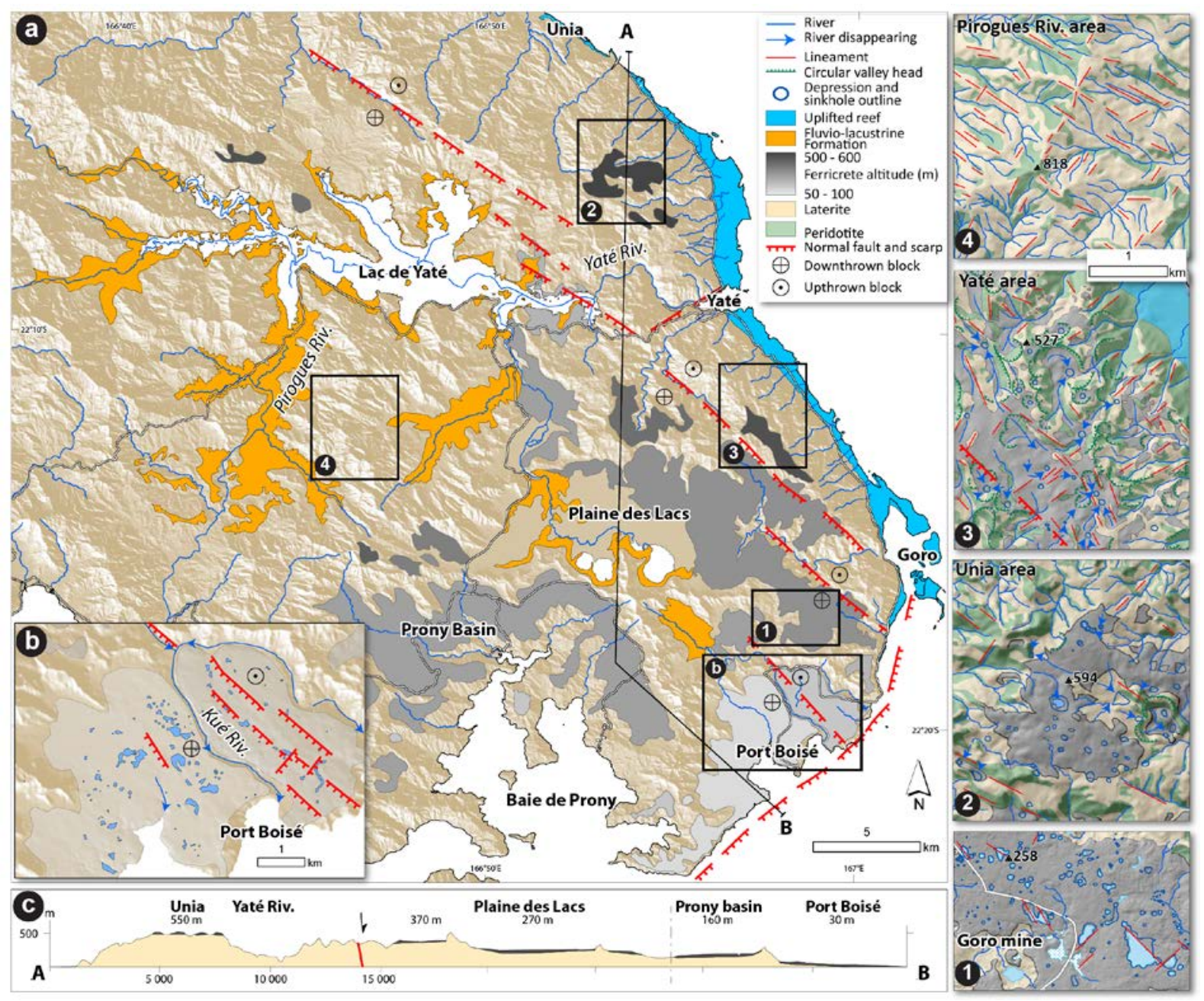

Fig. 11 a) Simplified geological map of the southern part of Massif du Sud. b) Detail of the Port Boisé weathering cell. This basin is crosscut by a set of steep faults that uplifted its NE part. To the SW a gradual contact with the surrounding peridotite crest is preserved. To the $\mathrm{NE}$, the same contact is incised by rivers, in response to uplift. c) Cross section showing the general lowering of the stepped ferricrete surfaces from north to south. Low altitude basins of the south are inverted to plateaux in the north. Note that the Port Boisé ferricrete surface plunges under sea level. 1,2,3, and 4) Examples of four stages of landforming (drawn at the same scale) from bedrock through basin and inverted plateau, to dissected mountains. 


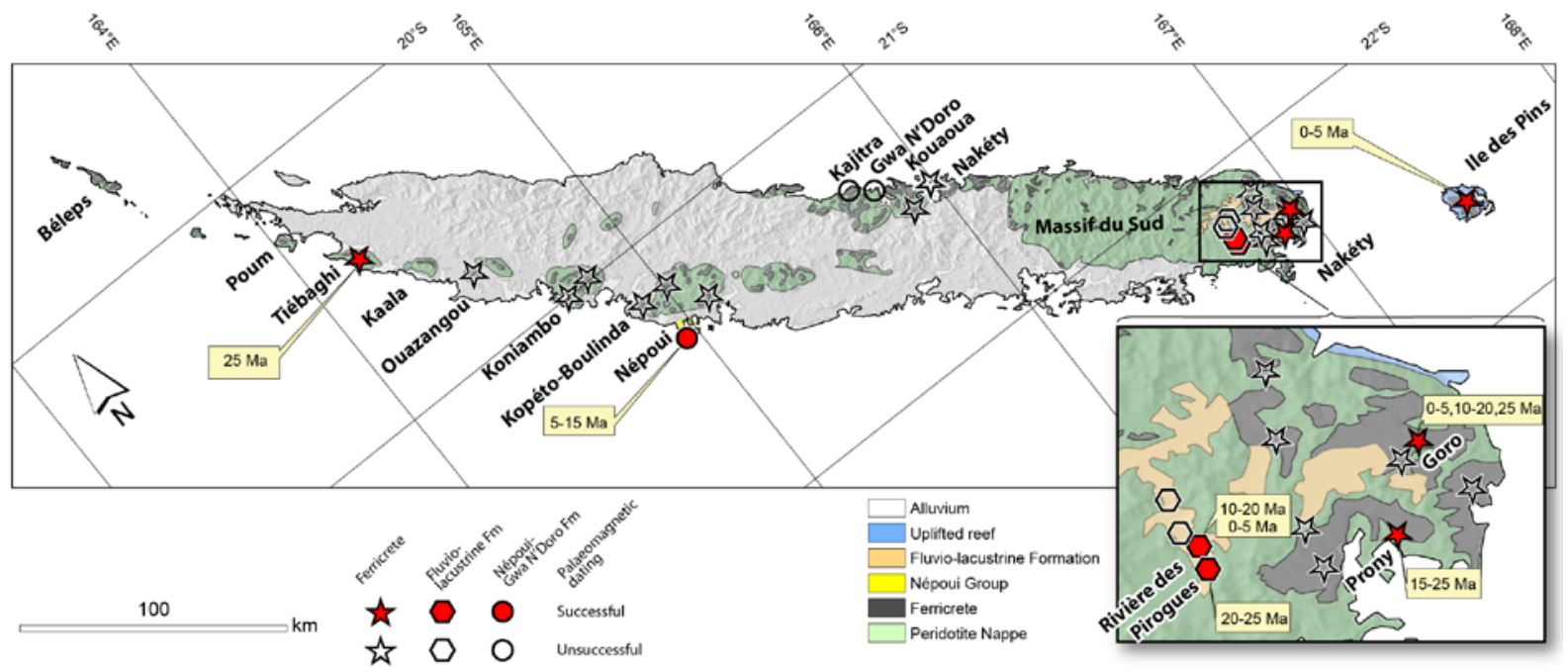

Fig. 12 Palaeomagnetic sample sites and results (after Sevin 2014). Numbers in boxes are interpreted ages of the magnetic vectors at each site. 


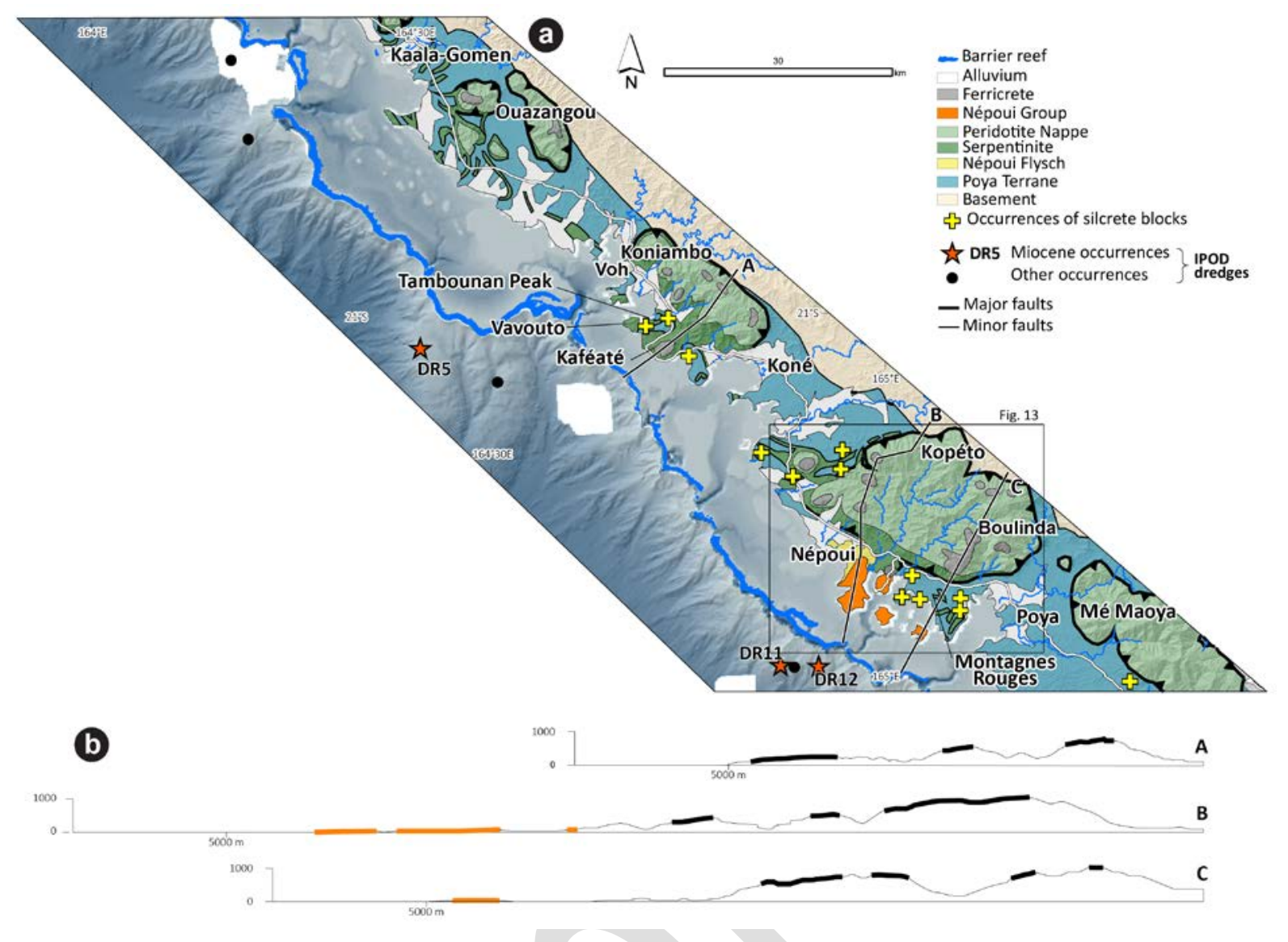

Fig. 13 a) Geological map of the SW coast between Népoui and Kaala-Gomen showing Miocene rock occurrences. b) Topographic profiles (no vertical exaggeration) showing main regolith surfaces on Peridotite Nappe (thick black lines) and Miocene formations (orange). 


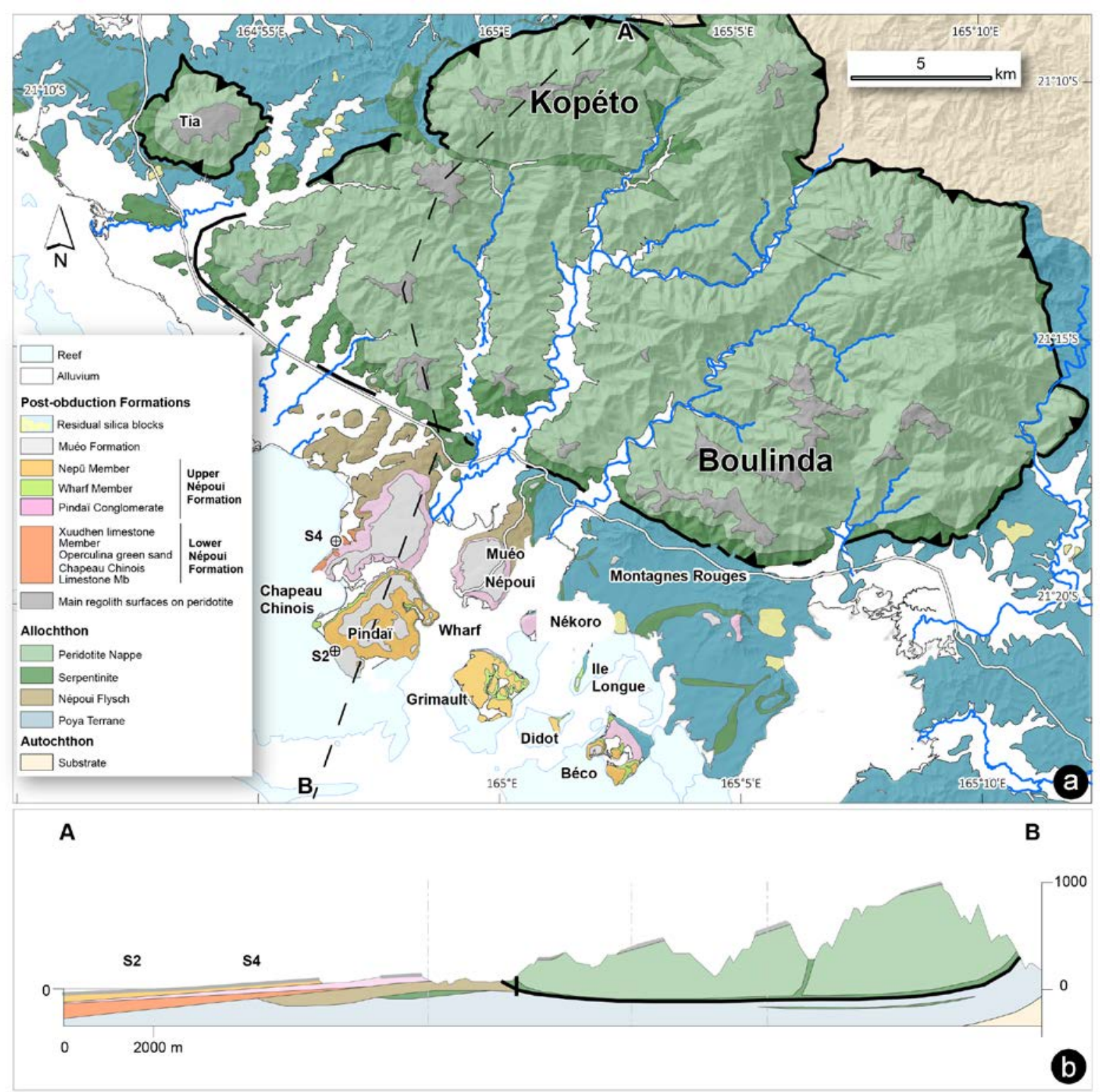

Fig. 14 a) Geological map of the Népoui area. b) Cross section from Kopéto to Pindaï Peninsula. 

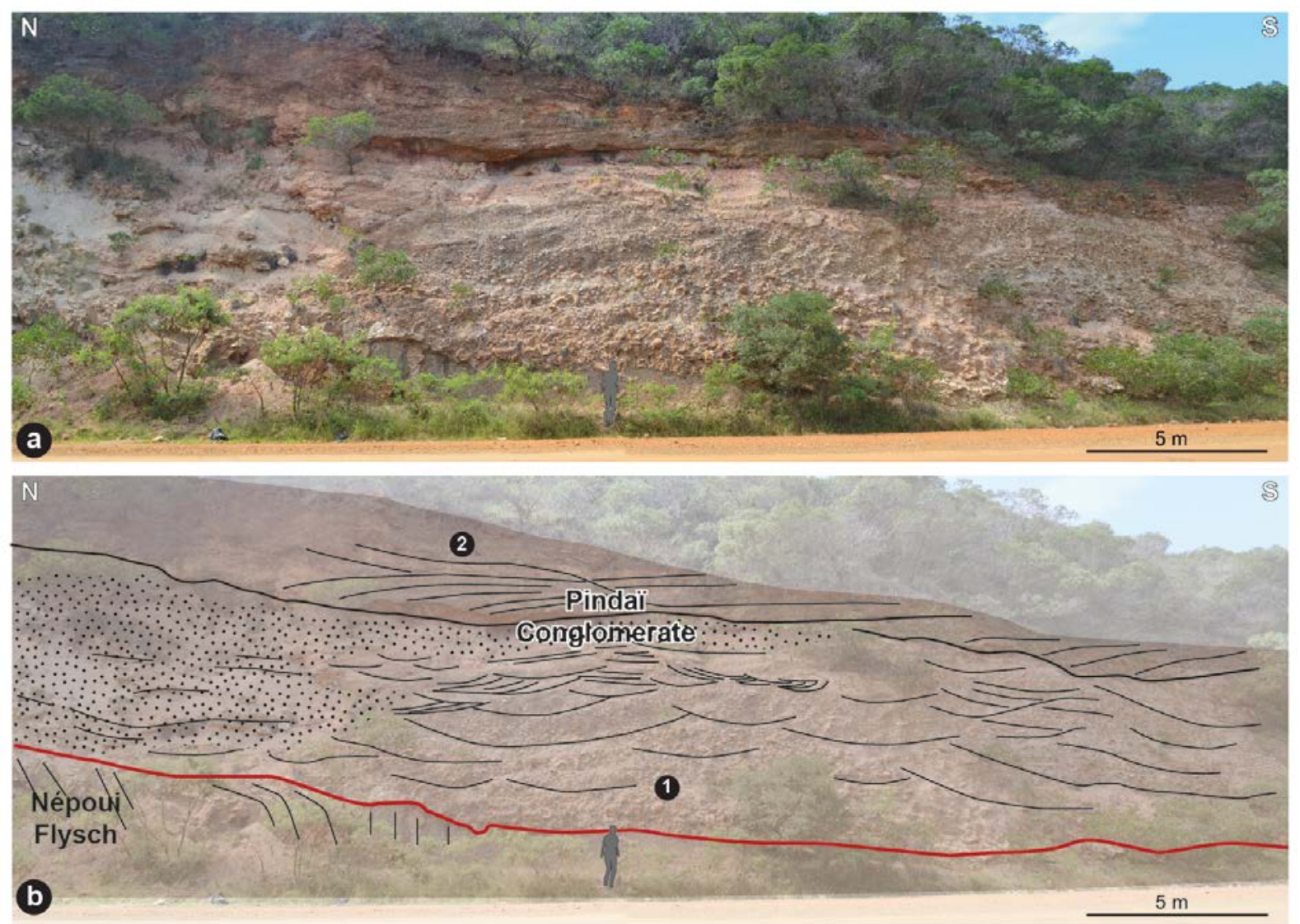

Fig. 15 a) The unconformity of the Pindaï Conglomerate over the Eocene Népoui Flysch (road cut on the east coast of the Muéo Peninsula. b) Line drawing interpretation showing lower conglomerate with trough cross bedding and imbricated pebbles (labelled 1), fining upward into sandstone, overlain by more planar-bedded conglomerate (labelled 2 ). 


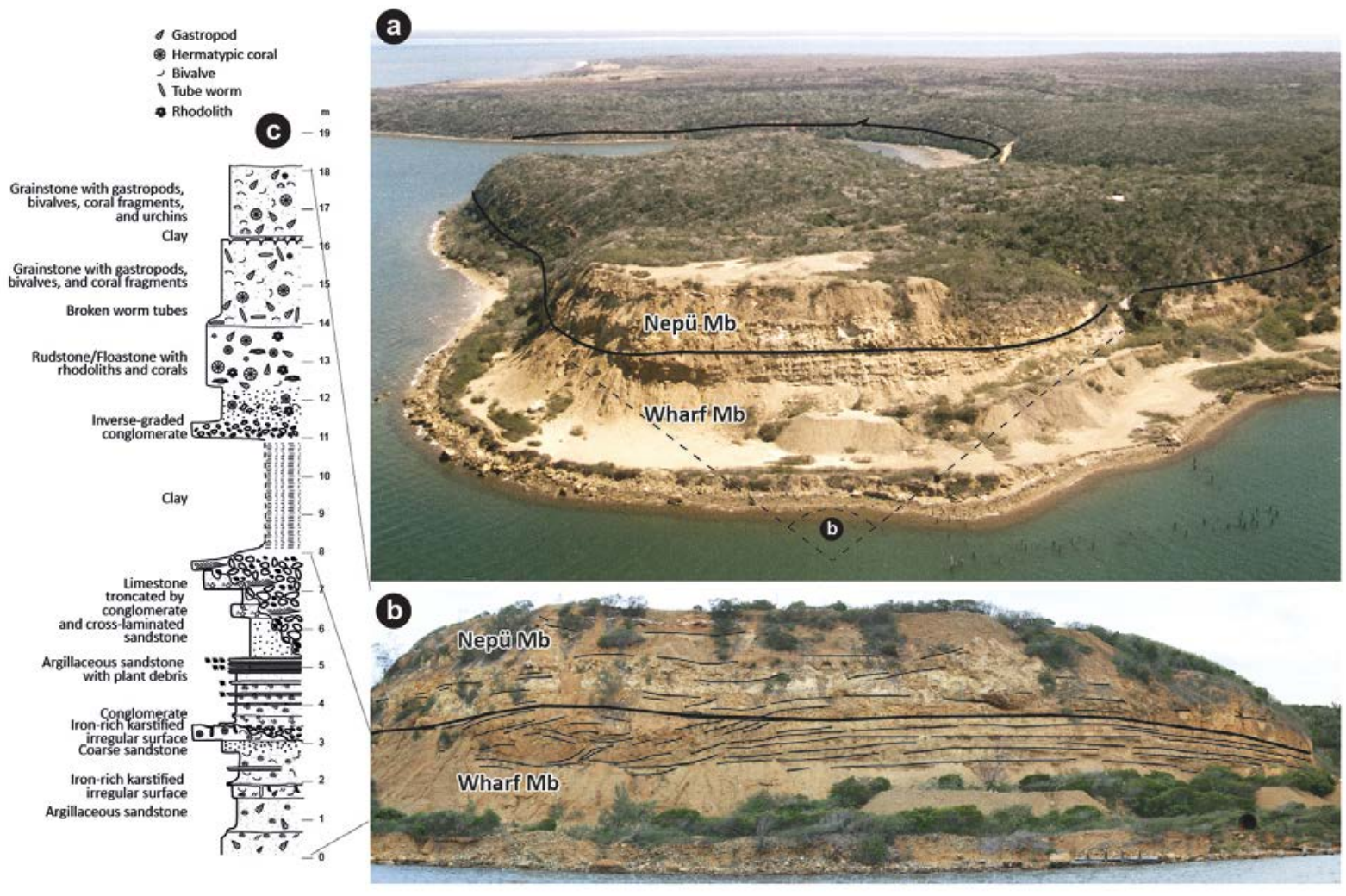

Fig. 16 Upper Népoui Formation outcrops on Pindaï Peninsula. a) Aerial view from the east of the old Pindaï wharf locality. b) Close-up view from the sea of the reference section near the wharf. 


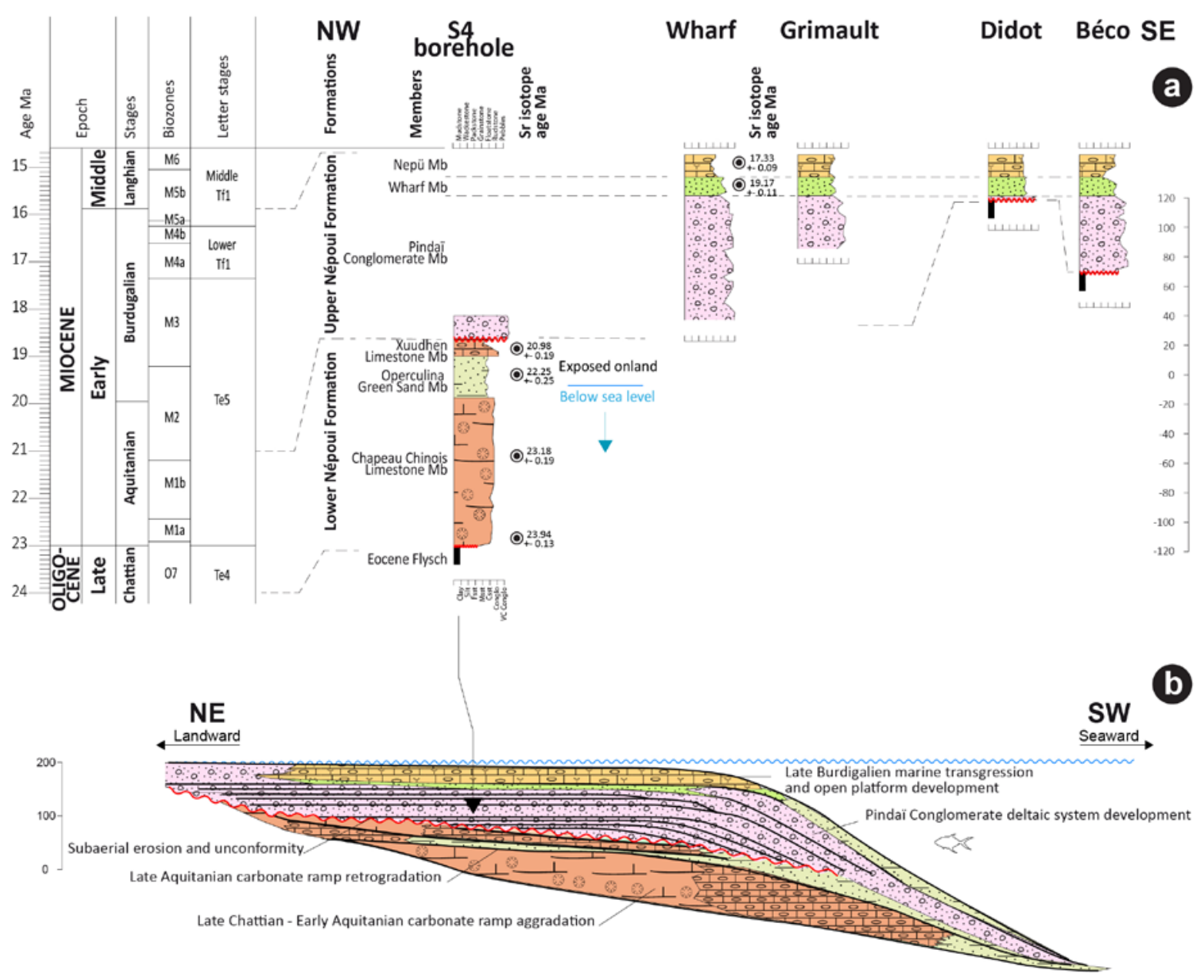

Fig. 17 The Miocene Népoui Group: a) Correlated stratigraphic sections. b) Schematic model of stratigraphic architecture in the Late Burdigalian (modified after Maurizot et al 2016). 

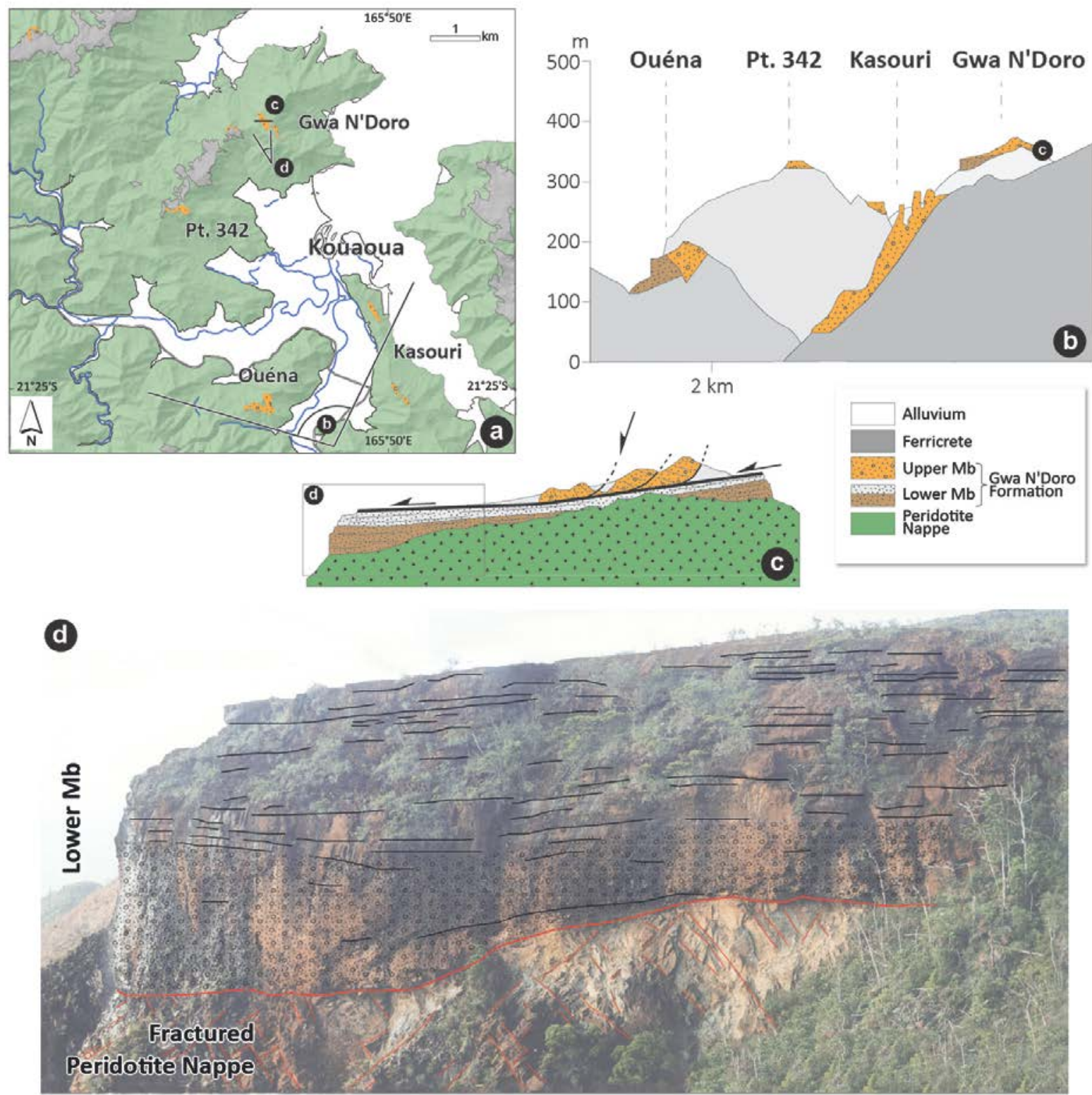

Fig. 18 Gwa N'Doro Formation. a) Simplified geological map of Kouaoua area. b) Sketch of the relative projected positions of the different outcrop localities, viewed from the SE (modified from Chardon et al. 2006). c) Cross section of Gwa N'Doro Formation at the type locality (modified after Chardon et al. 2006). d) Line drawing on an image of the lower member. 


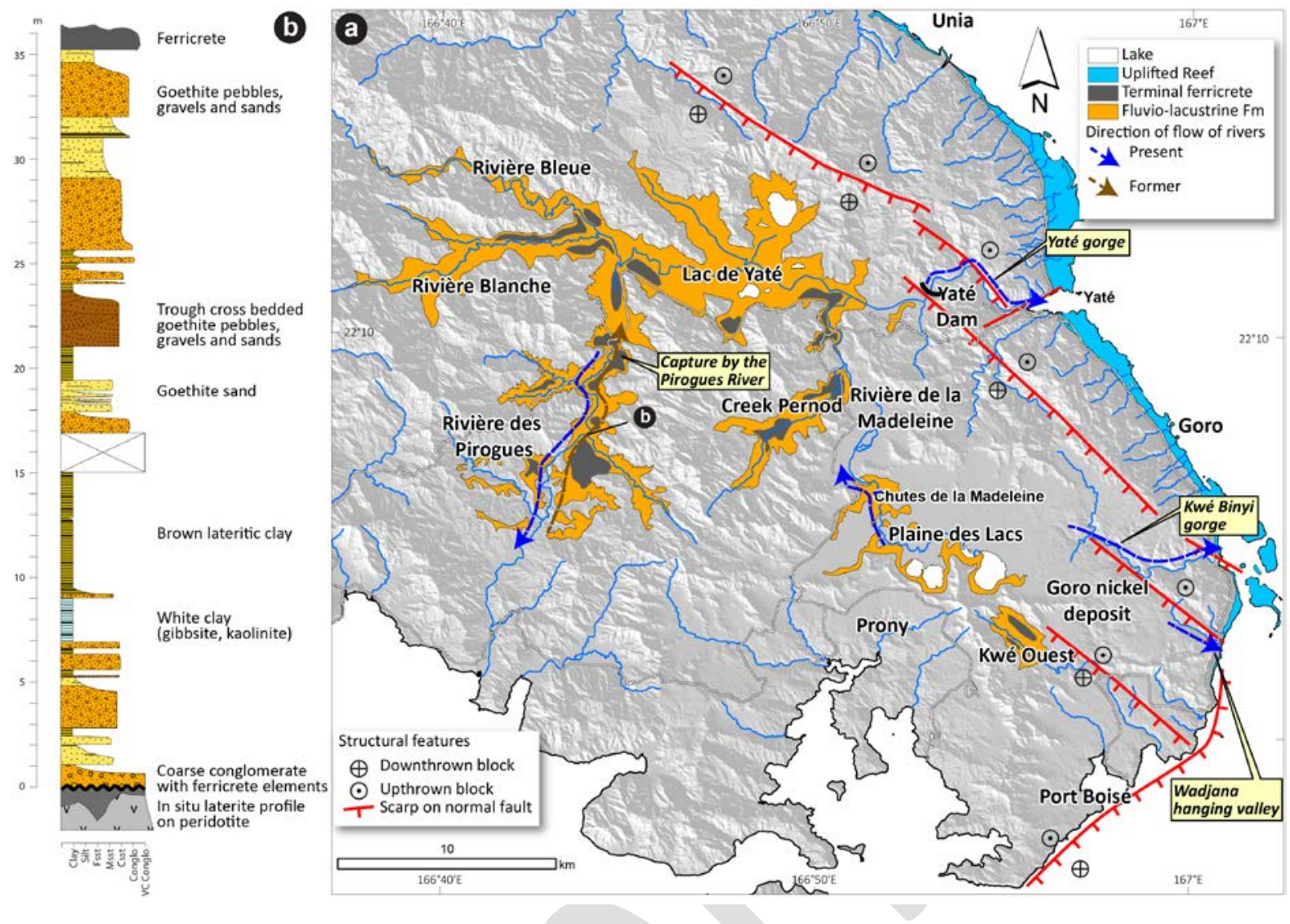

Fig. 19 a) Sketch map of the Fluvio-lacustrine Formation and some geomorphological features of the southeastern part of the Massif du Sud. The Yaté Lake reservoir has been removed to show the former sedimentary infill and the ancient topography. Brown and blue arrows indicate the direction of the ancient and present river flows respectively. b) Typical stratigraphic log of the deposits in the Rivière des Pirogues area (after Folcher 2016). 

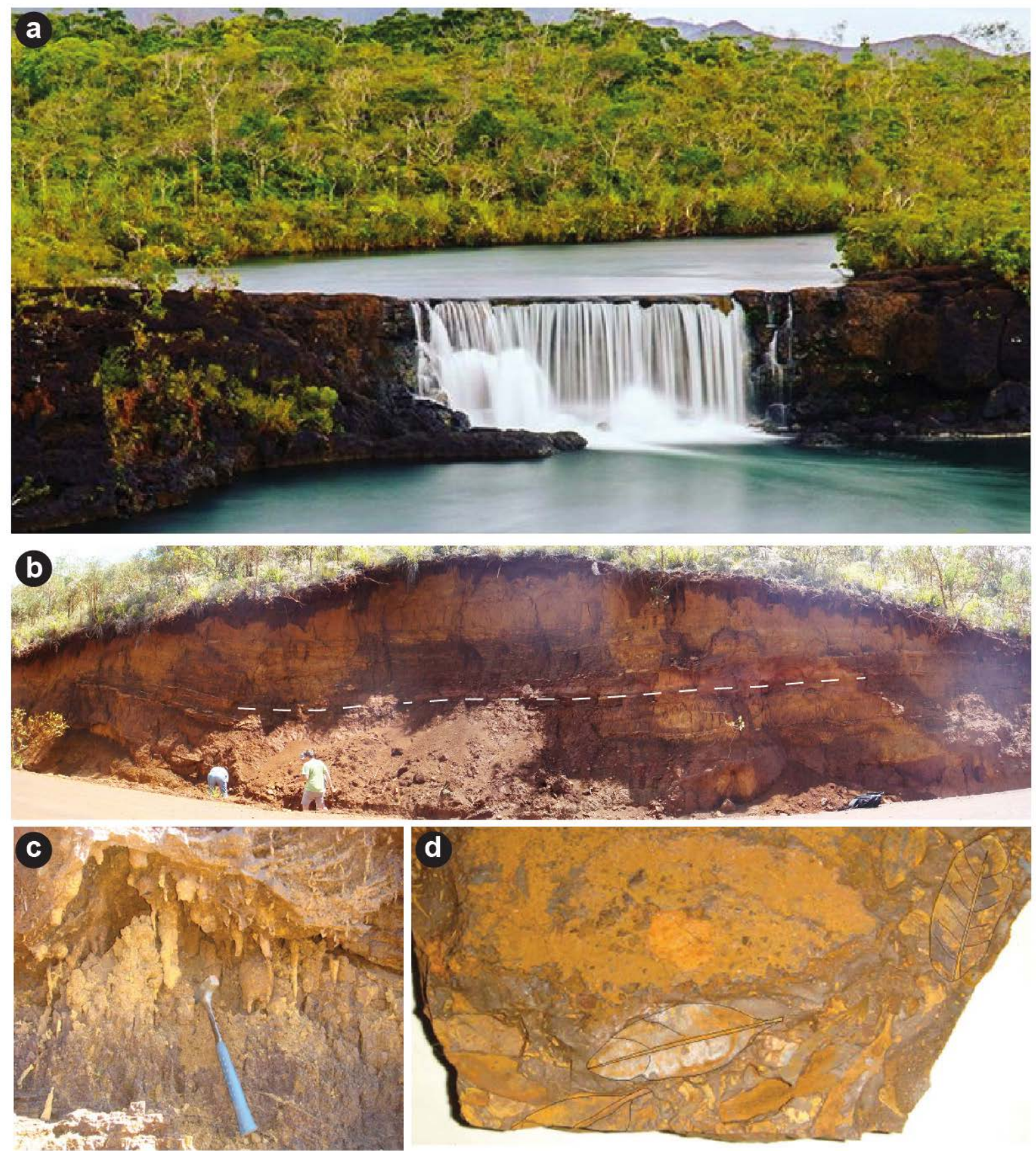

Fig. 20 Typical outcrops and rocks from the Fluvio-lacustrine formation. a) Chutes de la Madeleine (Madeleine Waterfall): a typical outcrop of the topmost ferricrete on top of the Fl-L Fm in the Plaine des Lacs; location on fig. 18. b) Road cut near Rivière des Pirogues. A layer of whitish clay (emphasised with white dashes) is visible half-way up the exposure. c) Ferrigenous rhizoconcretions. d) Fossil leaf imprints. 

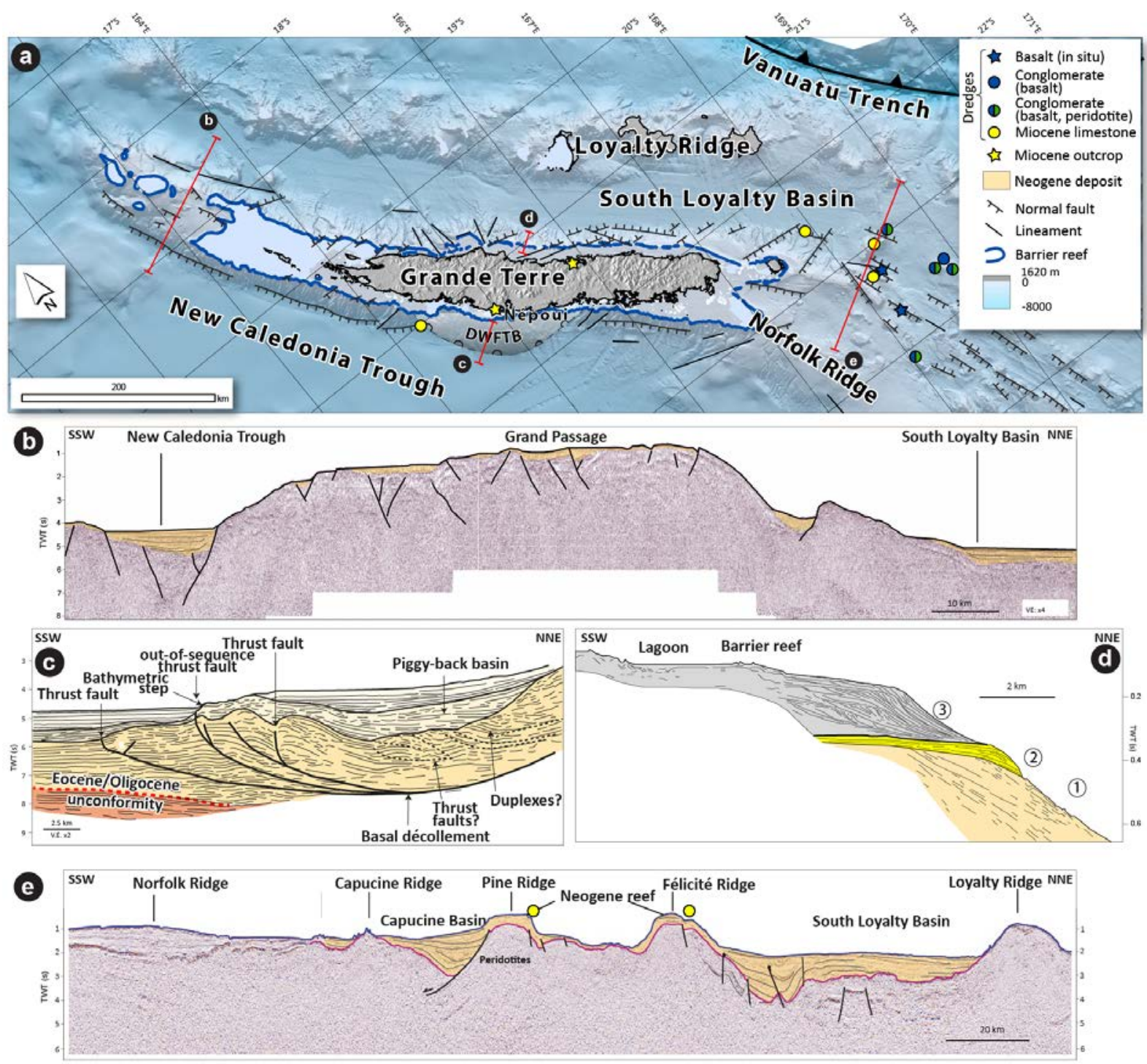

Fig. 21 Map of, and interpretations of seismic profiles through, the marine areas around Grande Terre (note different vertical and horizontal scales of sections. All profiles from the public Tasman Frontier Database (Sutherland et al. 2012). a) Map with main onshore outcrops and offshore dredges of Miocene rocks. b) Seismic profile across the northeastern extent of Grande Terre (line WNC117, modified after Lafoy et al. 1998). c) Seismic profile across the southwestern margin of Grande Terre showing the Deep Water Fold and Thrust Belt-like structure (line z1102, modified after Collot et al. 2017). d) Seismic profile across the north-eastern margin of Grande Terre (line NEOMARGES, modified after Chardon et al. 2008). 1) Miocene lower clastic wedge. 2) Miocene-Pliocene upper clastic unit covered by a lateritic palaeosurface. 3) Pliocene-Quaternary carbonate ramp (stars are indicating sub-unit progradation) grading westward into the Present Day rimmed carbonate platform. e) Seismic profile across the South Loyalty Basin, showing the development of Neogene and/or Quaternary carbonate platforms on top of structural ridges (offshore continuation of the New Caledonia ophiolite) and prominent normal faults (line s206-04, modified after Patriat et al. 2017). 


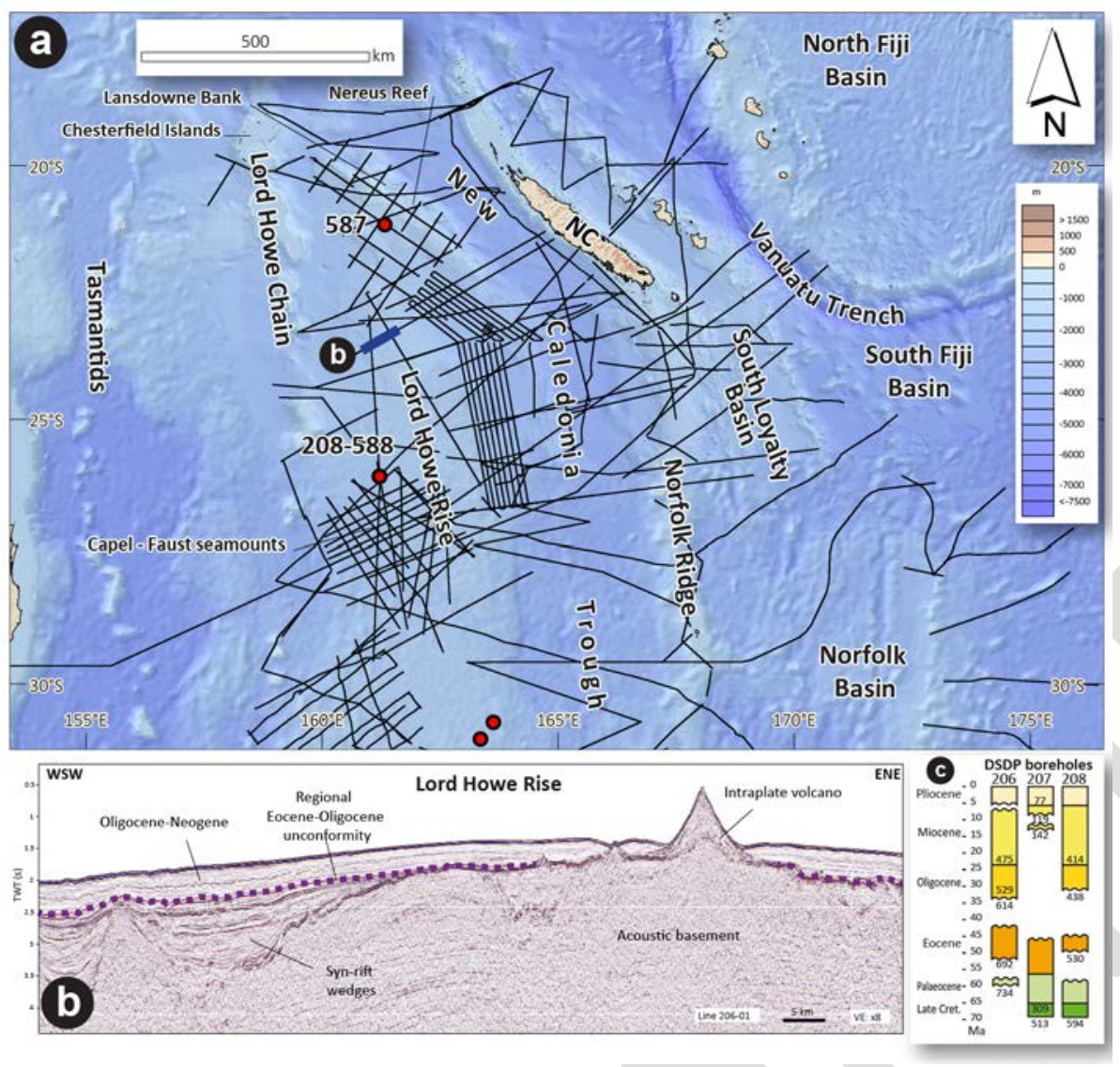

Fig. 22 a) Bathymetric map of Northern Zealandia (seismic lines from Tasman Frontier DataBase, Sutherland et al. 2012). b) Seismic profile 206-01 across the northern Lord Howe Rise, showing the overall continuous, thick and low amplitude seismic character of the Oligocene-Neogene succession together with an intraplate volcanic edifice. The Oligocene-Neogene rests on the regional EoceneOligocene unconformity and on the acoustic basement of the Lord Howe Rise. c) Diagram summarizing the DSDP well data (modified from Collot 2009) showing the prominent hiatus between the Eocene and Oligo-Neogene. 

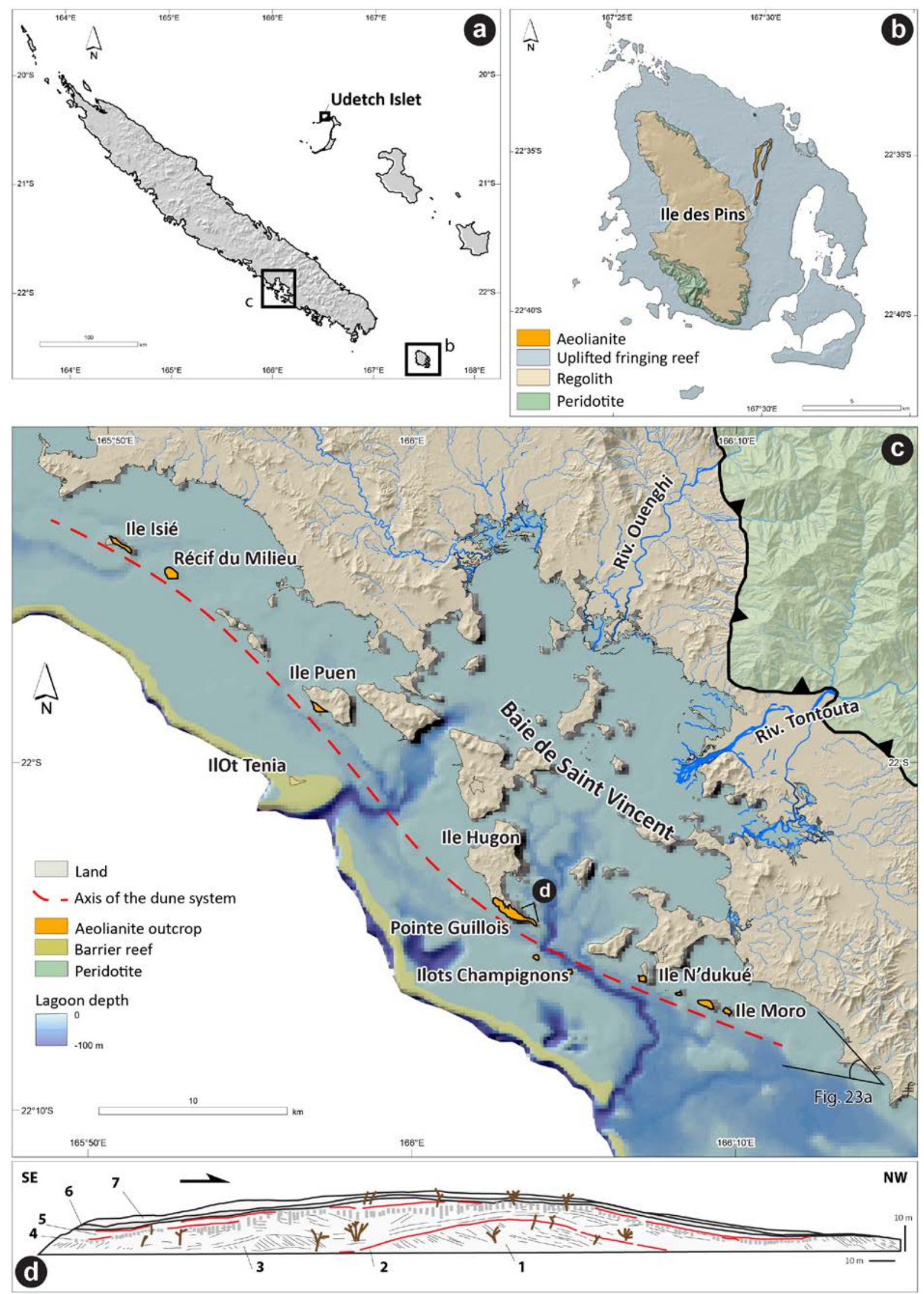

Fig. 23 Aeolianite occurrences in New Caledonia. b) on lle des Pins. c) around Baie de Saint Vincent; d) Sketch of aeolianite section at Pointe Guillois: 1) Lower dune (steep leeward beds); 2) Lower red horizon; 3) Upper dune (steep leeward beds then gently dipping winward beds); 4) Rhizocretion 
developed over 1, 2, and 3; 5) Upper red horizon; 6); Terminal calcrete; 7) Topographic surface capped by calcrete. Black arrow indicates direction of palaeo-wind projected onto the section. 

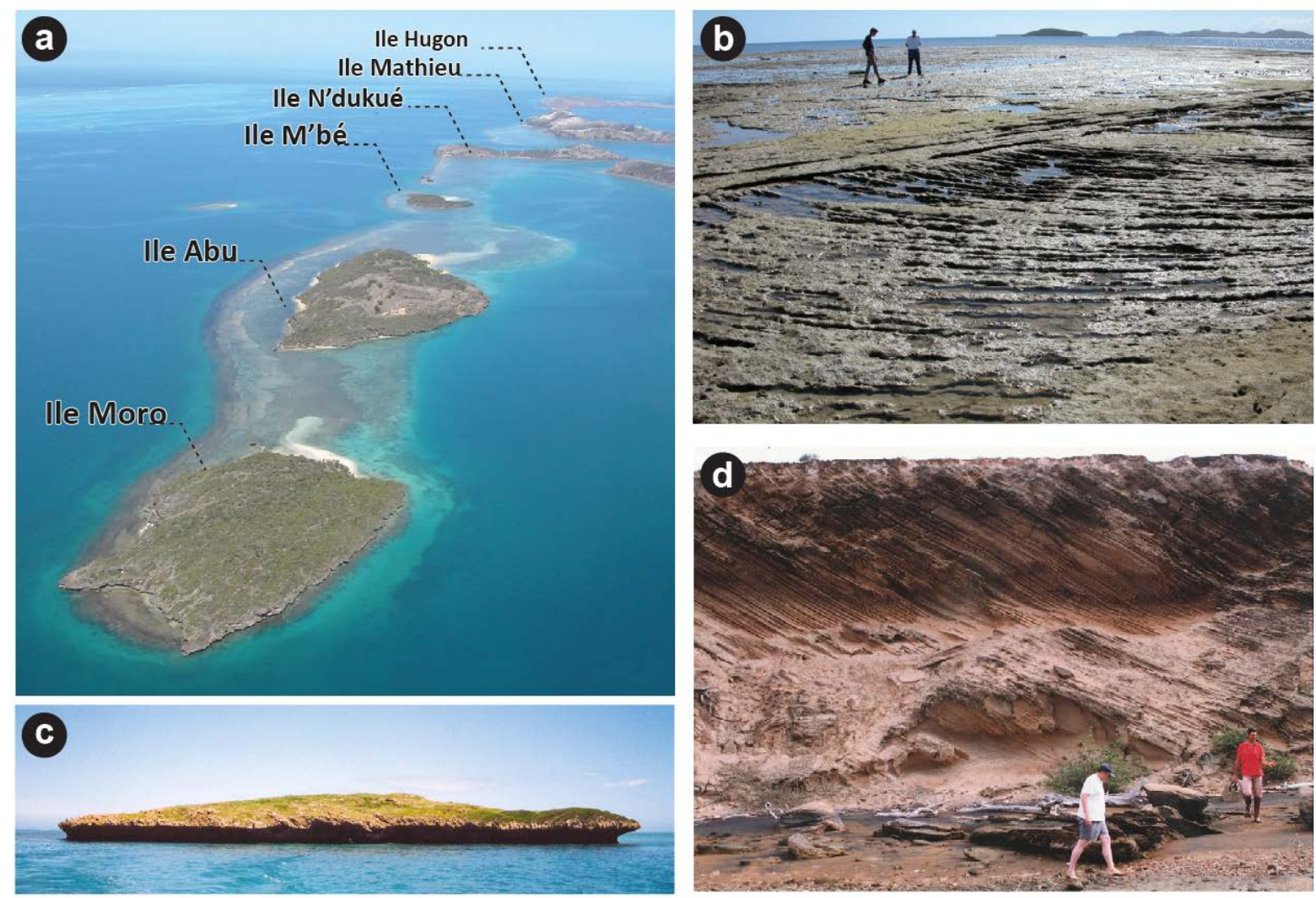

Fig. 24 Photo of aeolianite occurrences in Baie de Saint Vincent. a) Aerial view of the alignment of islands made of aeolianite corresponding to an ancient sand bar SW of Baie de Saint Vincent. b) Wave cut outcrop at Recif du Milieu. c) llot Champignon. d) Outcrop on lle Hugon. 


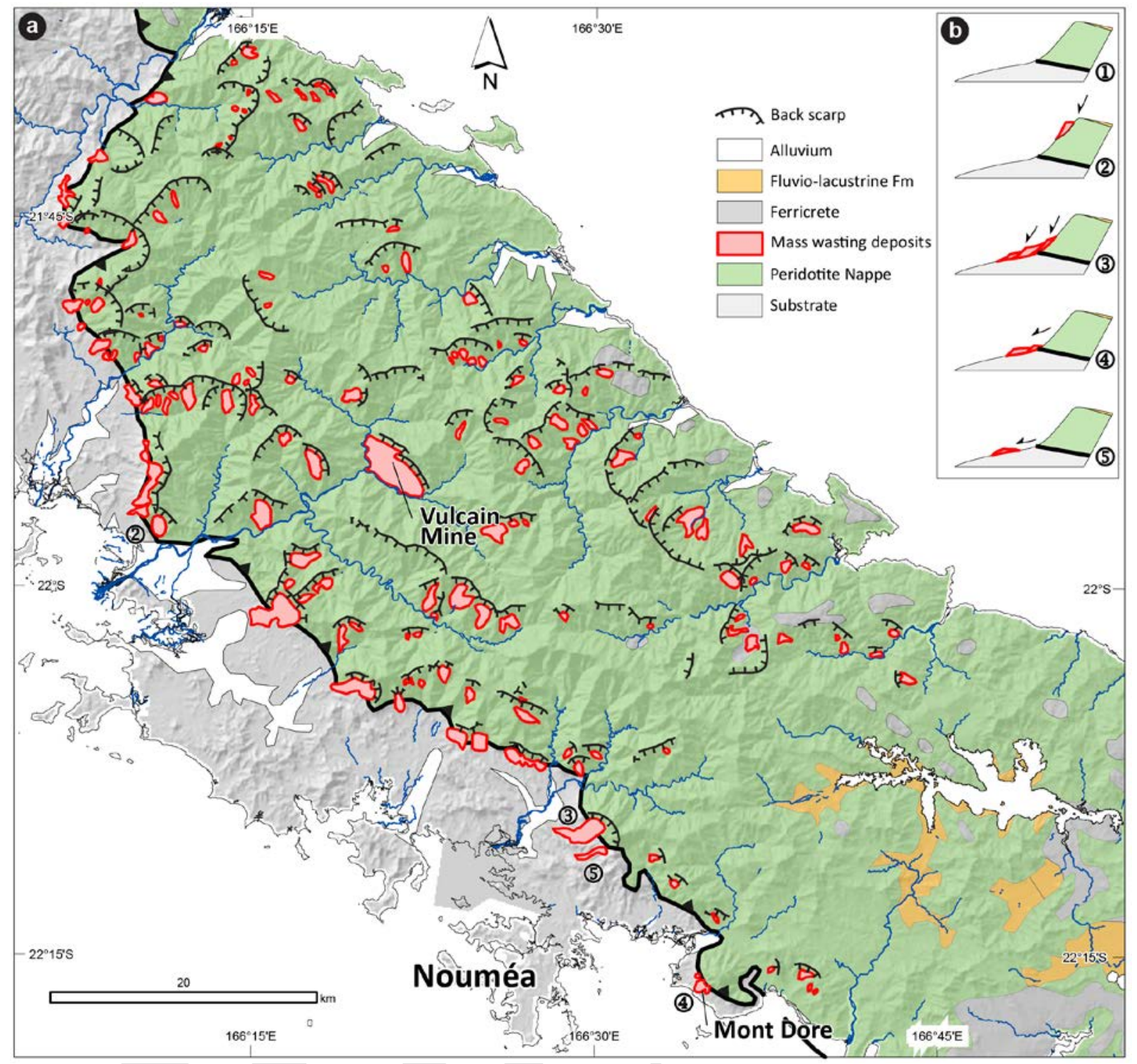

Fig. 25 a) Map of landslides in the mountainous area of the Massif du Sud (after Rouet (2009) and Maurizot et al. (2007). b) Schematic model of evolution (from top to base) of mass wasting at the front of the Massif du Sud. Circled numbers on the map refer to evolution stages on the sketch. 

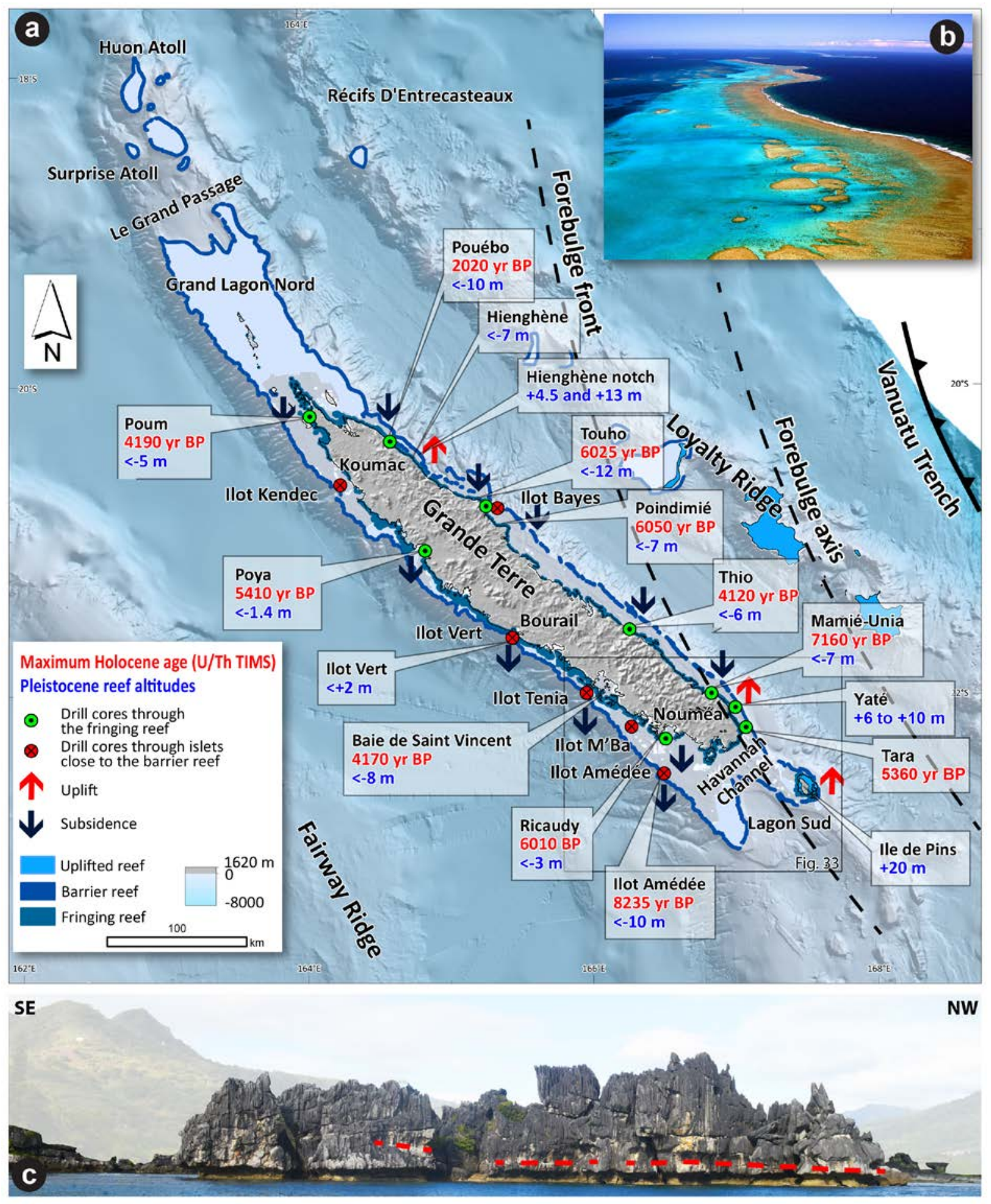

Fig. 26 a) The reef-rimmed shelf around Grande Terre after Andréfouët et al. (2009), Andréfouët \& Torres-Pullizza (2004) and www.ifrecor.nc. Labels indicate localities, Holocene age, and Late Pleistocene (125 ka) altitude, of reef (after Cabioch 2003). b) Aerial oblique view of the south western barrier reef; view from the NW of Boulari Pass and Amédée Islet. c) View from the lagoon of Palaeocene limestone lying along the coastline to the south of Hienghène showing the Present Day notch at sea level, and an older notch at 4-5 $\mathrm{m}$ above, dipping to the NW (red dashed line). 


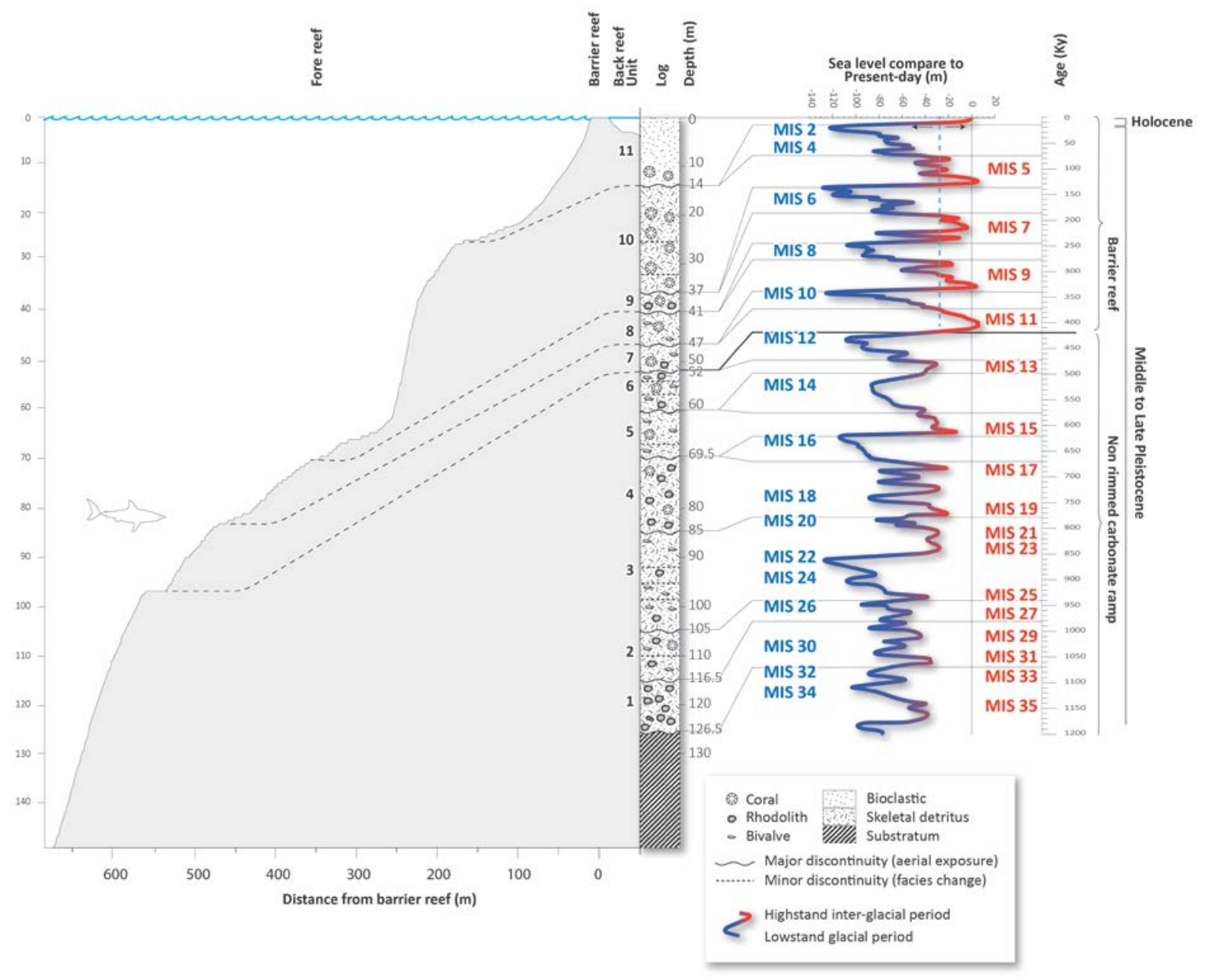

Fig. 27 Schematic log of the Amédée core (after Cabioch et al. 1999, Payri et al. 2004, Cabioch et al. 2008, Flamant 2006, Montaggioni et al. 2011) showing correlations with the relative sea level curve (Waelbroeck et al. 2002), Marine Isotopic Stages (MISs), and terrace depth on the fore-reef slope. 


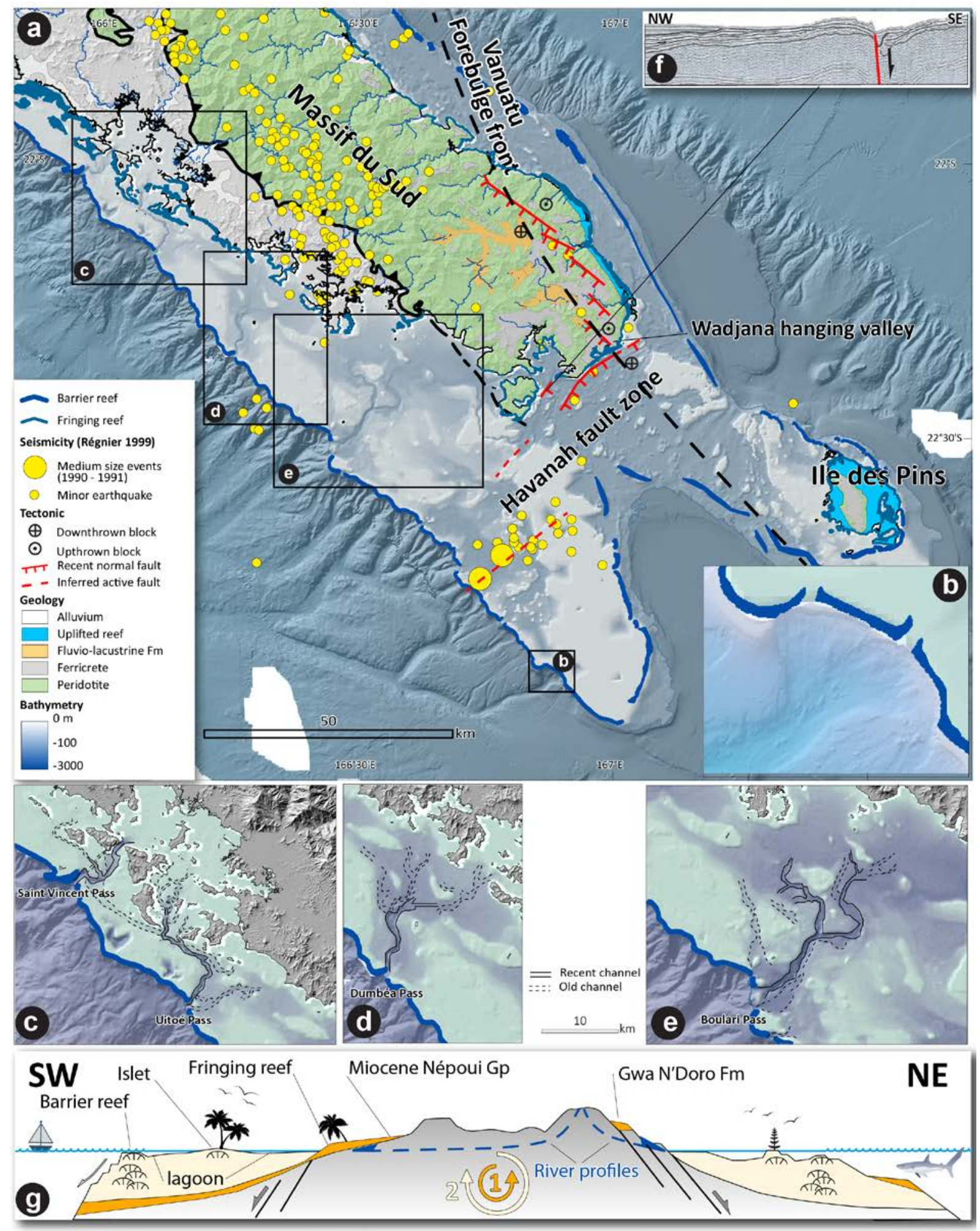

Fig. 28 Southern lagoon, barrier reef, and continental slope. a) Map with palaeo-rivers, recent and active faults, and seismicity. Seismicity after Régnier et al. (1999). Note the Havanah (normal) fault zone marking the southern end of Grande Terre. b) Detail of the south-western barrier reef showing a prominent scarp hanging over a deep canyon head prone to mass wasting. c) to e) Details of the south western lagoon showing flooded palaeo-rivers. f) Seismic line of Calgon survey (modified from Le Roy et al. 2008) showing a fault in the Holocene deposits of the lagoon. Note the alignment of earthquake epicentres delineating an active fault in the lagoon within the Havanah fault zone. g) 
Sketch cross section (no scale) showing the asymmetry of Grande Terre. 1) Orange arrow: Inland asymmetry of the Neogene formations, particularly Miocene deposits. 2) White arrow: Offshore asymmetry between the southwest and northeast lagoons. The southwestern lagoon is shallower, islets are wider, and the barrier reef is a large single tract where passes are narrow. The northeastern lagoon is deeper, the barrier reef is a double or triple tract, drowned, and passes are large. The southwestern fore-reef and continental slopes are generally steeper, with a high density of linear and concave submarine drainage profiles and conspicuous submarine landslide morphology. 


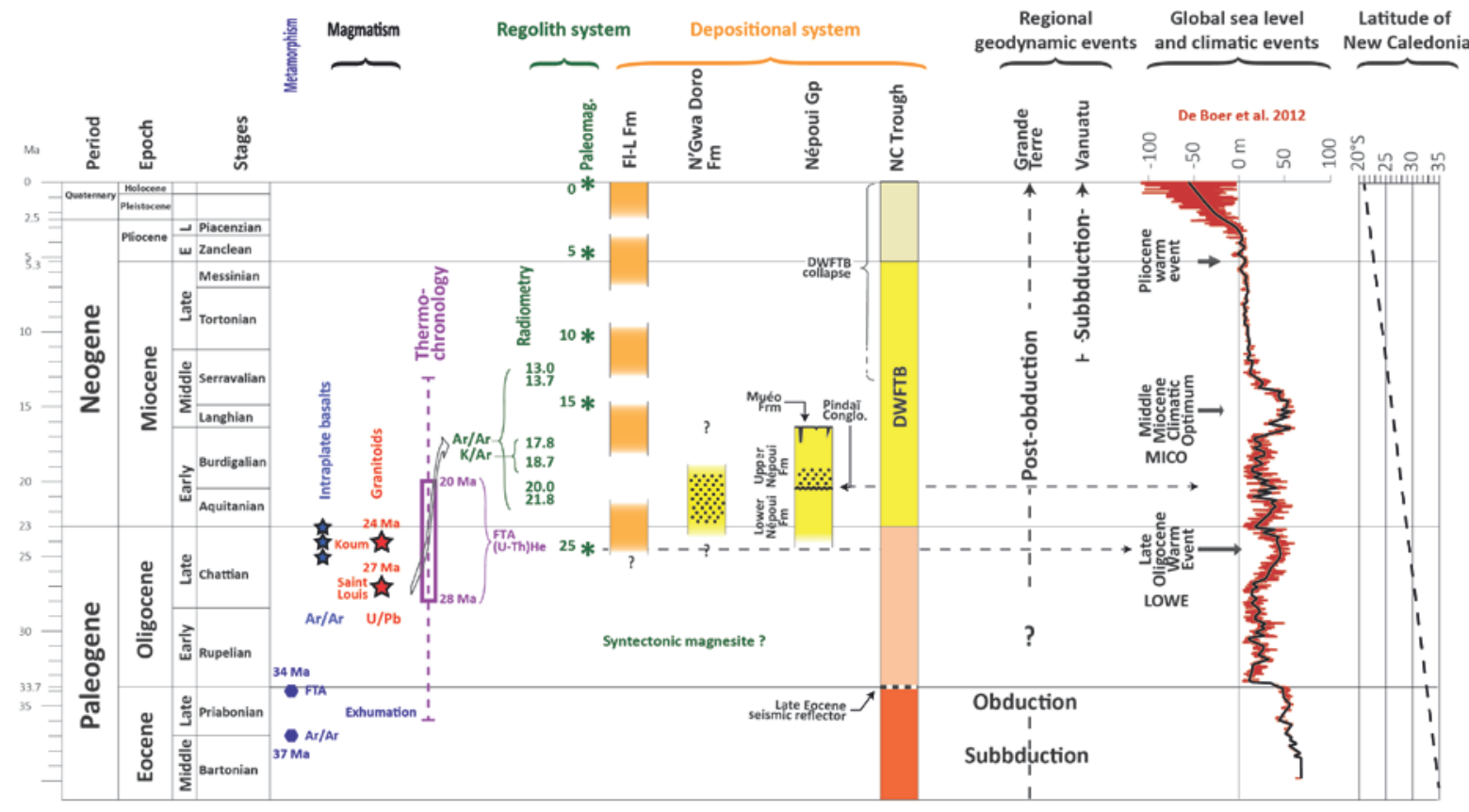

Fig. 29 Summary of post-obduction geological data including ages, regional geodynamic and climatic events. Global sea level curves according to De Boer et al. (2012). Mean palaeo-latitudes of New Caledonia, estimated by maps generated by GPlates (portal.gplates.org), and based on a hotspot reference frame, as in chapter 2 and 8 , this memoir. 


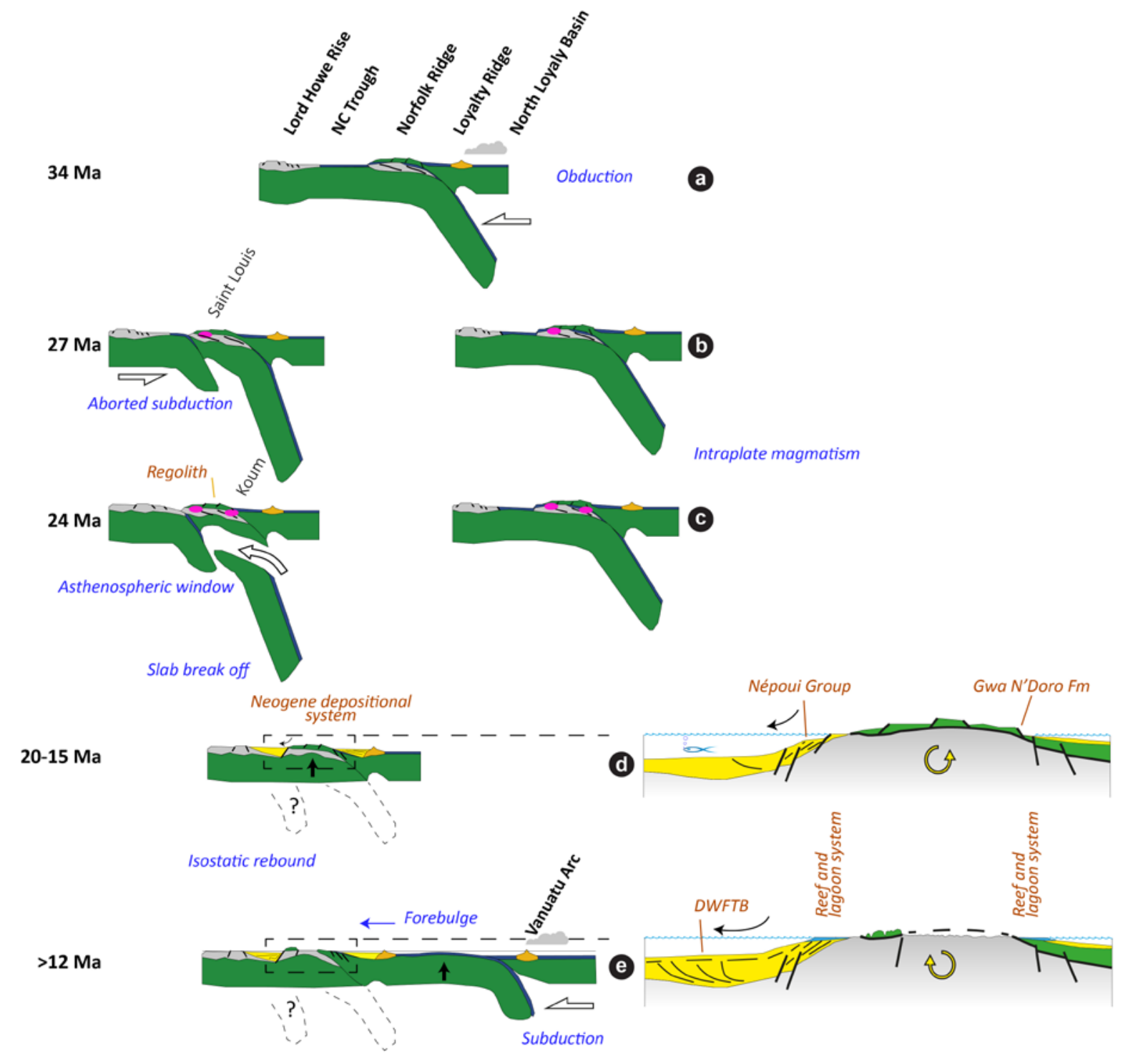

Fig. 30 Sketch reconstruction of the north eastern part of Zealandia from Oligocene to Present. 